\title{
Divine Comedies
}

\section{for the N E W \\ M I L L E N N I U M}

Recent DAN TE Translations

in AMERICA and THE NETHERLANDS

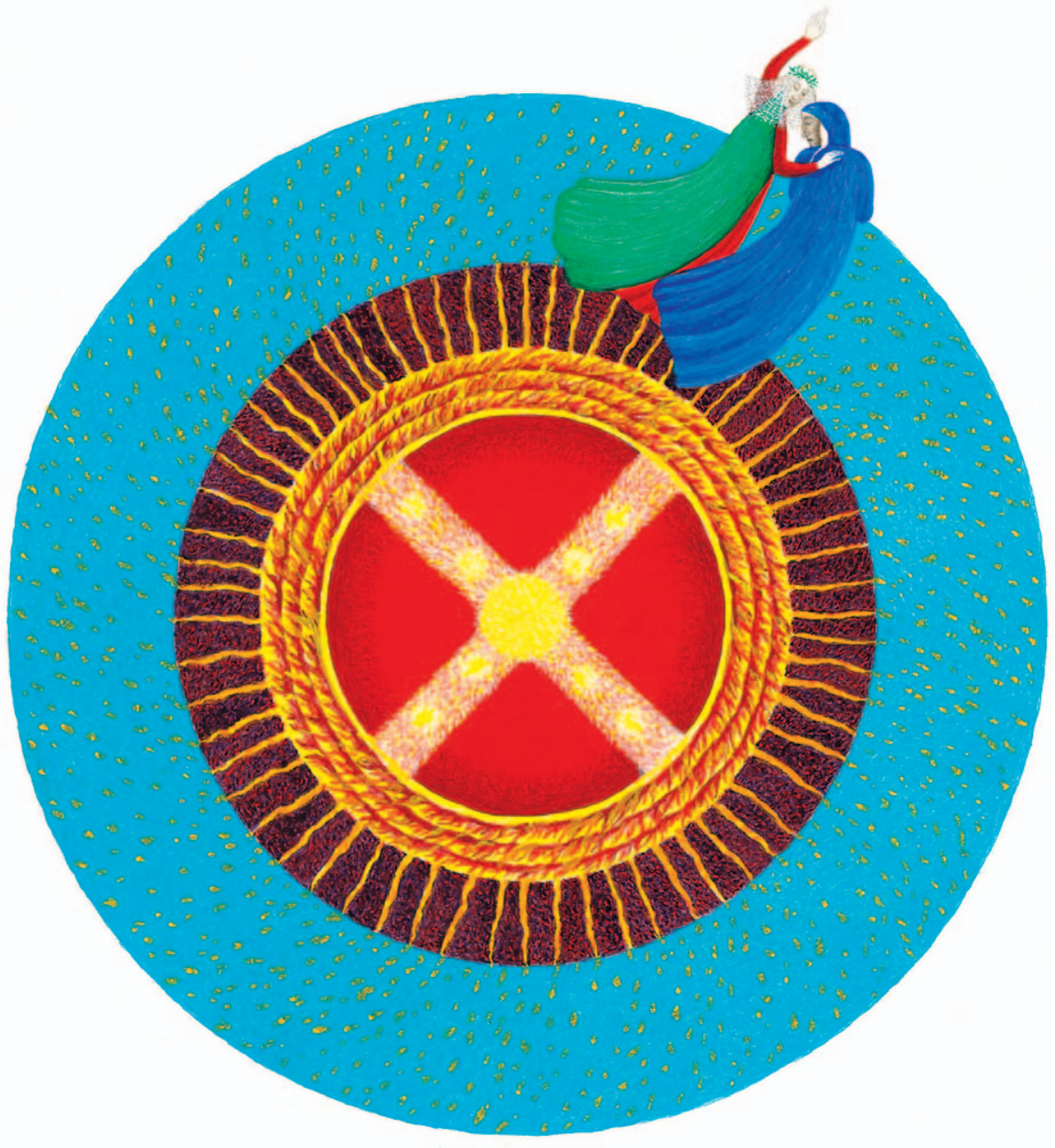

Edited by RONALD DE ROOY 
Divine Comedies for the New Millennium 



\section{Divine Comedies for the New Millennium}

Recent Dante Translations in America and the Netherlands

Edited by Ronald de Rooy

Amsterdam University Press 
With special thanks to the Istituto Italiano di Cultura per i Paesi Bassi (Amsterdam) and the Amsterdam committee of the Società Dante Alighieri for their financial contributions to the realization of this project.

Cover design: Studio Jan de Boer BNo, Amsterdam

Lay out: Paul Boyer, Amsterdam

Cover illustration: Paradiso 17. Dante and Beatrice are leaving the Heaven of Mars, where Dante has met his ancestor Cacciaguida. ( $15 \times 10 \mathrm{~cm})$

(C) Monika Beisner

All illustrations (C) Monika Beisner

ISBN 9053567325

NUR 630

(C) Amsterdam University Press, Amsterdam, 2003

All rights reserved. Without limiting the rights under copyright reserved above, no part of this book may be reproduced, stored in or introduced into a retrieval system, or transmitted, in any form or by any means (electronic, mechanical, photocopying, recording or otherwise) without the written permission of both the copyright owner and the author of the book. 


\section{Table of Contents}

INTRODUCTION

Ronald de Rooy Divine Comedies for the New Millennium.

Humbleness and Hubris

Paolo Cherchi The Translations of Dante's Comedy in America

Robert Hollander Translating Dante into English Again and Again

Jean Hollander

'Getting Just a Small Part of it Right'

Ronald de Rooy The Poet Translated by American Poets.

Paul van Heck

Ciò che potea la lingua nostra.

One Hundred and More Years of Dante Translations into Dutch

Pieter de Meijer

Translating Dante's Translations

IOI

NOTES

ABOUT THE CONTRIBUTORS

SELECTED BIBLIOGRAPHY OF AMERICAN AND DUTCH DANTE TRANSLATIONS

INDEX OF NAMES 



\section{Divine Comedies for the New Millennium. Humbleness and Hubris}

RONALD DE ROOY

\section{Dante in America...}

It was not that surprising that in the United States of America Dante's Divine Comedy received a lot of extra attention from translators in the years before the jubilee 2000, a 'magic' year because of the $700^{\text {th }}$ anniversary of Dante's voyage through the otherworld. America, of course, could already boast a strong tradition of Dante translations. At the beginning of the nineteenth century, the popular English Dante translation by Henry Francis Cary was an important instrument for introducing Dante in America. ${ }^{\mathrm{I}}$ The American tradition really began with Thomas William Parsons ${ }^{2}$ and continued with the first American 'dantisti' in Boston at Harvard College, reaching a first peak with the still famous translation published by Henry Wadsworth Longfellow in $1867 .{ }^{3}$ Since then, Dante has been translated into English 'again and again' (to quote the title of Robert Hollander's contribution to this volume), resulting in a steady flux of English canticles that seems to follow, someone once calculated, an almost biological rhythm: approximately every nine months a new English canticle is born, so to speak. ${ }^{4}$

What's more, this steady flow of 'Englished' Comedies has been accompanied from its very beginning by an extremely powerful and influential tradition of Dante studies. In the second half of the nineteenth century, Harvard College was a fertile breeding ground not only for Dante translations, but also for Dante studies: to remind us of the importance of this tradition, we need only mention famous scholars like Henry Wadsworth Longfellow, Charles Eliot Norton, James Russell Lowell, Charles Grandgent, and George Santayana. As is generally known, in the course of the twentieth century many other American scholars produced countless, truly indispensable contributions to the interpretation of Dante's works.

Apart from being repeatedly translated and eminently studied, Dante's Commedia has also been a steady and profound intertextual presence in AngloAmerican prose and poetry. Renowned and diverse twentieth-century authors and poets like Joseph Conrad, James Joyce, T.S. Eliot, Ezra Pound, W.H. Auden, Malcolm Lowry, Robert Lowell, Seamus Heaney, W.S. Merwin, Derek Walcott - to mention only a few of the better known names - have all been writing (and sometimes even living) for shorter or longer periods under Dante's spell. ${ }^{5}$

Dante's critical, creative, and translational fortuna in modern America has been, in one word, overwhelming. 


\section{$\ldots$ and in the Netherlands}

It is only logical that Dante's critical and literary reception has been much more small-scale and modest in a tiny country like the Netherlands. Throughout the nineteenth and twentieth centuries, the Netherlands has produced a reasonable number of Dante translations, but their total constitutes no more than approximately one-fifth of the overpowering Anglo-American production. It was surprising, however, that even the Netherlands with its modest tradition of Dante studies and translations experienced a genuine boom in Dante translations in the period around the year 2000. In fact, when adopting a specific and, I admit, slightly nationalistic point of view and focusing only on the period 1996-2003, we see a kind of balance between the number of Dante translations in the huge USA and that in the tiny Netherlands.

In these years around 2000, in fact, no less than seven canticles were published in Dutch (i.e. two entire Comedies and one Inferno) versus nine canticles in English (i.e. one entire Comedy, four Inferno's, and two Purgatorio's). The table below contains all Dante translations in the USA and in the Netherlands in the last twenty years:

\begin{tabular}{|c|c|c|c|c|}
\hline & USA & canticles & Netherlands & canticles \\
\hline 1971-1981 & Mark Musa & 3 & & \\
\hline 1980-1982 & Allen Mandelbaum & 3 & & \\
\hline 1980 & C. H. Sisson & 3 & & \\
\hline 1985 & Nicholas Kilmer [Inf.] & 1 & & \\
\hline 1985 & Tom Phillips [Inf.] & 1 & & \\
\hline 1987 & James Finn Cotter & 3 & Frans van Dooren & 3 \\
\hline 1994 & $\begin{array}{l}\text { Steve Ellis }[\operatorname{Inf} .] \\
\text { Robert Pinsky }[\operatorname{Inf} .] \\
\text { James Torrens }[\text { Par. }]\end{array}$ & 3 & & \\
\hline 1996 & $\begin{array}{l}\text { Peter Dale } \\
\text { Robert Durling [Inf.] }\end{array}$ & 4 & & \\
\hline 1998 & Elio Zappulla [Inf.] & 1 & & \\
\hline 1999 & & & Jacques Janssen [Inf.] & 1 \\
\hline 2000 & $\begin{array}{l}\text { W.S. Merwin [Purg.] } \\
\text { Robert \& Jean } \\
\text { Hollander [Inf.] }\end{array}$ & 2 & $\begin{array}{l}\text { Ike Cialona \& Peter } \\
\text { Verstegen } \\
\text { Rob Brouwer [Inf.] }\end{array}$ & 4 \\
\hline 2001 & & 1 & Rob Brouwer [Purg.] & 1 \\
\hline 2002 & $\begin{array}{l}\text { Michael Palma }[\operatorname{Inf} .] \\
\text { Anthony Esolen }[\operatorname{Inf} .]\end{array}$ & 2 & Rob Brouwer [Par.] & 1 \\
\hline 2003 & $\begin{array}{l}\text { Robert \& Jean } \\
\text { Hollander [Purg. }] \\
\text { Robert Durling [Purg. }]\end{array}$ & 2 & & \\
\hline 1996-2002 & & $\begin{array}{l}\text { (10) } \\
6 \text { Inf. } \\
2 \text { Purg. } \\
2 \text { Par. }\end{array}$ & & $\begin{array}{l}\text { (7) } \\
3 \text { Inf. } \\
2 \text { Purg. } \\
2 \text { Par. }\end{array}$ \\
\hline
\end{tabular}


As is clear from this table, ${ }^{6}$ in the last six years (1996-2002) the numerical difference between the USA and the Netherlands has suddenly become very small: the USA 'prevails' by merely three Inferno's. However, if we do not include the translation of the entire Comedy published by the English poet Peter Dale, the Netherlands and the USA draw even at 7 to 7.

Of course, as becomes equally clear from the upper rows in the same table, this kind of mathematics will only work in a very short period around the year 2000, but it shows nonetheless how incredibly flourishing the most recent years have been for Dutch Dante translations. While the American increase of Dante translations around year 2000 constituted no more than a slight increase in a long and already productive tradition, in the Netherlands we truly witnessed an upsurge of Dante's fortuna.

This fortunate and historic moment in Dutch Dante studies, unique in the whole world, gave rise to a seminar about the recent Dante translations in the USA and in the Netherlands. It seemed important to record this historic moment somehow before the USA would inevitably take back its control of the situation. ${ }^{7}$ This seminar was an interesting opportunity for American and Dutch Italianists to compare the twentieth-century traditions of Dante translations in these two nations and to present several critical and comparative analyses of the most recent American and Dutch translations. The results have been brought together in this volume.

The contributions of Paolo Cherchi and Paul van Heck offer valuable insight into the history of American and Dutch Dante translations. For the USA, Paolo Cherchi discusses the most important highlights of Dante's American 'pilgrimage', from the first American translator, the dentist Thomas William Parsons, up to one of the most recent, the 'poet laureate' Robert Pinsky. Cherchi pays due attention to the older translations as well, because several of them are still significant reference points for modern translators. Cherchi discusses the merits of the famous Dante translation by Henry Wadsworth Longfellow, whose Inferno has very recently been reprinted. ${ }^{8}$ Particularly, he compares some beautiful Paradiso excerpts from Longfellow's version with the first important prose translation by Charles Eliot Norton. Roughly speaking, the first half of the twentieth century is dominated by various translational experiments, and by the slow transition from a RomanticVictorian perspective on translating to a more 'formalistic' concept and approach. The modernist poets T.S. Eliot and Ezra Pound played a key role in this process towards a formalist aesthetic. A real achievement in this context was John Ciardi's 'transposition' of Dante's Comedy, a recreation in which the translator tries to convey some idea of the living language of the original text. Cherchi's chapter also focusses on the most influential translations from the last fifty years - especially those by Charles Singleton, Mark Musa, Allen Mandelbaum, and Robert Pinsky thus compensating for the shortage of studies about this period. 
For the Netherlands, Paul van Heck has described the history of all Dutch translations of the Comedy, a tradition which up to now comprises fifteen entire Comedies and three Inferno's. In one of the appendices of his article, Van Heck has brought together eighteen different Dutch versions of the famous simile of the peasant and the fireflies with which Dante conveys his first visual impression of the bolgia of the false counselors (Inf. 26, 25-33). Van Heck's important survey of the eighteen translations of Dante's Comedy focuses especially on their translational strategies, but interestingly also on many of their paratextual aspects: the number of volumes and pages, the format of the book, the number of its editions, the aesthetic quality of the edition, and the scholarly quality of the edition (which, among other things, can be measured by the presence or absence of the Italian text, the presence or absence of a foreword, a general introduction, an afterword, the extent and depth of the commentary, etc.). With this last analysis, Van Heck demonstrates that an 'accurate description of the paratext amounts to a description of the way a text presents itself in literary society and of the welcome it receives'. In the final part of his article, Van Heck takes the reader round a portrait gallery, showing especially the completely forgotten makers of some of these Dutch Dante translations.

The other four articles in this volume focus primarily on the characteristics and qualities of the most recent Dante translations. Paolo Cherchi ends his American chronological survey by merely referring to one of the most interesting American Dante projects in recent years, namely the free verse translation by Robert and Jean Hollander.

In this volume, both Robert and Jean Hollander share their views on translating Dante in general and on their own translation in particular. The Hollanders' translation was born out of a collaboration between a renowned scientist and a gifted poetess, 'the fruit of wedding Philology with Poetry,' as Paolo Cherchi put it. The project started as a revision and modernization by Robert Hollander of the prose translation by John D. Sinclair,9 a new version that he needed for his prestigious Princeton Dante Project, one of the major Dante sites on the Internet. ${ }^{10}$ One day Jean was looking over her husband's shoulder at what he was doing, and her judgment was devastating: 'What is it? It's awful,' she said. According to Jean, this text was nothing less than 'unsayable', non-poetical to the degree of being literally unspeakable. Within two days, Jean transformed the first Sinclair-Hollander canto into a poetical text, and that is how their fruitful collaboration began: Robert Hollander took responsibility for the accuracy of the translation, and Jean Hollander had to make sure that 'it sounds like English verse'. The note that precedes Robert Hollander's scholarly introduction reads like a sort of confession in which the Hollanders are extremely clear about their translational strategy and about the goals of their translation: 
'Reader, this is an honest book,' Montaigne says this of his Essays. We would like to say the same of this translation. We have tried to bring Dante into our English without being led into the temptation of making the translation sound better than the original allows. $^{\text {II }}$

The two translators, who strike a very modest attitude towards Dante's text, invite their readers to form an opinion about their translation by comparing it to the original that is printed, and that is how it ought to be, a fronte:

The result may be judged by all who know him in his own idiom. This is not Dante, but an approximation of what he might authorize had he been looking over our shoulders, listening to our at times ferocious arguments. We could go on improving this effort as long as we live. We hope that as much as we have accomplished will find an understanding ear and heart among those who know the real thing. Every translation begins and ends in failure. To the degree that we have been able to preserve some of the beauty and power of the original, we have failed the less. ${ }^{\mathrm{I} 2}$

The couple is very honest in expressing their at times great debt towards the prose translation by John D. Sinclair, and finally they are very clear about the aim of their efforts:

Our goal has been to offer a clear translation, even of unclear passages. We have also tried to be as compact as possible - not an easy task, either. It is our hope that the reader will find this translation a helpful bridge to the untranslatable magnificence of Dante's poem. ${ }^{\mathrm{I3}}$

They also have a similar crystal-clear opinion as to their choice of expressive means: in a chat published on the Internet, they say they avoided a rhyming or terza rima translation because according to them the contents of the original should prevail:

We find that the loss that occurs in finding rhymes so forces the sense that it is better to surrender on that front and try to be most faithful to the shadings of sense in the original. People disagree about this, but that is where we stand. ${ }^{14}$

Nonetheless, it is remarkable that many recent American translations are made by poets and writers. It is even more remarkable that many recent translations by poets are written in Dante's original metre, the famous terza rima, which is notorious for its untranslatability. I will focus on this 'poetical' category of modern American Dante translations, and in particular on the poets/translators Robert Pinsky, Richard Wilbur, Peter Dale and Michael Palma in my own contribution to this volume. 
In the Netherlands, on the other hand, poets and writers do not play an important role in modern Dante translations. The last poet to have translated the Comedy in rhyming tercets in Dutch was Albert Verwey, and this translation dates back to $1923 .{ }^{15}$ The makers of the twentieth-century Dutch Comedies are mostly teachers of the classics, priests, and professional translators. In his contribution about the most recent Dutch translations, Pieter de Meijer focuses on a kind of 'mise en abyme'-effect: translators of the Divine Comedy are, in fact, translating the text of a poet who has already proved to be an excellent translator in his own right. In the Divine Comedy, Dante frequently translates for example some of his classics, the Bible, or liturgical texts. In analyzing how the most recent Dutch translators - Jacques Janssen, Rob Brouwer, Ike Cialona and Peter Verstegen have dealt with this specific aspect, De Meijer manages to bring out some of the essential merits but also some imperfections of their translations.

\section{Newcomers on a Crowded Stage}

The American and Dutch Divine Comedies discussed in this volume are first of all important landmarks in two different traditions of making Dante's work accessible to non-Italian readers. At the same time, however, they are not intended exclusively as a mere slip road to Dante's masterpiece: these translations were made when numerous others were already available in Dutch and English. Therefore, on this already crowded stage every newcomer inevitably makes (direct or indirect) statements about how Dante's masterpiece should be read: as a poem, as a scholarly or philosophical treatise, or as a learned philosophical poem? Regardless of the translators' intentions, it is necessary and illuminating to analyze and compare the effective results of these translations with regard to semantic faithfulness, tone and poeticality, in order to get some idea as to the directions in which the American and Dutch traditions are moving.

As we will see in the course of this volume, the already mentioned numerical equilibrium between the USA and the Netherlands is also reflected in a series of similar choices from the spectrum of possible translational strategies by American and Dutch translators, and in similar developments and trends. Roughly speaking, there seems to be a tendency from soberly 'colloquial' or soberly 'academic' prose translations (say the Inferno by Robert Durling in the USA and that by Jacques Janssen in the Netherlands) towards more poetical translations in free or blank verse, and also in terza rima.

As regards prose translations, it should be remembered that in the last three decades of the twentieth century there were several very popular and successful prose translations. In particular, we must mention the famous American version by Charles Singleton (1970-1975) ${ }^{16}$ and the extremely popular Dutch version by Frans van Dooren (1987). ${ }^{17}$ It is interesting to note, however, that these two prose 
versions form exact opposites in their translational strategy. Singleton adopts a sober, simple and literal style throughout his whole Comedy, thus giving the maximum priority to his thorough scholarly commentary and, paradoxically, to the Italian original that is printed a fronte. Van Dooren, on the other hand, constantly tends towards a more paraphrastic translation, 'filling in' the blanks and illuminating the dark spots of Dante's text. ${ }^{18}$

Judging from the most recent translations in the USA and the Netherlands, however, prose seems to have become somewhat outdated. It is significant in this respect that the most recent prose translators, Robert Durling and Jacques Janssen, seem to cover up their use of prose by using a rather effective and more poetical lay out in which one tercet of the original corresponds to one paragraph in the translation.

Among the recent poetical translations, we can distinguish between (I) essentially poetical and 'creative' translations, are often in terza rima, and (2) free or blank verse translations that try to strike a happy medium between poeticality and semantic faithfulness.

Among recent poetical and 'creative' translations we should mention at least those by Robert Pinsky (1994), Peter Dale (1996), W.S. Merwin (2000), and Michael Palma (2002) in the USA, ${ }^{19}$ and in the Netherlands that by Ike Cialona and Peter Verstegen (2000). ${ }^{20}$

The most significant recent free verse translation is certainly that by Robert and Jean Hollander (Inferno 2000, Purgatorio 2003), ${ }^{21}$ while Rob Brouwer (Inferno 2000, Purgatorio 200I, Paradiso 2002) has enriched the Netherlands with a beautiful blank verse translation. ${ }^{22}$

\section{From Cautious to Courageous}

W.S. Merwin has asserted that every single translation of Dante's Comedy 'had a dimension of impossibility'. ${ }^{23}$ Strictly speaking, the Comedy is untranslatable, and this might very well be the main reason why the flow of new Dante translations never stops. On the other hand, it seems that Dante translations have reached some kind of crossroads, at which every new translator has to make an important and decisive choice. The old polarization between the fearless (at times reckless) 'poetical' translators and the more cautious 'academic' translators seems to be very much alive. As I have said before, prose translations, although still popular in the I970s and 1980s, seem to have become outdated. Now the choice is rather between compromise or confrontation, between caution and courage, between free or blank verse and rhyming verse. And there certainly seems to be a mysterious pressure on present-day translators to follow Dante's footsteps more closely, rhyming like he does, repeating his miracle.

We could compare this situation to the delicate moment in Dante's story of Ulisse, when the courageous voyager hero tries to convince his loyal but more 
cautious companions to move on, to explore the unknown, to try new ways... Ulisse could in this respect be seen as a figure of the fearless terza rima translator, while his hesitant companions and Dante himself might be seen as the more cautious and often more modest verse translators. Dante has immortalized this moment of choice in the three famous tercets of Ulisse's passionate plea:

'O frati,' dissi, 'che per cento milia perigli siete giunti a l'occidente, a questa tanto picciola vigilia

d'i nostri sensi ch'è del rimanente non vogliate negar l'esperïenza, di retro al sol, del mondo sanza gente.

Considerate la vostra semenza:

fatti non foste a viver come bruti, ma per seguir virtute e canoscenza.'

(Inf. 26, II2-I2O) [Ill. 4, Inferno 26]

In the remainder of this introduction, I will examine several American and Dutch translations of this superb fragment. This survey will allow me to introduce briefly the most important stylistic characteristics of these Divine Comedies for the new millennium, and at the same time it will serve as an illustration of a clear tendency from cautious prose to free or blank verse, and from free or blank verse to courageous terza rima.

\section{Prose: Robert Durling, Jacques Janssen}

Robert Durling translates Ulisse's plea certainly not poetically, but soberly and above all very faithfully, as follows:

'O brothers,' I said, 'who through a hundred thousand perils have reached the west, to this so brief vigil

of our senses that remains, do not deny the experience, following the sun, of the world without people.

Consider your sowing: you were not made to live like brutes, but to follow virtue and knowledge.' 24 
Because of its literal rendering of the original text, this is a perfect translation for students of Italian literature who use the translation as a means of understanding and appreciating more fully the original Italian text. Durling's Dutch counterpart, Jacques Janssen, states that he uses in his prose translation a colloquial and direct style, which can and should be read aloud:

\author{
'Broeders', zei ik, 'aan honderdduizend \\ gevaren zijn wij ontsnapt op onze tocht naar \\ het westen. Ik hoop dat de korte tijd die nog \\ rest, ons er niet van zal weerhouden \\ op onze reis naar de zon kennis te \\ maken met de onbewoonde wereld. \\ Besef goed waar je van afstamt. Jullie \\ zijn niet gemaakt om te leven als beesten, \\ maar om te streven naar deugd en kennis. ${ }^{25}$
}

Janssen's version is certainly colloquial and direct, but it is also a little less literal and accurate. Consider that in this fragment Ulisse makes his voyage 'to the west', when in reality he actually has arrived already 'a l'occidente', 'at the west', i.e. at the end of the known Western world. 'The brief vigil of our senses that remains' has become in Janssen's version, more directly, 'de korte tijd die nog rest' ('the short time that remains'). One also misses in Janssen's translation the rhetorically extremely efficient double negation of Ulisse's speech, 'non vogliate negar...'. While Durling is a specialist of Italian Trecento literature who translates Dante with philological accuracy, Janssen is a professor of Cultural and Religious Psychology with a deeply felt passion for Dante who aims at a direct and, above all, highly readable translation. While Durling's sober and serious translation (like Singleton's) is of use in classrooms where Dante is taught, Janssen's version succeeds in bringing Dante to a much broader reading public, especially because it also contains a very inspiring overview of Dante illustrations, from fourteenthcentury illuminations up to late-twentieth-century artwork. Both Durling and Janssen clearly share the view of the Comedy as a scholarly text, which needs straightening out and explaining. In fact, they both dedicate much space to an equally interesting, vivid and modern commentary.

\title{
2. Verse: Robert and Jean Hollander, Rob Brouwer
}

Let us now look at the same crucial passage of Ulisse's story in the most important blank verse renderings, for the USA Robert and Jean Hollander (2000), and for the Netherlands Rob Brouwer (2000): 
'O brothers,' I said, 'who, in the course

of a hundred thousand perils, at last

have reached the west, to such brief wakefulness

'of our senses as remains to us,

do not deny yourselves the chance to know -

following the sun - the world where no one lives.

'Consider how your souls were sown:

you were not made to live like brutes or beasts,

but to pursue virtue and knowledge.'26

Rob Brouwer:

'Mijn broeders, die gevaren zonder tal doorstaan hebt op de tocht naar 't Westen,' zei ik, 'wil niet de korte wake die nog rest

aan jullie leven, 't zingenot misgunnen

een wereld te ervaren vér voorbij

de zon, een wijde wereld zonder mensen.

Bedenk te zijn verwekt niet voor 'n bestaan van redeloze dieren, maar teneinde

slechts achter deugd en kennis aan te gaan.'27

Of these two non-rhyming verse translations, Brouwer's has a more regular rhythm and meter, which consists of an alternation of decasyllables with masculine endings and hendecasyllables with feminine endings. While not following such a severe metric structure, the Hollanders' translation is nonetheless very rhythmic and musical. In combination with their moderate translation strategy, both the Hollanders and Brouwer purport to offer an honest and above all reliable rendering of Dante's text, which also respects its important poetical qualities. They both decided not to try a rhyming translation - in fact, in this volume both Jean and Robert Hollander present a very strong case against any rhyming Dante translation - because of the many semantic sacrifices that such a strategy would inevitably entail. Brouwer's version has Dantean compactness and 'strangeness', and it compensates the loss of rhyme by meter and, for example, also by adding several euphonious alliterations (cf. 'een wereld te ervaren $v$ ér $v$ oorbij / de zon, een wijde wereld zonder mensen'). 
Both translations have in common a wealth of explanatory and scientific notes, numerous glosses, comments, and introductions. In the case of the Hollanders' translation of the Inferno, the commentary fills almost nine pages for every single canto, while the list of cited works at the end of the book is over thirty pages long.

\section{Terza rima: Robert Pinsky (1994), Michael Palma (2002), Ike Cialona and Peter Verstegen (2000)}

At the end of the spectrum, we find several recent renderings in terza rima, a translational strategy that in the last years of the twentieth century was quite suddenly revived. As has always been the case, terza rima versions have a certain Ulyssean character, because they try to imitate the unique basic form of Dante's Comedy, its unrepeatable DNA. In the past, terza rima translations always left a lot to be desired because of the enormous pressure put on the translator by the endless rhyme chain. This pressure is still very perceptible in recent terza rima translations, but on the other hand, it is only fair to say that some of the recent translators have learned a great deal from their predecessors' mistakes.

Among the recent terza rima American versions, the most popular is certainly Robert Pinsky's (1994), but Michael Palma's (2002) needs to be mentioned as well. In the Netherlands, the most recent terza rima translation was produced by the joint venture of Ike Cialona and Peter Verstegen (2000). Let us start with what Pinsky has done with Ulisse's plea:

'O brothers who have reached the west,' I began,

'Through a hundred thousand perils, surviving all:

So little is the vigil we see remain

Still for our senses, that you should not choose

To deny it the experience - behind the sun

Leading us onward - of the world which has

No people in it. Consider well your seed:

You were not born to live as a mere brute does,

But for the pursuit of knowledge and the good. ${ }^{22}$

As becomes clear from this little fragment, Pinsky is a rather moderate terza rima translator. In fact, he does not completely follow the rhyme scheme of the original, but chooses instead to adopt a more flexible definition of rhyme. His translation, in fact, is based 'on a fairly systematic rhyming norm that defines rhyme as the 
same consonant-sounds - however much vowels may differ - at the end of the words', ${ }^{29}$ creating imperfect rhyme-triads like 'began : remain : sun'. Aware of the many dangers and difficulties of a fully rhyming terza rima translation, Pinsky chose this kind of flexible strategy in order to diminish the deformations of English syntax and idiom:

The goal is to make enough of a formal demand to support the English sentence, but not so monstrous a demand as to buckle it, or to mangle the particularly delicate gestures English syntax and idiom make as they accomplish work another language might perform with inflected endings. ${ }^{30}$

At the same time, Pinsky honors terza rima as an essential element of Dante's poetry:

By devising terza rima as the body for a poem about the fates of souls and bodies, Dante added an expressive element as well as a kind of movement. His variations in tone and idiom - from direct to elaborately rhetorical, for example, or from high to low - have an emotional truth that moves in counterpoint with the current of interlocking rhymes. ${ }^{3 \mathrm{I}}$

In his own translation, Pinsky emphasizes above all the speed of Dante's unique meter, an aspect that in English verse translations was always so difficult to attain:

The prosodic embodiment Dante invented for his poem is characterized by tremendous forward movement, a movement that, in English, the prose translations have sometimes rendered more effectively than those in verse. ${ }^{32}$

In order to recuperate Dante's velocity in English verse, Pinsky has taken the liberty of using many enjambments, 'at times letting the sentence run over the rhymed ending more aggressively than in the original, and also crossing freely from tercet to tercet.' 33

One last surprising fact of Pinsky's translation is that the number of verses does not correspond to that of the original: in fact, many cantos are shorter than their Italian counterparts. In commenting upon the modernist terza rima translation by Laurence Binyon (1933, 1938, 1943), ${ }^{34}$ Ezra Pound had already mentioned the possibility that an English verse translation might very well be shorter than Dante's original text. ${ }^{35}$ Pinsky seems to have taken up this old suggestion, using it as one more instrument for regaining some of the formal energy of the original text that is usually lost in the process of translating. He explicitly asserts:

In order to represent Dante's succint, compressed quality along with the flow of terza rima, I have often found it necessary to write fewer lines in English than he uses in Italian. ${ }^{36}$ 
Partly because of these daring but controversial choices, Pinsky's version has encountered as much criticism as it has found enthusiastic readers. According to Theodore J. Cachey, for example, 'one might say that Pinsky's terza rima Inferno is post-modern to Binyon's modernist monument'. Cachey also states that the kind of translation presented by Pinsky is necessary, because through its creative approach it can

communicate the still-living legacy of the poem to a new generation of English language readers, as well as to those already familiar with the original who will find in this translation a different poem from the one they thought they knew. ${ }^{37}$

Compared with Robert Pinsky, the poet Michael Palma has made a less innovative rhyming translation through which certainly shine his great merits as a poet, but unfortunately also some of the shortcomings that were intrinsic to many previous terza rima versions:

'Through a hundred thousand dangers we have steered, my brothers,' I said, 'to reach these western gates.

Now has the brief vigil of our senses neared

its close, so let us not forswear our fates

but embrace experience, tracing the sun's route

to the uninhabited region that awaits.

Consider your origins. Living like a brute

is not the destiny of men like you,

but knowledge and virtue ever our pursuit. ${ }^{38}$

In spite of the inevitable semantic sacrifices any terza rima translator has to make, Palma states in his introduction that for him Dante's text is 'if not quite sacred, then certainly inerrant'. ${ }^{39}$ Palma's attempt to remain as faithful as possible to Dante has brought him 'to make poetry in the way that Dante does, which is, for the most part, through rhythm and sound, not through extravagant figures of speech'. ${ }^{\circ}$ More than a translation, Palma's translation has to be seen, according to its maker, as

a poet's response to the poetry of the Inferno, and an attempt to convey to readers of English, as far as it is in my power to do so, some sense of the integrity and the artistry of that extraordinary and inimitable work. ${ }^{4}$

Ike Cialona and Peter Verstegen express similar claims about the poetry of the Inferno in the preface to their recent Dutch terza rima translation. In order to 
obtain a poetical translation, the Comedy has to be considered 'first and foremost as a poem, a text in which the thoughts are carried by the music of metre and rhyme, rhythm, alliteration and assonance. ${ }^{2} 2$ Therefore, Cialona and Verstegen consider rhyme, prosody and metre to be the most important aspects; they fully admit and accept loss of semantic detail. ${ }^{43}$ In their rendering Ulisse's speech sounds as follows:

'O broeders,' zei ik, 'die reeds veel moest lijden,

Jullie zijn, het gevaar ten spijt, de west

Nabij, wil je er nu op voorbereiden

Dat wij in wat ons nog aan leven rest

Een wereld vinden waar geen mensen leven;

In 't spoor der zon zoeken wij dat gewest.

Denk aan je afkomst: 't is ons niet gegeven

Te leven als het redeloze beest;

Wij horen deugd en kennis na te streven.'44

This translation certainly sounds very smooth and colloquial, but we cannot overlook the typical shortcomings caused by the use of terza rima. In this fragment, for example, the translators had to add several words and constituents, but, more importantly, because of the stress on the rhyming words, the rhythm has become too monotonous.

\section{Back to Ulisse, his Companions, and Dante}

How does this story end? In the Comedy, as is well known, Ulisse's fearless point of view prevails. After his short but oh so powerful plea, his hesitant companions suddenly become even more eager than their leader to 'pursue virtue and knowledge'. They all change into Ulisse-clones, and the whole group engages in a 'folle volo', which five months later, through Divine intervention, tragically ends in shipwreck and death. Is this ultimately also the fate of the daring terza rima translator? At times, it is. However, among the recent intrepid translators, several have learned a great deal from their drowned predecessors. And sometimes, on a small scale, miracles do happen, for example when a poet of the caliber of Richard Wilbur puts his lifelong experience, all his mastery and patience in the effort of recreating one sublime canto in terza rima..$^{45}$

Should translators therefore always be humble and hesitant, like Dante himself in the Ulisse episode and in the rest of the Divine Comedy? In general, probably they should, and a modest translational strategy might very well lead to the best overall results. On the other hand, it should not be forgotten that Dante himself is double-faced in this respect. On a deeper level, in fact, Dante himself is a kind 
of Ulisse as well, not as a character of his own fiction, but as the writer of a poem which continuously transgresses the boundary between life and death. This Dante pretends to be God, judging his fellow men and describing paradise and ultimately God himself. ${ }^{46}$ The ideal translator of the 'poema sacro' should at least have some of this Dantean hubris as well. 



\section{The Translations of Dante's Comedy in America}

PAOLO CHERCHI

Dante's popularity in the Anglo-American world is so wide-reaching that it has become a topic of research in itself. Perhaps anyone who has just touched upon this topic is familiar with the work of Angelina La Piana, ${ }^{\mathrm{I}}$ William De Sua, ${ }^{2}$ and Gilbert F. Cunningham, ${ }^{3}$ the most extensive and exhaustive of them all. These works are indispensable and yet somewhat outdated since the most recent of them is now almost forty years old, and in these last four decades there has been a remarkable number of new translations and new experiments, and a great deal of theoretical work on translating has been done, too.

Cunningham's tables tell us that the translations of the Comedy in English (including those of just one cantica or a set of cantos) up to 1965 number 85 , of which 22 are American. Perhaps today the total number of translations into English has exceeded Ioo, considering that hardly a luster passes without producing one or two new translations of the Comedy. This number would be considerably higher if we were to count the translations of Dante's minor works as well. Unfortunately, what is lacking is a comprehensive study that covers these last decades, ${ }^{4}$ and we certainly do not intend to fill this lacuna. Space does not allow us to do so. Lack of specific competence on my part advises me not to attempt it. The occasion is not the appropriate one either, since I have been invited to give a rapid overview of the English translations in order to establish a reasonable basis of comparison for the Dutch translations that are being discussed at this conference.

I will give a succinct survey just of the American translations, beginning with the first one from 1843 (the first one done in the UK dates from I782) and ending with the ones of this last luster. However, I will dwell longer on the translations that appeared in the last half century, in part because, as I just mentioned, this is the period that scholars working on this subject have not covered. The reason for going that far back is that some of the earliest translations continue to be a model for today's translators. Moreover, such a long overview can be particularly useful for appreciating the quality and the level of experimentation attained by any new translation. Indeed, it should not be forgotten that in each case the base text, the Comedy, remains unchanged, while every translation makes it new. This consideration suggests that the best method to present innovations and differences in a comparative way is to work on some specific passages of the Comedy and see how different translators dealt with them over the course of time. In other words, from 
any of the translations examined - and I will select only those which seem to me the most significant ones - I will excerpt always, or almost always, fragments corresponding to the same passages in Dante. Furthermore, I will try to place every translator in his or her cultural context because translations, like any other forms of critical interpretation, have cultural roots.

As a preliminary note, I would like to recall that Dante's reception in America began in the Romantic period and has not paused since then. This remarkable success should not lead us into believing that Dante was at all times considered one of the greatest poets ever. Modern appreciation of Dante begins everywhere with the Romantics, and this also holds true for Italy, Dante's motherland. In sixteenth-century Italy, Dante was neglected to such an extent that only two editions of the Comedy were published, and that when a poet like Marino on a few occasions referred to the Comedy, he did so in a comic vein.

\section{A Dentist and the First 'Dantista'}

The first American translation was made by Thomas William Parsons, a dentist by profession, who spent long periods in Italy. Like any cultivated person in those days, he had a good knowledge of the classics and even wrote some poems in Latin. His translation of the first ten cantos of Inferno appeared in $1843^{5}$ and the complete translation of the Inferno in $1867 .{ }^{6}$ Two years earlier, in Florence, on the anniversary of Dante's birth, his translation was presented to a committee appointed to give prizes to works of this kind. Several years later, he published a translation of the first cantos of the Purgatorio. ${ }^{7}$ After trying to use terza rima, Parsons chose the solemn quatrain of the Gray and Dryden type, because, he thought, it was a meter that allowed him to include everything that Dante said in his dense terzinas. The quatrain was a heroic meter well suited for the sublime poetry of Dante, but it was also a popular meter, and thus appropriate for the mixture of sublime and popular that Parson saw in the Comedy. In fact, quatrains did not coincide well with the terzinas, and therefore Parsons often had to insert zeppe and additions, occasionally making some cuts as well. In general, his language is clear and efficacious, and it tends to be modern.

It so happened that Parsons lived for a time in Boston, where he became acquainted with Longfellow and Norton, the real founders of the great American 'dantismo'. They appreciated Parsons's work, although C.E. Norton advanced some serious criticism, which implied that there was a better way of translating Dante. For example, Norton found that

$[\ldots]$ e io sol uno m’apparecchiava a sostener la guerra sí del cammino e sí della pietate,

(Inf. 2, 3-5) 
I only rose and girt myself to fight

The struggle with compassion and my road

was inadequate. Norton also found that the meaning of 'io sol uno m'apparecchiava' was not rendered faithfully by Parsons. According to Norton a closer translation would sound something like 'I all alone was preparing myself'. Furthermore, he judged the inversion of 'pietate' and 'cammino' as awkward, and he found the following translation too modern:

me degno a ciò né io né altri 'l crede.

Per che, se del venire io m'abbandono, temo che la venuta non sia folle.

(Inf. 2, 33-35)

which Parsons rendered as:

Me worthy! no. I cherish no such a dream;

Should I resign me to thy charge, I fear

th'attempt would prove but madness in the extreme.

Henry Wadsworth Longfellow, the Bostonian poet, professor at Harvard, very learned and curious, can be considered the father of American 'dantismo', because his translation was read by generations of Dante's admirers, and it has influenced many translators, both in a positive and in a negative way. His translation of the entire poem, soberly annotated, appeared in $1867 .{ }^{8}$ It is a translation in blank verse, i.e. in terzinas without rhyme. This meter allows Longfellow to follow Dante line by line and to follow Dante's syntax as closely as possible. Longfellow's translation is characterized by its faithfulness, by its clarity, and by its restraint from additions and manipulations of the text; and this last fact is most remarkable considering that the translator was a poet, and poets tend to make the work they translate into their own. Longfellow's knowledge of Italian was impeccable, and he was very familiar with the culture of Dante's time. Perhaps this familiarity with Dante's world and language kept him from 'remaking' the poem. He translated the Comedy using the approach that in those days was used in translating classical authors. One perceives the influence of this approach in Longfellow's predilection for polysyllables, which give the text a classical aura and which, perhaps, are meant as a reaction to the popular vein Longfellow found in Parsons's translation.

Let us now examine a sample of Longfellow's text taken from Paradiso, which in general presents the greatest difficulties for a translator because of its frequent 
neologisms and Latinisms. The passage I have chosen is not particularly difficult for its syntax, but it is quite engaging for its lexicon, especially for the semantic nuances of some words:

$[\ldots]$ «Quanto fia lunga la festa

di paradiso, tanto il nostro amore

si raggerà dintorno cotal vesta.

La sua chiarezza séguita l'ardore;

l'ardor la visïone, e quella è tanta

quant' ha di grazia sovra suo valore.

Come la carne glorïosa e santa

fia rivestita, la nostra persona

piú grata fia per esser tutta quanta;

per che s'accrescerà ciò che ne dona

di gratüito lume il sommo bene,

lume ch'a lui veder ne condiziona;

onde la visïon crescer convene, crescer l'ardor che di quella s'accende, crescer lo raggio che da esso vene.

Ma sí come carbon che fiamma rende, e per vivo candor quella soverchia, sí che la sua parvenza si difende;

cosí questo folgór che già ne cerchia fia vinto in apparenza da la carne che tutto dí la terra ricoperchia;

né potrà tanta luce affaticarne ché li organi del corpo saran forti a tutto ciò che potrà dilettarne.»

(Par. 14, 37-60)

Longfellow's translation runs like this:

[...] As long as the festivity

Of Paradise shall be, so long our love

Shall radiate round about us such a vesture. 
Its brightness is proportioned to the ardour,

The ardour to the vision; and the vision

Equals what grace it has above its worth.

When, glorious and sanctified, our flesh

Is reassumed, then shall our persons be

More pleasing by their being all complete;

For will increase whate'er bestows on us

Of light gratuitous the Good Supreme,

Light which enables us to look on Him;

Therefore the vision must perforce increase,

Increase the ardour which from that is kindled,

Increase the radiance which from this proceeds.

But even as a coal that sends forth flame,

And by its vivid whiteness overpowers it

So that its own appearance it maintains,

Thus the effulgence that surrounds us now

Shall be o'erpowered in aspect by the flesh,

Which still to-day the earth doth cover up:

Nor can so great a splendour weary us,

For strong will be the organs of the body

The everything which hath the power to please us.

60

[Ill. 8, Paradiso I4]

Just to give some idea of the difficulties of Dante's language, we should mention that the word 'festa' (37) is used in a figurative way to say 'spiritual joy'; 'si raggerà' (39) is a neologism, because it turns an intransitive verb into a reflexive one, with the difficult meaning of 'it will dress itself of rays, of light'. Longfellow's translation, as we perceive immediately, runs smoothly and keeps the same rhythm and dynamic of the arguments as in the original.

'Festivity' (37) may not render well Dante's sense of 'festa' which means the 'joy of beatitude', which is perpetual and never changing, whereas 'festivity' implies a degree of temporality, of a break in the normality. 'Shall radiate round about us such a vesture' (39) misses the reflexive connotation meant by Dante. In the following verse 'séguita' (40), meaning 'is a consequence of', is rendered with 'is proportioned' (40), which replaces a dynamic notion of cause/effect with a notion of balance and harmony. 
Notice the successful repetition of 'vision' and the beautiful rendering of 'è tanta' (4I) with 'equals' (42), which falls within that isotopy of 'balance' just mentioned. Also beautiful is the translation of 'santa' (43) with 'sanctified' (43): 'saint' would have been weak and even wrong. Observe that Longfellow maintains the enjambment between 'santa' and 'fia vestita'. 'All complete' (45) renders 'tutta quanta' (45), although 'whole' would have conveyed in a better way the image of the original, but it would have required an alteration in the meter. Worth mentioning is the parallelism of 'crescer [...] crescer' (50-5I) that is rendered with 'increase [...] increase' (50-5I), and also the translation of 'effulgence' (55) for 'folgór' (55), which presents one of those polysyllables Longfellow liked. The translation of 'si difende' (54) is not very clear, but Longfellow understands it quite well and renders 'maintains' (54).

On the whole Longfellow's is an accurate and elegant translation, and therefore its great and lasting success does not come as a surprise. From the popular or 'cantabili' verses of Parsons, we pass to the aristocratic, dry, and powerful verses of Longfellow. His closeness to the Italian original, to its syntax and verse order made clear to English readers that Dante's sentences often do not coincide with the verses, as was the case with much of Romance poetry, but spill into the following verse, creating a sort of rhythmic prose. This observation was bound to suggest an experiment of a new translation directly into prose.

\section{The First American Prose Version}

Sticking close to a text such as the Comedy showed once again the intrinsic difficulties of translating poetry. Longfellow got as close as possible to Dante's text, but it was precisely that margin that remained unsurpassable which created frustration and caused a temptation to abandon verse translating, since it cannot catch all the musical and linguistic nuances, and instead use prose for the language of arrival. A translation in prose allows one to transpose in a different language - or in all languages for that matter - the thoughts and the images found in a poem and do it faithfully, even if this means losing all the other aspects that make poetry what it is. Thoughts and images can be translated easily and faithfully into other languages and in the most different linguistic families. For these reasons, when Charles Eliot Norton translated the Comedy, he decided to do it in prose. His was the first American prose translation, but in England it had been done before.

Charles Eliot Norton was from Boston and taught art history at Harvard, where he also taught the course on Dante which had been previously taught by Lowell, another important Dante admirer and scholar of the same Bostonian group. We have already seen that in the early years of his career he reviewed and made negative remarks on Parsons's translation, and this interest in Dante and Dante studies was to last as long as he lived, doing all he could to make Dante's work known. In his youth, he had translated the Vita nuova in a flowery prose 
and maintained the same flowery language in rendering the poetical parts. About thirty years later, in I89I-I892, he published his prose translation of the Comedy. ${ }^{9}$ This interval of three decades caused some changes in his way of thinking about translations. In presenting his work he wrote:

In this case the aim of the translator should be to render the substance fully, exactly, and with as close a correspondence to the tone and style of the original as is possible between prose and poetry $[\ldots]$

And he went on to say that the translator must find a word-by-word correspondence, although sometimes the words change meaning or have a semantic nuance that gets lost in passing from one language to another. Let us see a sample of Norton's translation using the same passage as for Longfellow:

As long as the festival of Paradise shall be, so long will our love radiate around us such a garment. Its brightness will follow our ardor, the ardor our vision, and that is great in proportion as it receives of grace above its own worth. When the flesh, glorious and sanctified, shall be clothed on us again, our persons will be more acceptable through being all complete; wherefore whatever of gratuitous light the Supreme Good gives us will be increased - light which enables us to see Him; so that our vision must needs increase, our ardor increase which by that is kindled, our radiance increase which comes from this. But even as a coal which gives forth flame, and by vivid glow surpasses it, so that its own aspect is defended, thus this effulgence, which already encircles us, will be vanquished in appearance by the flesh which all this while the earth covers; nor will so great a light have power to fatigue us, for the organs of the body will be strong for everything which can delight us.

It is easy to see that Norton was looking at Longfellow's translation while working on his own. The contacts are so many and obvious that it would be a waste of time to point them out. It would suffice to mention that 'effulgence' (55). Some differences are more significant: Longfellow's 'whiteness' (53) has been substituted by 'glow'; 'Good Supreme' (47) becomes a more prosaic 'Supreme Good'. Both the similarities and the differences confirm what we said about the 'prose-quality' of Longfellow's translation, which ultimately depends on the esthetic principle of 'literalism' applied to translations.

\section{New Experiments}

After Norton's, there was a stream of new translations that looked for other ways through the influence that these two earliest translations exercised for many years. There were, among others, the translation by Marvin Richardson Vincent in $1904,{ }^{\text {IO }}$ that by Henri Johnson in 1915 - which is perhaps the closest one to 
Longfellow, ${ }^{\text {II }}$ that by Courtney Langdon, published between 1918 and I92I, interesting for its distancing from Longfellow's. ${ }^{\text {I2 }}$

In 1933 the translation of Jefferson Butler Fletcher appeared, which is memorable for its use of the irregular terzina. ${ }^{13}$ In I934-1940, there was one by Louis How, noticeable for its lack of faithfulness to the original. ${ }^{14}$ About a decade later, there was the translation by Thomas Bergin, ${ }^{\mathrm{IS}}$ and in 1948 that by the architect Lawrence Grant White in 'blank verse', free from archaisms and elevated expressions. ${ }^{16}$ In addition, also in 1948 , there appeared the translation by Patrick Cummins. ${ }^{17}$

All these translations are meaningful because, even though they are not memorable for their beauty nor for their success (some of them, however, are still popular today), they represent a notion of translating which prevailed for many decades, roughly between the end of the nineteenth century and the middle of the twentieth. This notion was based on the principle of 'literalism' that was used both by Longfellow and by Norton, a principle that stems from the Romantic and especially from the Victorian aesthetic. However, the above-mentioned translations also represent a change through which that same notion of 'literalism' went.

The factor that brought on the crisis was a 'formalistic' aesthetic that considered content and form as an indivisible unit, an aesthetic by which in the artistic expression the form is its content and the content is its form. The key supporters, indeed the real founders, of this new aesthetic were Ezra Pound and T.S. Eliot, who also happened to be some of the greatest twentieth-century admirers of Dante. They taught their contemporaries how to appreciate Dante's art, its linguistic 'realism' that makes visible what it tries to represent, including its allegorical descriptions. Dante's language is so realistic to the point of being symbolic. Dante's language contains the reality. An earlier aesthetic took reality to be the 'content' of art, whereas formalists see that artistic language is not artistic unless it conveys through 'enargeia' or 'evidentia' the world that it creates. This is why a translator must consider the formal aspect as an essential tool of his work, and he must try to capture that consubstantiality of form and content, which is the trademark of real art.

The passage from the Romantic-Victorian to the formalistic way of thinking about translation was a slow one. However, it is already evident in some of the abovementioned translations. A case in point is that of Fletcher, who used irregular terzinas, i.e. terzinas that respect Dante's terzina only in part. Here is an example:

La gloria di colui che tutto move per l'universo penetra, e risplende in una parte piú e meno altrove.

Nel ciel che piú de la sua luce prende

(Par. I, I-4) 
The Glory of Him who moveth all He made

Shines through the universe with piercing splendour

In one part more, and elsewhere less displayed.

Up in that heaven that most receives His light

This terzina rhymes, although not perfectly, lines one and three, but line two, which in Dante rhymes with line four, remains unmatched. This is an attempt to free the syntax from the constrictions of the rhyme, yet the rhyme is not completely abandoned, and its reduced presence still reminds the reader that poetic language is also characterized by musicality and challenging limitations, which strengthen the intensity of artistic expression. This formalistic concern pushed translators to experiment again with the terzina and with a mixture of archaism, learned words, and dialectal expression, as we can see in Cummins's translation.

\section{John Ciardi: from Translation to Transposition}

These repeated experiments, which are in part breaking the ties with the previous kind of 'content-oriented' translations and in part continuing it, prepared the path to Ciardi's courageous rendering, which must be considered as a real achievement in the history of American translations of the Comedy. John Ciardi, a professor of English and a poet in the Eliot line, published the translation of Inferno in 1954, that of Purgatorio in 1961, and that of Paradiso in $1970 .{ }^{18}$

In his preface, Ciardi outlines the principles that have guided his work. He speaks of it not as a 'translation' but as a 'transposition', a term that indicates a departure from a word-by-word rendering, which is not possible to carry out with poetry because poetry

is not made of words but of word-complexes, elaborate structures involving, among other things, denotations, connotations, rhythms, puns, juxtapositions, and echoes of the tradition in which the poet is writing. It is difficult in prose and impossible in poetry to juggle such a complex intact across the barrier of language. ${ }^{\text {I9 }}$

'Transposition' does not intend to transpose the thought of a work as prose translations do, but it must convey it together with a sense of the original's language. It must not use a word-by-word correspondence, but should find a language that is really a 'living language'. Transposition is essentially a recreation of a living language in another living language. In translating the Comedy, a translator must use

a language as close as possible to Dante's, which is in essence a sparse, direct, and idiomatic language, distinguishable from prose only in that it transcends every known 
notion of prose. I do not imply that Dante's is the language of common speech. It is a much better thing than that: it is what common speech would be if it were made perfect.

One of the main sources of the tone of Dante's speech is his revolt from the Sicilian School of Elegance. Nothing would be more misleading than to say that Dante's language is simple. Overwhelmingly, however, it seeks to avoid elegance simply for the sake of elegance. And overwhelmingly it is a spoken tongue.

I have labored therefore for something like idiomatic English in the present rendering. ${ }^{20}$

Let us see how these criteria are applied by Ciardi himself. ${ }^{21}$ Let us take a wellknown passage from Purgatorio 26:

E io a lui: «Li dolci detti vostri

che, quanto durerà l'uso moderno,

faranno cari ancora i loro incostri».

«O frate», disse, «questi ch'io ti cerno

col dito,» e additò un spirto innanzi,

«fu miglior fabbro di parlar materno.

Versi d'amore e prose di romanzi soverchiò tutti; e lascia dir li stolti che quel di Lemosí credon ch'avanzi.

A voce piú ch'al ver drizzan li volti, e cosí ferman sua oppinïone prima ch'arte o ragion per lor s'ascolti.

Cosí fer molti antichi di Guittone, di grido in grido pur lui dando pregio, fin che l'ha vinto il ver con piú persone.

(Purg. 26, II2-I26) [Ill. 5, Purgatorio 26]

Here is Ciardi's transposition of this passage:

And I to him: 'Your songs so sweet and clear which, for as long as modern usage lives, shall make the very ink that writes them dear;' 
'Brother,' he said, 'that one who moves along ahead there,' (and he pointed) 'was in life a greater craftsman of the mother tongue.

$\mathrm{He}$, in his love songs and his tales in prose, was without peer - and if fools claim Limoges produced a better, there are always those

who measure worth by popular acclaim, ignoring principles of art and reason to base their judgments on the author's name.

So, once, our fathers sent Guittone's praise, and his alone, bounding from cry to cry, though truth prevails with most men nowadays.

This translation is quite free, a real 'transposition', with changes of words and of images. Yet, it has its strength and is highly readable. The secret of this success rests on its idiomatic liveliness. Take, for example, the addition of 'clear' (II2), which is not due to rhyme reasons as much as to respect for the notion of 'visual images' promoted by Pound and Eliot. Yet, it acquires new energy and connotations when combined with 'songs' (II2) rather than with 'detti' (II2) or 'words': sweet songs are 'sentimental', but if they are also 'clear', they contain an intellectual message with philosophical and even political implications.

'Lives' (II3) is plainer than 'endures' or 'lasts' but is also more common and therefore more spontaneous. 'Prose di romanzi' (II8) becomes 'tales in prose' (II8), presenting an interesting inversion by which the genre 'romanzo' (roughly corresponding to contemporary 'soap novels') is reduced to its core matter, to its narrative potentiality, and 'in prose', while retaining part of the original, in fact emphasizes the plain force of that 'telling in tales'. 'Quel di Lemosí' (I2O) becomes 'a product' of Limoges (II9-I2O), substituting Dante's very medieval notion of 'origins' with one having a ring of modernity and of 'industrial' mentality. The same can be said for 'by popular acclaim' (I2I) which is modern and 'democratic'; also modern and specifically American is 'fathers' (I24) for 'antichi' (I24) since it is clearly related to the notion of the 'founding fathers'.

To have a better appreciation of how distant Ciardi's transposition is from the literalist work, let us compare it to two earlier translations, just limiting ourselves to the first two terzinas. Here is Jefferson Butler Fletcher's rendering:

And I: 'The sweet songs thou wast wont to sing,

Which long as modern usage shall endure

Will make their very ink a precious thing.' 
O brother, he whom I point out among

These spirits,' answered he, and pointed, 'was

the better craftsman in his mother tongue.'

(Purg. 26, II2-II7)

It is enough to see 'wast wont' (II2) to understand that we are really far away from Ciardi. However, it must be pointed out that Ciardi adopts the 'irregular terzina' used by Fletcher because he finds it useful in making the syntax more flexible and to create metric units, which are closer to spoken language.

Let us now see Louis How's translation:

And I to him: 'Your ditties sweet - till sink

Our modern usages into a myth -

Will render precious still their very ink.'

'O brother,' said he, 'him I locate with

my finger,' showing a spirit in advance,

'Was, in his mother tongue, a better smith.'

II7

(Purg. 26, II2-II7)

Here we are even farther away from Ciardi, because of both the terza rima and the archaic language. Nonetheless, in How's translation there is a freedom of intervention that overcomes Fletcher's cautiousness and seems to forerun Ciardi's.

These samples give an idea of the gradual change from daring experimental translations (yet still indulging in archaisms and lofty language) towards a 'demotic' transposition - to use De Sua's qualification - that is, towards a way of rendering Dante contemporary and democratic as he was in his day.

\section{The Modern Translations}

\section{Charles Singleton}

Ciardi opens the period of 'modern' translations of the Comedy. It is fair to say that Ciardi gave new impetus to Dante translations, by showing how his lucid and yet dense language, the complex nature of his work, which combines ballads and meditations, intellectual projects and epic aspirations, is capable of being constantly new and therefore always needing new translations.

The last few decades have been very important for Dante studies in America. These have benefited from the general revival of medieval studies, a revival with strong emphasis on allegorical approaches and on a European dimension, so that Dante has become a canonical reading for all medieval students. Charles Singleton, who imposed a new way of reading Dante, has also promoted a 
renovation of the critical approach to translating Dante. Singleton was a professor, and many new wave Dante translators have been professors. Singleton himself translated the Comedy in prose, ${ }^{22}$ which makes perfect sense with his view of Dante as a strong thinker, as thought comes through better in a prose translation. However, this is not accurate: Singleton wanted above all to write a commentary to Dante's Comedy, and a prose translation was perfectly suitable for this plan, especially for a commentary which pays no attention whatsoever to 'poetic' form.

This infusion of philology has acutely revived the problem of translating Dante. It is not the general problem of translating poetry, but a special type of poetry, which in its language presents a high dose of symbolic and technical information which cannot be ignored without losing a great deal at both the formal and the content level. Thus, it is impossible to think of form and content as two separate elements. A commentary can hardly make up for these losses; in fact, it can be the indirect proof of a failure of what the translation has been unable to retain of the original. A philosophical term must be translated as closely and faithfully as possible, rather than be explained in a footnote or rendered with a paraphrase, because that precision is an intrinsic part of Dante's language. Such awareness prompts different solutions. One of the possible solutions is to relapse into literalism. Another solution would be to renounce a poetical rendering altogether and to use a prose translation instead. Another is a solution of compromise that is as faithful as possible to the original, but that needs the support of a commentary. The boldest solution tries to render the poetic and narrative 'dynamic' of the poem without being worn down by philological and formal details. A new generation of translators was to experiment with the renewed awareness that the Comedy is also a 'philosophical' poem.

\section{Mark Musa}

The first of this new generation of translators is Mark Musa, a direct student of Singleton's, translator of the Vita Nuova and the author of several studies on Dante. His translation of the Comedy appeared in the period $197 \mathrm{I}-1984^{23}$ and has enjoyed remarkable success, in part because of the prestige of the Penguin series that published it, ${ }^{24}$ in part because it satisfies both the scholastic and the lay needs thanks to a sober yet enlightening commentary. In his preface, Musa states that his aim was to translate without letting his reader know that he is translating, to be faithful without appearing to be. Musa wanted to keep a middle road between those who translate the Comedy with a magniloquent and flowery language, and those who are less inclined to look for effects and prefer a language close to a zero level of poetic embellishment, and whose highest achievement is found in a prose translation. Musa understands that the choice between these two kinds of rendering is a matter of taste and that they are both partly wrong and partly right. They both find their justification in Dante's text: Dante is magniloquent, but not in a 
systematic way, and Dante is also prosaic, but not in a systematic way either. Musa prefers to follow Dante in his stylistic changes, and he does not consider himself to be betraying Dante when using a simple or disadorned language, since Dante uses this kind of language more frequently than is normally thought, nor does he consider to be betraying him when he elevates the language of his translation to the peaks of sublimity.

Musa just wants to be faithful to his author. However, he must depart on one point, namely on the structure of the terza rima. Musa gives up the rhyme because, if it is a difficult obstacle for a poet, it is an impossible one for a translator. Musa adopts a system of terzinas made with iambic pentameters, thus going back to a Miltonian type of verse, which English poetry has often used in lengthy works of narrative nature. Let us see two samples of these two different styles, one 'simple' and the other magniloquent. Take, for instance, the first two terzinas of the Comedy:

Nel mezzo del cammin di nostra vita mi ritrovai per una selva oscura, ché la diritta via era smarrita.

Ahi quanto a dir qual era è cosa dura esta selva selvaggia e aspra e forte che nel pensier rinova la paura!

(Inf. I, I-6)

Musa translates this as follows:

Midway along the journey of our life I woke to find myself in a dark wood, for I had wandered off from the straight path.

How hard it is to tell what it was like, this wood of wilderness, savage and stubborn (the thought of it brings back all my old fears),

a bitter place! [...]

[Ill. I, Inferno I]

Musa respects the ordo naturalis of the model, and even when he abandons it in line four, Musa still keeps it because in English the inversion would sound too artificial. The vocabulary is quite faithful to the source text. Musa loses the alliteration 'selva selvaggia' and the epiphrasis 'e aspra e forte', which is turned into a 
parenthetic syntagm with the value of apposition. Overall, the verses run smoothly, thanks in part to the lack of rhyme. The second passage is taken from the highly dramatic canto of Geryon:

e disse: «Gerïon, moviti omai:

le rote larghe, e lo scender sia poco;

pensa la nova soma che tu hai.»

Come la navicella esce di loco

in dietro in dietro, sí quindi si tolse;

e poi ch'al tutto si sentí a gioco,

102

là 'v' era 'l petto, la coda rivolse,

e quella tesa, come anguilla, mosse,

e con le branche l'aere a sé raccolse.

IO5

Maggior paura non credo che fosse quando Fetonte abbandonò li freni, per che 'l ciel, come pare ancor, si cosse;

I08

(Inf. 17, 97-108)

And Musa translates:

and then he cried: 'Now Geryon, start moving, descend with gentle motion, circling wide: remember you are carrying living weight.'

Just as a boat slips back away from shore, back slowly, more and more, he left that pier; and when he felt himself all clear in space,

to where his breast had been he swung his tail and stretched it undulating like an eel, as with his paws he gathered in the air.

IO5

I doubt if Phaëthon feared more - that time he dropped the sun-reins of his father's chariot and burned the streak of sky we see today IO8

The translation is as close as possible. One senses a lack of that sublimity that Dante's verses have - from the tension of horror to the mixture of natural and 
mythological comparisons, to the language that conveys that horror. Here Musa remains close to his ideal of medietas, with a tone that is closer to prose than to a simple language that, however, can convey sublimity as well as straight narrative. For example: 'Start moving' (97) is colloquial compared with the epic 'moviti omai' (97); 'come pare ancor' (IO8) is weakened and loses its mythic pertinence in 'sky we see today' (IO8); 'gentle motion' (98) is beautiful but weak; 'undulating' (IO4) is also beautiful but too literary and out of tune with the general medietas. On the whole, Musa's translation is functional, and this is an asset; but it does not always keep its promise to follow Dante's use of different styles: more often than not, the 'simple' style prevails. In Musa's case, the philology of his teacher had a restraining effect, and the results are not bad at all.

\section{Allen Mandelbaum}

Another important translation of this period is Allen Mandelbaum's. ${ }^{25}$ Mandelbaum, poet and professor of English literature, uses a terzina with 'blank verses', that is a terzina without rhyme and with Miltonian pentameters. It is a choice that allows Mandelbaum to render a Dante that he sees as a 'drummer', that is a poet with an emphatic language, with a style always on a high tone. Let us see the first two terzina of the Inferno:

When I had journeyed half of our life's way,

I found myself within a shadowed forest,

for I had lost the path that does not stray.

Ah, it is hard to speak of what it was, that savage forest, dense and difficult, which even in recall renews my fear

(Inf. I, I-6)

It is surprising to find in the opening line a temporal adverb and the first person pronoun representing the agens of the voyage. Clearly, Mandelbaum wanted to put in the foreground the 'drummer' Dante; but by doing so, he leaves in the background that everyman that Dante presents precisely in the first line ('nostra vita') and that is a fundamental part of the Comedy's allegorical plan. 'Dritta' rendered with 'does not stray' is a lofty literary periphrasis; so is 'dense and difficult' for 'selvaggia'.

For another sample, we can take the passage from Geryon's flight already seen in Musa's translation:

and said: 'Now, Geryon, move on; take care

to keep your circles wide, your landing slow; 
Just like a boat that, starting from its moorings, moves backward, backward, so that beast took off; and when he felt himself completely clear,

he turned his tail to where his chest had been and, having stretched it, moved it like an eel, and with his paws he gathered in the air.

I do not think that there was greater fear in Phaethon when he let his reins go freefor which the sky, as one still sees, was scorched Io8 (Inf. 17, 97-I08)

In this case, the constant 'emphatic' and high-level rhetoric component of Mandelbaum's translation gives its best. If we compare it to Musa's, we note a much higher lexical and syntactic register.

\section{Robert Pinsky}

A translation that attracted the attention of a wide audience is the work of Robert Pinsky. His translation of Inferno appeared in $1994 .{ }^{26}$ Pinsky is a poet, a 'laureate poet', and he wants to be a faithful poet-translator of Dante. In order to achieve this goal, he adapts the Italian poem, re-writing it to some extent and making it his own. He considers the main trait of Dante's poetry its 'tremendous forward movement', a movement that translations in prose sometimes have been able to capture better than those in verse. Therefore, Pinsky not only highlights this particular quality of Dante's text, but he accentuates it, either neglecting verses or using enjambments with unusual frequency, or adding words and ideas of his own. The result is that in many cantos the text of the translation is shorter than the original, sometimes by a considerable measure. For example, in the first canto there are only Io9 lines versus the $\mathrm{I} 37$ of the original. Another innovation concerns the use of 'dummy' terzinas, which resemble closely those used by Fletcher namely two verses rhyming and one left free - but they are not identical because Pinsky often substitutes the perfect rhymes with assonances, a substitution which is inspired by Yeats's poetry. Let us briefly consider the same passages seen for Musa's and Mandelbaum's translations. First, the opening terzinas of the poem:

Midway on our life's journey, I found myself

In dark woods, the right road lost. To tell

About those woods is hard - so tangled and rough 
And savage that thinking of it now, I feel

The older fear stirring: death is hardly more bitter.

And yet, to treat the good I found there as well

I'll tell what I saw $[\ldots]$

In this fragment, Pinsky translates three of Dante's terzinas into two of his own. The entire verse 'ché la diritta via era smarrita' (3) becomes simply 'the right road lost' (2). Notice also the frequent use of the enjambment - practically five instances in six verses - which confers 'speed' to the narrative. Let us also look at the episode of Geryon:

'Geryon, move ahead - but carefully:

Keep your arcs wide; go slowly when descending;

Be mindful of this new burden that you bear.'

As a boat moves back and back, to leave its landing,

So slowly did Geryon withdraw from shore.

Then when he felt himself quite free, he turned

And brought his tail to where his foreparts were,

And stretching it out he moved it so it churned

The way a swimming eel does; and his paws

Gathered the air toward him. When Phäeton spurned

The reins, so that the sky as one still sees

Was scorched, I doubt that there was greater fear [...]

In this case, the number of verses does correspond to that of the original, although the correspondence disappears if we consider the entire canto. Notice the assonances and the tendency to end a sentence in the middle of a verse, which reinforces the effect of the enjambment and bridges the gap between poetry and prose rendition. As becomes already clear from these small fragments, Pinsky's translation of the Comedy is by far the one least faithful to the original, but it is not the least interesting of them all. It is definitely the boldest of the experimental versions, and it would be quite acceptable if we did not perceive at times almost a parodic tendency, that is a tendency to hypercharacterize some of Dante's most prominent stylistic features, his narrative speed and brevitas. Dante is unrivaled in the use of brevitas, and trying to beat him in this respect runs the risk of impoverishing him greatly. However, it is precisely this potential fault that makes Pinsky's translation 
worthwhile, because it reveals a feature of Dante's poetry that is often overlooked. One cannot stop wondering at the richness of the Comedy if after so many translations it is still possible to have one that is so dramatically new.

\section{Robert M. Durling}

The last American translation I will consider in this context was made by Robert M. Durling and comes with a ponderous commentary by Ronald L. Martinez. ${ }^{27}$ It is a prose translation, but it is printed in such a way that it becomes possible to see the original scansion in terzinas on the facing page. To give a sample we read the translation of the two opening terzinas:

I) In the middle of the journey of our life, I came to myself in a dark wood, for the straight way was lost.

4) Ah, how hard a thing it is to say what that wood was, so savage and harsh and strong that the thought of it renews my fear!

Durling's is a straight translation with at least one surprise: 'I came to myself' is quite different from 'I found myself', which we have seen many times. The explanation for this new rendering is given in the commentary:

In our view, the prefix $r i$-, rather than denoting repetition here, serves to intensify the inward nature of the event: Dante is describing a moral awakening. ${ }^{28}$

This translation is an example of how scholarship pushes for precision and interpretation and how hesitant it makes a translator to use verse rendering. Singleton's philological approach ended up by giving more emphasis to the commentary than to the translation: the latter becomes a basis, a complement, or integration to the first. However, Durling's and Martinez's excellent commentary shows a hermeneutical attention to the text that was not present in Singleton's commentary and translation: it is a sign that professors are trying to understand the Muses as well as the philosophers. In view of this trend of professors translating the Comedy in prose, it is even more remarkable that the Hollanders' translation, which is the most recent to appear, is the fruit of wedding Philology with Poetry. The translators themselves will tell us how this wedding was arranged and what the results were. 



\section{Translating Dante into English Again and Again ${ }^{\mathrm{I}}$}

ROBERT HOLLANDER

The title of this paper reflects not only my wife's and my practice as we work through the Comedy, ${ }^{2}$ draft after draft, but that of British and American translators since the beginning of the nineteenth century. It is worth taking a moment to remind ourselves how much Dante in English has been and still remains available. John Ahern, in a useful survey of Translations in English in The Dante Encyclopedia, ${ }^{3}$ calculates a total of nearly Ioo English translations, in a total of some 200 volumes, since many have translated only a single cantica.

\section{A Crowded Field}

One should begin by mentioning the partial translations by Rogers and by Boyd in the late eighteenth century. ${ }^{4}$ However, the first translation that succeeded in finding a wide and significant audience (e.g. Blake, Keats, Melville) was that of Henry Cary (I805-I806, second, revised version in I815).5 In any case, in the past two centuries we find new translations of Dante into English appearing at the rate of one every two years. Talk about entering a crowded field... Further, since Ahern was writing, three years ago, two more Infernos have appeared, ours and the terza rima version by Michael Palma. ${ }^{6}$ Still further, a former student of mine, Anthony Esolen, is just now publishing his translation of Inferno - and there is word of at least one other shortly to appear. ${ }^{7}$

A brief survey of the better-known English versions of Dante's poem is perhaps worth having. Among the dozens of English Dantes that one may find still in print, there is a wide selection for a reader (or a teacher) to choose among. These are as follows, first those in prose, then those in verse:

\section{Prose:}

John Carlyle, Philip Wicksteed, Thomas Okey (I899-I90I)

John Sinclair (1939, 1946)

Charles Singleton (1970, 1973, 1975)

Robert Durling (1996 [Inferno], 2003 [Purgatorio])

\section{Verse:}

Henry Francis Cary (I805-I806)

Henry Wadsworth Longfellow (I867) 
Laurence Binyon (1933, 1938, 1943 [terza rima])

Dorothy Sayers, Barbara Reynolds (1949, I955, 1962 [terza rima])

John Ciardi (1954, 196I, 1970)

Geoffrey Bickersteth (1955 [terza rima])

Thomas Goddard Bergin (1969 [1948, 1953, 1954])

Mark Musa (1971, I98I, I984)

Allen Mandelbaum (1980, 1982, 1984)

C.H. Sisson (1980)

Nicholas Kilmer (1985 [Inferno])

Tom Phillips (1985 [Inferno only])

James Finn Cotter (1987)

James Torrens (1993 [Paradiso only])

Steve Ellis (1994 [Inferno only])

Robert Pinsky (1994 [Inferno only; slant rhyme)

Peter Dale (1996 [terza rima])

Elio Zappulla (1998 [Inferno])

W.S. Merwin (2000 [Purgatorio only])

Robert and Jean Hollander (2000, 2003 [Inferno, Purgatorio])

Michael Palma (2002 [Inferno, terza rima])

Anthony Esolen (2002 [Inferno] $)^{8}$

In short, there are approximately two dozen English Dantes that one can fairly easily obtain, even if some may be available only from suppliers of second-hand books.

\section{About Our Own Translation}

In our translation, we hoped to accomplish two things, to make our English version of the poem as clear as Dante allows his translator to be and to make it sayable as poetry - exactly what a prose translation may only occasionally try to accomplish. We have tried to stay as close to Dante's lexicon and style as possible, knowing that success in doing so is virtually unobtainable, but keeping that as our aim. The trade-offs between a 'literal' translation and an English poem that its reader can actually speak aloud make for a continuous and difficult negotiation, one, we both believe, that is better undertaken by two heads rather than one. Now that we have done it, we are surprised that we are the only ones to have collaborated on a translation of the Comedy. Either one of us doing this task alone would have produced a very different result, and not, I think, a better one. And while my main responsibility was scholarly and Jean's, poetic, there was a great deal of crossing over into the other's territory from early on.

In speaking with a group of scholars about translation, one realizes that questions of fidelity to the actual text, once one has selected the particular edition of the poem to be used (for us inevitably the Petrocchi text of 1966-1967 $)$ ), are of 
paramount interest. How does one reconcile the desire to be 'faithful' with the desire to make one's translation behave like a poem? The answer is simple: only with constant and considerable difficulty. Our translation is not a 'trot', and we may have taken a few more liberties than I am now pleased with. On balance, however, I think we have managed to stay closer to that intangible poetic being called 'Dante' than have most who have produced poetic translations.

\section{Against Rhyme}

And that is where we part company with those whose first priority seems to be the text of the translation itself. Let me address the issue as follows: Historically, the translator of the Commedia has had five options: (I) prose, (2) free verse, (3) blank verse, (4) 'false tercets' (the choice of John Ciardi), (5) terza rima. I confess I am astounded at how many have chosen this last option; fully five of the translations in that list of 26 we studied a moment ago are in rhyming tercets. In no case, I believe, has the result justified the risk. Rhymers eventually (I) stumble into awkward enjambments in order to pause on a rhyme word, or (2) create a childish tone (the Burma-Shave effect) because they, sooner or later, are forced to employ facile English rhymes that do disservice to Dante, or (3) add words or phrases that are not even vaguely related to what the poet actually wrote. Any of these probably unavoidable problems should be, in my opinion, reason enough to avoid rhyming.

Further, rhyming poetry is by and large not a part of our sense of 'serious poetry' in our time, while it remains a continuing presence in comic verse. Thus, for instance, while I would never attempt to translate Racine's Phèdre into rhyming Alexandrines, I would not try to translate a Molière comedy into anything else but rhyming couplets. I should add that the genial Richard Wilbur, who has brought Molière into English so very well, comes the closest, in the one canto of Dante he has published, to showing that one might actually rhyme him into English convincingly, but I nevertheless have a residual feeling that I was reading a translation of Molière's translation of the Commedia. ${ }^{\text {IO }}$

Let me offer a single example of what is wrong with the use of rhyme in translation. Sooner or later, one will commit an infelicity of the following kind. The text is Inferno 5, I06-8. Francesca is finishing her first speech, detailing her subservience to the god of Love:

'Amor condusse noi ad una morte.

Caina attende chi a vita ci spense.'

Queste parole da lor ci fuor porte.

['Love brought us to one death.

Caina waits for him who quenched our lives.'

These words were borne from them to us.] 
And here is a translation into rhyming tercets. It does not matter whose it is, the point being that, sooner or later, this sort of foolishness will afflict any rhymester.

'Love led us to a single death. The grim

Caïna waits to claim our murderer.'

These words were borne across to us from them.

It is probably worth pointing out that the forced and perhaps unintentionally amusing rhymes for 'murderer' are 'spirits were' and 'made me stir'. But what about that 'grim' in the first of the tercet's three verses? There is no 'grim' in Dante. The adjective, unloved and unwanted, is grafted onto the narrative for the sake, and only for the sake, of a banal English rhyme. The result is a weak passage and a misrepresentation of the source text. Translation of this kind destroys the very thing it seeks to replicate, the sound and feel of the original. This is perhaps all the experience I might require to reaffirm the belief that I would never want to use a rhyming translation, one that necessarily relied on such shaky principles.

I should add that, many years ago, I taught sections in a course that had adopted a rhyming translation of Dante as its text and, as a result, spent a huge amount of class time 'detranslating' the poem for students who had been reading something that only fitfully resembled the text of Dante's poem. I should add that I am perfectly aware that Dante himself is often forced by rhyme to some difficult and ungainly maneuvers. A translator as gifted poetically as Dante himself might well be able to escape from the jaws of necessity as gracefully as he. When you find him or her, please let us know.

If avoiding the exigencies of rhyme in order to protect the original is such a pressing concern, why not use a prose translation? Indeed, almost all of my forty years of teaching Dante in translation have been involved with the Sinclair or (much the same thing) the Singleton version. Why, then, attempt a verse translation? Over the years, an occasional student or colleague has asked me if I did not want to translate the Comedy. My answer was always to laugh. I would go on to add that I was not yet totally mad. Now I suppose that I am. I remember a conversation with Robert Pinsky that took place just as he was finishing his Inferno, in which I wondered at what he had done and volunteered that I would never have been so bold - and did not plan to be.

Our translation happened casually, the result of my wife's looking at some work I was doing in Florence, preparing the Sinclair version as the English text for the Princeton Dante Project (http://www.princeton.edu/ - dante), cleaning up the outdated diction (e.g. his use of 'thee' and 'thou'). My wife was harsh, urging the case against prose translations of poetic works for students, who necessarily lose any feel for the poetic fact of the original. Jean took Inferno $\mathrm{I}$, disappeared for a couple of days, and reappeared with what turned out to be the beginning of an intense collaboration. 
How do we judge the result? More importantly, how do you judge the result? The crucial question is this. If we can safely assume (I very much hope we can) that what we have accomplished sounds better than prose, can we also believe that we have dislodged Dante's sense little enough to justify the effort? It all comes down to no more and no less than that. It seems fair to conclude with a test case.

Here is the lovely simile, a mixture of Virgilian pastoral and everyday Tuscan agricultural elements that opens Inferno 24, first in John Sinclair's prose, and then in our free verse. The situation is this: Virgil has been irritated by the mocking of his intelligence by the shade of a Jovial Friar from Bologna, since he had been tricked by a devil and almost gotten Dante killed in an ambush:

In quella parte del giovanetto anno che 'l sole i crin sotto l'Acquario tempra e già le notti al mezzo dí sen vanno,

quando la brina in su la terra assempra

l'imagine di sua sorella bianca, ma poco dura a la sua penna tempra,

lo villanello a cui la roba manca, si leva, e guarda, e vede la campagna biancheggiar tutta; ond' ei si batte l'anca,

ritorna in casa, e qua e là si lagna, come 'l tapin che non sa che si faccia; poi riede, e la speranza ringavagna,

veggendo 'l mondo aver cangiata faccia in poco d'ora, e prende suo vincastro e fuor le pecorelle a pascer caccia.

Cosí mi fece sbigottir lo mastro quand' io li vidi sí turbar la fronte, e cosí tosto al mal giunse lo 'mpiastro;

(Inf. 24, I-I8)

\section{In Sinclair's prose:}

In that part of the youthful year when the sun refreshes his locks under Aquarius and already the long nights are moving away to the south, when the rime copies on the 
ground the likeness of her white sister but her pen does not long keep its point, the peasant who is short of fodder rises and looks out and sees the fields all white, at which he smites his thigh, turns back into the house and goes here and there complaining like a poor wretch that knows not what is to be done, then comes back and gathers hope again when he sees how in a little time the world has changed its face, and grasps his staff and drives forth his sheep to pasture; thus the Master made me lose heart when I saw his brow so clouded and thus quickly came the plaster to the hurt.

And here is our free verse version of the passage:

In that season of the youthful year when the sun cools his locks beneath Aquarius and the dark already nears but half the day,

and when the hoarfrost copies out upon the fields the very image of her snowy sister although her pen-point is not sharp for long -

the peasant, short of fodder, rises, looks out, and sees the countryside turned white, at which he slaps his thigh,

goes back indoors, grumbling here and there like a wretch who knows not what to do, then goes outside again and is restored to hope,

and, seeing that the world has changed its face in that brief time, and now picks up his crook and drives his sheep to pasture.

Thus the master caused me to lose heart when I saw how troubled was his brow and just as quickly came the poultice to the wound, 


\title{
'Getting Just a Small Part of It Right'
}

\author{
JEAN HOLLANDER
}

As a poet, I found translating Dante's Commedia both easier and much harder than working on my own poems. How comforting not to have to wait for the Muses to strike with an idea, an image, or a phrase, but to have the subject matter with all its complexity of thought set in an orderly arrangement before my eyes, ready to be converted. How pleasing not to have to labor over metaphors, similes, or symbols, but to have the very words set before me in all their glory, waiting to be translated. But there's the rub. Ignoring the difficulty of understanding the precise intention or layers of meaning Dante presents even to Italian readers, after we have found the English words that communicate his thought, we have to ponder whether the sound of the words expresses and reinforces their meaning.

\section{'But There's the Rub'}

Except for Latinate words such as maestro/master, Italian and English are often very far apart. For example, the Italian word 'fiamma' opens up at the end like a flaming fire indeed, while our English 'flame', although a cognate, closes in on itself with an $/ \mathrm{m} /$-sound as if it were dying out. Thus a poet, translating from Italian into English, must labor not only to match Dante's meaning, but also to select the word that sounds like it, or at least does not contradict its essential meaning.

Another problem is that the 'dictionary' equivalent of a word is not always reliable in conveying the nuances of meaning from one language to another. In poetry, the connotations surrounding a word are as important as its precise denotation. The tone or mood of a word is part of what is communicated. In addition, the conscious or unconscious associations we bring to a word may differ from one language to another, varying with the different literary or historical associations evoked. For example, the phrase I used earlier: 'there's the rub', familiar to English-speaking people as an often repeated phrase from Hamlet's soliloquy, has no literal equivalent in Italian. The dictionary equivalents of 'to rub', such as 'fregare', 'sfregare', 'strofinare', and 'stropicciare', even if changed into a noun, do not apply here. We must resort to something like: 'qui sta il punto' to render the meaning.

\section{The Stumbling Block of Rhyme}

Considering these and the many other problems that arise in going from one language to another, I think it foolhardy to add the even greater stumbling block of rhyme to the exacting task translators face. Important as the rigid rhyme scheme 
is to the original, it seems to me that any attempt to introduce terza rima, or some aberrant form thereof, in translating the work into English is doomed to failure.

While most of my examples will be taken from the pages of translation distributed for discussion at the conference, I came across the one found below while casually looking through a poetic translation of Purgatorio. What caught my eye was the awkwardness in the word order of the last line of the tercet:

[...] the true company that had come

at first between the griffin and it,

turned, as to their peace, to the chariot,

$[\ldots]$ la gente verace,

venuta prima tra 'l grifone ed esso,

al carro volse sé come a sua pace;

(Purg. 30, 7-9)

Before checking Dante's Italian, I assumed that the writer must have followed the exact word order, risking such awkwardness to achieve greater accuracy. To my surprise I found that Dante's word order is the same as the one natural in English: 'turned to the chariot as to their peace.' In addition, ending on the word chariot undermines Dante's reason for ending the tercet on the word 'pace'. The important concept here is not that the company turns to the chariot, but that the chariot represents 'peace' to them, and shows the intensity of their faith, that in turning to the chariot, they shall find peace in turning to God. Dante deliberately ends on 'pace' not only for the sake of rhyme here, but because this is the word containing and expressing the central concept of the entire tercet. That word, that idea, lingers with the reader when placed at the end of the line or tercet, in a way it cannot, if it is lost in the middle of the line.

Why then does the translator end on 'chariot'? I had leafed through the translation without being aware of any rhyme scheme. In search of an explanation, I studied it more closely and, I think, found the answer. Although there is no readily discernible rhyme scheme in this translation, there seems to be an occasional attempt to have line endings use words that end in the same, or similar, sound or consonant, but in no regular or predictable pattern as, for example, in the tercets preceding and following the stanza quoted above. The last words in the first 27 lines are: 'heaven', 'rising', 'sin' // 'was', 'does', 'port' // 'come', 'it', 'chariot' // 'Heaven', 'Lebanon', 'him' // 'sounds', 'one', 'again' // 'chariot', 'hundred', 'life' // 'comes', 'them', 'lilies' // 'day', 'east', 'rest' // 'shaded', 'it', 'it' etc. (Purg. 30, I-27). Thus, we find that for the sake of rhyming it and chariot, the author distorts the Italian word order, as well as the English idiom. It hardly seems worthwhile. 


\section{Rhyme's Deeper Significance}

Robert Pinsky, as is evident from his translation of the beginning lines of the Inferno, does follow the terza rima pattern. ${ }^{\mathrm{I}}$ But since English lacks the easy access to rhyming words abundant in Italian, he too is forced to resort to slant rhymes or to matching final consonant or vowel sounds, with a rare, occasional use of true rhyme.

Nel mezzo del cammin di nostra vita mi ritrovai per una selva oscura, ché la diritta via era smarrita.

Ahi quanto a dir qual era è cosa dura esta selva selvaggia e aspra e forte che nel pensier rinova la paura!

Tant' è amara che poco è piú morte: ma per trattar del ben ch'i' vi trovai, dirò de l'altre cose ch'i' v'ho scorte.

Io non so ben ridir com' i' v'intrai, (Inf. I, I-IO) [Ill. I, Inferno I]

Midway on our life's journey, I found myself In dark woods, the right road lost. To tell About those woods is hard - so tangled and rough

And savage that thinking of it now, I feel

The old fear stirring: death is hardly more bitter.

And yet, to treat the good I found there as well

I'll tell what I saw [...]

$$
\text { (Inf. I, I-7) [Ill. I, Inferno I] }
$$

As is shown above, the /f/ ending of myself is 'rhymed' with the final /f/ sound in rough. The rhyme of tell from the first stanza is picked up as feel and well in the next stanza, giving us a rare true rhyme in tell and well. The word bitter will become part of a 'bitter : enter : blunder' scheme, followed by the rhyming of 'sleep : stop : up' and 'valley : already : journey'. But in order to place the needed rhyming words, such as they are, at the end of each line, Pinsky is unable even roughly to approximate the lines of Italian given on the facing pages. Thus, from the very 
beginning, 9 lines of Italian are rendered as 61/2 lines in English, ending the first canto with a gallop of Iog lines of English versus the 136 lines written by Dante.

But something more important than the confusion of the reader, whose weak knowledge of Italian makes him rely on a facing page and line numbers to follow the meaning, is at stake here. I remember once talking to Richard Wilbur about why he so frequently and so beautifully uses rhyme in his work. His answer was that since the last word of a line is the most important word to the reader, using a rhyme word makes it linger even longer in the mind and ear. Dante, of course, knew that. The Inferno begins with the following as the last rhyming words of the first six lines:
vita
oscura
smarrita
dura
forte
paura

These line endings, as translated by Pinsky, read:

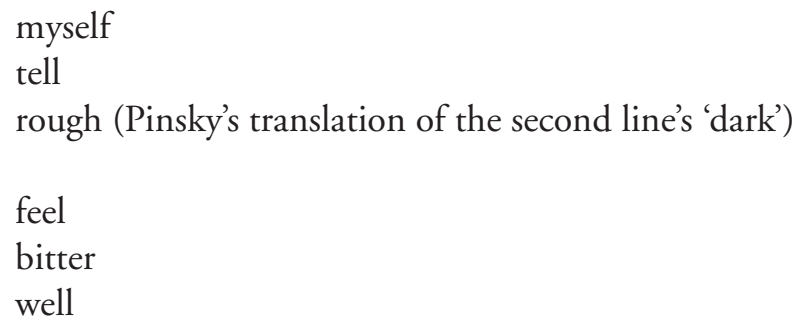

'Myself', 'tell', 'rough', 'feel', 'well' are not the words that express or focus the basic thought of those lines. The only good word that has the power and bite suitable to the passage and to Dante's own endings is the word 'bitter'.

\section{Problems of Diction}

Other modern writers, in translating a poem written in early fourteenth-century Italy, choose to use nineteenth-century poetic diction to render the work into English. While we may enjoy and understand the poems Keats and Shelley wrote, we no longer think, speak, or write their way, nor do our poets. In the fourteenth century, Dante wrote in the Italian of his time. We are therefore obligated to translate his Italian into the English of our own time. 
Dante, while following some poetic traditions in his work, also rebelled by writing his great opus in Italian, not Latin. In addition, he used many voices and styles within this one work, a fact often overlooked even by sensitive translators. His rhetoric shifts depending on his subject. The stark poetic simplicity of the opening stanzas may give way to the complicated rhetoric of philosophic or theological discussion, a political harangue may be interrupted by violent invective, a moment of remembered love be summoned by an image of doves returning to their nest, and so forth. The best way to catch the mood of the poem at any given moment is by being as true as possible to the literal text. Among the examples given in the handout is Mark Musa's translation of the opening lines:

Midway along the journey of our life

I woke to find myself in a dark wood,

For I had wandered off from the straight path.

How hard it is to tell what it was like,

This wood of wilderness, savage and stubborn

(the thought of it brings back all my old fears), (Inf. I, I-6) ${ }^{2}$

Musa begins by being literal and conveying the stark harshness of the scene. But then, instead of rendering 'selva selvaggia e aspra e forte' he gives us 'a wood of wilderness', creating a more poetic phrase with two nouns instead of the stark original, which gives us a noun followed by three adjectives, although he does capture the repetition of sound in 'selva selvaggia' with his 'wood of wilderness'. Why he chose to put the next line in parenthesis, which seems to indicate its lack of importance, is also puzzling, since the entire work is based, as Dante insists many times throughout, on this very memory of prior events.

Musa also veers from the original in introducing the word 'old', for which Pinsky also felt the need: 'I feel the old fear stirring [...].' By removing the fear into a distant past, both translators lose the immediacy and power Dante achieves with his simple 'la paura'. For Dante and his readers that fear is there, even as he writes. As I tell my poetry writing students, one good noun, and 'paura' is one, is worth more than a noun that needs to adorn itself with adjectives.

\section{Longfellow's Merits}

Although I have spoken against recent translations that erroneously attempt to give us a sense of Dante's rhetoric by using nineteenth-century poetic diction, I have nothing but praise for Longfellow's nineteenth-century translation. ${ }^{3}$ In more or less regular unrhymed iambic pentameter, it is a perhaps surprisingly accurate version of the text. Its only failures occur when Longfellow fails to render the rhetorical variety of Dante's 
language, as many modern translators also do. For example, toward the end of canto 2I, that celebrated version of medieval diablerie, with 'seething pitch' and winged 'dark devils' with tails (their leader is called Malacoda) tormenting sinners with their pitchforks, Dante uses colloquial, vulgar, strident language to convey not only the ugliness of the scene, but also the protagonist's terror. Here, while the original Italian becomes distraught and choppy, Longfellow proceeds at a professorial majestic pace:

«Omè, maestro, che è quell ch'i' veggio?», diss' io, «deh, sanza scorta andianci soli, se tu sa' ir; ch'i' per me non la cheggio.

Se tu se' sí accorto come suoli, non vedi tu ch'e' digrignan li denti e con le ciglia ne minaccian duoli?».

(Inf. 21, 127-I32)

'O me! what is it, master, that I see?

Pray let us go,' I said, 'without an escort,

If thou knowest how, since for myself I ask none.

If thou art as observant as thy wont is,

Dost thou not see that they do gnash their teeth,

And with their brows are threatening woe to us?

(Inf. 21, I27-I32) [Ill. 2, Inferno 22]

While the gnashing teeth are effective, the magisterial pace does not convey Dante's choppy rhythm here, nor prepare us for the end-line: 'ed elli avea del cul fatto trombetta' ('and he had made a trumpet of his asshole', Inf. 2I, I39).

Dante's style changes with different speakers and settings, and the translator must adjust his style to suit that variety. Francesca's mode in telling of the love that brought her to hell, is very different from the tone Ulysses uses in recalling how he inspired his men to follow him to the ends of the earth. Bertran de Born, holding his head up like a lantern as he tells his sin, has a voice very different from Ugolino's expression of pain and vicious fury. Language and mood shift with the shifting canvas. The simile of the arsenal in Venice as the workmen 'caulk their unsound ships' with 'viscous pitch' which introduces the scene devoted to the devils of barratry is different in language and mood from the 'hoarfrost' image of a country scene evoked to describe the protagonist's feelings of relief at seeing Virgil smile again.

Translating Dante is a joy and a challenge, forcing the translator into a better understanding of the complexity and skill of the original and the labor of getting just a small part of it right. 


\section{The Poet Translated by American Poets. in Search of the Perfect 'Trasmutazione Musaica'}

RONALD DE ROOY

E però sappia ciascuno che nulla cosa per legame musaico armonizzata si può de la sua loquela in altra transmutare, sanza rompere tutta sua dolcezza e armonia.

Therefore everyone should know that nothing harmonized according to the rules of poetry can be translated from its native tongue into another without destroying all its sweetness and harmony.

$(\text { Convivio I, VII, I4) })^{\mathrm{I}}$

In the most recent flux of English and American translations of Dante's Comedy, there is a clear tendency towards translations made by poets. This trend coincides with a renewed, strong interest in translations in terza rima. Within the period I994-2002 twelve English and American canticles were published, ten of which were translated - partially or totally - by poets. What's more, seven of these canticles adopt a certain type of terza rima as their metrical solution. ${ }^{2}$

\section{Dante and the Modern Poets}

These close ties between Dante and twentieth-century poets are by no means a new or unknown phenomenon. During the entire twentieth century, in fact, numerous English-speaking poets and writers showed considerable interest in Dante and in his work. A multifaceted overview of their views can be found in The Poets' Dante (200I), ${ }^{3}$ an entire volume dedicated to the many theoretical, critical, philosophical and existential responses to Dante's work by (mostly English and American) twentieth-century poets. In the first part of this book, the editors brought together several classical essays that play a fundamental role both in the history of modern Dante reception outside Italy and in the history of modern Dante translations. Famous poets like T.S. Eliot, Ezra Pound, Osip Mandelstam, Eugenio Montale and Seamus Heaney share their insights on Dante's influence on their own poetry and on modern poetry in general. The second part is crammed with essays by more recent generations of English and 
American poets and poetesses who reflect on their own bonds with the great Florentine poet.

The results of a similar project were presented in 1993, only eight years earlier. Under the guidance of Daniel Halpern, Ecco Press published a volume entitled Dante's Inferno. The only difference between the projects was that here the poets' responses to Dante's Comedy were presented as translations. ${ }^{4}$ Taken together, these translations by twenty contemporary poets make an Inferno sui generis, extremely varied, and polyphonic. Here again the eye is caught by the work of several famous poets like Seamus Heaney (Inf. I-3), Robert Pinsky (Inf. 20, 28), Richard Wilbur (Inf. 25), and W.S. Merwin (Inf. 26-27).

Other Dante translations by poets came out in rapid succession: one year later, in 1994, Robert Pinsky, the future 'poet laureate' of the United States, published his Inferno, in many ways a truly innovative translation that was highly appreciated by American readers. ${ }^{5}$ In 1996, Peter Dale published with the London editor Anvil his translation of the entire Comedy. ${ }^{6}$ Only a few months later, in February of the following year, the English journal Agenda published a special issue, Dante, Ezra Pound and the Contemporary Poet, in which several poets presented their renderings of entire cantos and fragments of the Comedy..$^{7}$ In 20oo, jubilee and 7ooth anniversary of Dante's journey in the otherworld, American publishers presented yet two more important translations: a Purgatorio by the poet W.S. Merwin ${ }^{8}$ and an Inferno translated and commented on by Dante scholar Robert Hollander in close collaboration with his wife, the poetess Jean Hollander, who took up the task of revising and rendering the results more lyrical.9 Therefore, this last translation has to be considered a poet's translation as well. This long series of poets translating Dante has its final landmarks, at least for the time being, in Michael Palmas translation of the Inferno, published in the spring of 2002, ${ }^{\mathrm{IO}}$ and the Hollanders' Purgatorio, published in February 2003. ${ }^{\mathrm{II}}$

\section{Terza Rima or Nothing?}

Many modern poets, especially those in the English-speaking world, have been irresistibly fascinated by Dante's terza rima while at the same time being enormously frustrated by it:

Asked for an example of terza rima, readers of English poetry will point first to Shelley's 'Ode to the West Wind.' Yet this beautiful plotless paean gives only the faintest notion of the form's energy and variety in the hands of the inventor. At the practical level it works as a No Trespassing sign, protecting the text. A copyist's pious interpolation or unthinking lapse would at once set off the alarm. At the level of pleasure no verse form moves so wonderfully. Each tercet's first and third line rhyme with the middle one of the preceding set and enclose the new rhyme-sound of the next, the way a scull outstrips the twin, already dissolving oarstrokes that propel it. As rhymes interlock throughout a canto, so do incidents and images throughout the poem. ${ }^{12}$ 
It can be said that the translator's most basic choice at the level of expressive means will to a large extent not only determine the stylistic make-up but probably also the positive or negative outcome of any translation of the Comedy. ${ }^{13}$ This basic choice of expressive means can be located on a scale that moves from prose, through 'poetic' or rhythmic prose, free verse, blank verse, slant rhymed tercets, all the way to fully rhymed terza rima. According to Theodore J. Cachey, this scale of expressive means also implies an aesthetic hierarchy,

che va da un polo che si può definire poetico ad un altro che si può dire ermeneutico: la prosa rappresenta il mezzo ideale per mantenere un'adesione al significato letterale, mentre al polo opposto la scelta della terza rima mantiene gelosamente il carattere poetico dell'originale ${ }^{\mathrm{I} 4}$

When it comes to rendering the Comedy's poetic qualities in his translation a poet is - in theory and compared with ordinary mortals - expected to benefit greatly from his special talents and skills as an expert 'fabbro' of his 'parlar materno'. A terza rima translation is - in theory - the most poetic result a translator could achieve. On the other hand, as is well known, any terza rima translation involves many risks and drawbacks, not to mention countless difficulties. In fact, it is hard, almost impossible, to make a terza rima translation that is also 'honest' and faithful to the original text.

In the past, there have often been heated discussions about the use of terza rima, discussions in which participants maintained their rigid views obstinately. Particularly in the first half of the twentieth century, there was an almost religious battle between modernist, 'creative' translators on the one hand and academic, 'precise' translators on the other. Let us call to mind one of these bold perspectives: in the introduction to her widespread terza rima version of the Inferno, Dorothy Sayers asserts very determinedly that for any translator of Dante's Comedy the choice at the level of expressive means is very simple: 'terza rima or nothing'. ${ }^{\text {Is }}$ If only matters were that simple...

One year later, in 1950, no less a person than T.S. Eliot gave his opinion on this delicate matter. In his famous speech What Dante Means to $M e,{ }^{16}$ Eliot tones down the sharpness of Sayers's assertions, stating that (in comparison with Italian) English is in fact poorer in rhyming words; that in English verse (again in comparison with Italian) rhyming words tend to receive more emphasis, and furthermore that a long poem in terza rima would have a certain anachronistic quality in the context of twentieth-century poetry. ${ }^{17}$

In attempting to get closer to Dante's meter in his own poetry, Eliot comes upon the problem of finding an equivalent of terza rima without rhyme. His own solution, in Little Gidding (Four Quartets), was to adopt an alternation of 'unrhymed masculine and feminine terminations, as the nearest way of giving the light effect 
of the rhyme in Italian. ${ }^{\text {'18 }}$ When one imitates Dante, 'the slightest vagueness or imprecision is immediately noticeable' ${ }^{19}$

However, this does not alter the fact that Eliot is enormously fascinated by terza rima and that he considers it the vital essence of Dante's poem. Therefore, he cautiously affirms that a rhyming terza rima translation of the Comedy is probably 'less unsatisfactory [...] than is blank verse'. ${ }^{20}$ Dante thought in terza rima, and an ideal translation should be 'as nearly as possible in the same thought-form as the original'. ${ }^{21}$ On the other hand, however, Eliot remains perfectly aware that this kind of translation is virtually impossible to achieve, because of the fact that

no verse seems to demand greater literalness in translation than Dante's, because no poet convinces one more completely that the word he has used is the word he wanted, and that no other will do. ${ }^{22}$

The ambivalence in Eliot's speech (i.e. his enormous admiration for Dante's meter vs. his awareness of its inimitability) is a reflection of the demarcation between modernism (with its clear preference for terza rima translations) and the postwar period in which, until recent years, prose and blank verse prevailed in Dante translations. When looking at the overall picture of Dante translations in the postwar period, what strikes one most is that Sayers's terza rima translation remained for quite some time somewhat of an exception: it was the last product of the modernist tendency towards terza rima. ${ }^{23}$ After Sayers, English and American translators of the Comedy have shown a preference for prose and free or blank verse.

The motives behind this preference are clear. The major risk attached to the use of terza rima in a language like English (or Dutch for that matter) is that the process of appropriation and transmutation of the original text becomes too aggressive. In other words, one runs the risk that the tone, the rhythm, the syntax, and the lexicon of the translation are heavily deformed by the constraints imposed by the endless chain of triadic rhymes. Prose - the favorite means of expression for 'hermeneutic' translators like Charles Singleton ${ }^{24}$ and Robert Durling 25 - or blank verse ${ }^{26}$ constitutes more cautious translational strategies that in general show more respect towards the original text.

\section{The Comeback of Terza Rima}

As I have said before, a change of paradigm seems to have occurred in the last decade of the twentieth century, and particularly in the above-mentioned translations by several poets, like Richard Wilbur, Robert Pinsky, Peter Dale, W.S. Merwin, Jean Hollander, and Michael Palma. Among the translations by these poets, prose versions are lacking all together, and the tendency towards blank verse 
is still strong, ${ }^{27}$ but the remarkable novelty seems to be a comeback, at first sight rather fruitful, of various forms of terza rima.

Of the mentioned renderings by poets, several are written in fully rhyming terza rima: in 1993 the poet-translator Richard Wilbur dedicated himself to a single canto of the Inferno; in 1996 Peter Dale published his version of the entire Comedy, and more recently, in 2002, Michael Palma published an Inferno in terza rima. 'Poet laureate' Robert Pinsky chose to adopt a personalized type of terza rima, largely based on consonantal slant rhyme. ${ }^{28}$ Several other poets-translators have developed even more moderated and modified types of terza rima, like the one in which only the tercet's first and third lines contain rhymes or assonant rhymes. Seamus Heaney successfully applied this solution in his version of the first three cantos of the Inferno. ${ }^{29}$

\section{Appropriation, Transmutation... Translation!}

To show the many difficulties encountered by these daring poets-translators, it might be enlightening at this point to perform a small comparative analysis on several of the recently published terza rima versions. The bolgia of the thieves is interesting to focus on, as it is emblematic of aggressive and painful appropriations and transmutations. The fact that Richard Wilbur translated only one canto, namely Inferno 25, makes this particular bolgia an even more valuable and interesting subject of analysis. Wilbur did not proceed after this canto because he considers translating the Comedy or even only the Inferno too laborious and too demanding a task for a poet of his age.

The bolgia of the thieves belongs to the most horrible and intriguing experiences of the eighth circle. Dante dedicates two cantos to this bolgia, Inferno 24 and 25. The thieves run naked in a valley that is filled with all kinds of serpents, which, according to medieval bestiaries, are among the lowest and ghastliest animals on earth. In canto 24 Dante meets one of the most impious and despicable characters of the whole Comedy, the bestial thief Vanni Fucci who even has the nerve to defy God by making an obscene gesture towards heaven. In these two cantos, the contrappasso seems to become an art in itself: the serpents, already symbols of committing sins in secret, turn into thieves themselves: the serpents rob the thieves of man's most personal possession, his body.

Metamorphosis is the central theme of the entire bolgia, where Dante witnesses three 'science fiction'-like scenes. In canto 24 Vanni Fucci is bitten by a serpent, and this bite burns him up completely, reduces him to ashes, after which he's immediately reborn. In canto 25 Cianfa, who has taken the form of a serpent, clings tightly to Agnello, and together they make a monstrous hybrid creature. Finally, the narrative climax in this bolgia: the thief Buoso and the serpent Francesco exchange their bodies during a frightening mutual transmutation. 
The metamorphic appropriations and transmutations which take place in the bolgia of the thieves can be seen as allegorical visualizations of the very process of translating a text into another language, just like the 'zavorra' of the last bolgia is transmuted continuously and painfully into new identities, Dante's words are transmuted slowly and often painfully from Florentine into English.

For a long time the poet Richard Wilbur has been famous for his rare mastery in applying traditional meters and poetic forms, and he also enjoys great fame as a translator of Molière and Racine among others. ${ }^{30}$ As has been stated by Wilbur himself, Inferno 25 is a real challenge to any translator. An extremely difficult task faces the translator who both wants to maintain the terza rima and reproduce the incredible speed of changes that characterizes Dante's narration in this bolgia. Wilbur says in this respect

I also wanted to confront the canto's peculiar challenge, and see if I could not, while preserving the terza rima form, convey Dante at his most complex in the spare, plain Dantean manner. And there were other attractions as well: I wanted to do right by the great similes of burning paper and darting hedge-lizards, and by the elegant lines which recollect the metamorphoses in Lucan and Ovid. ${ }^{3 \mathrm{I}}$

A translator, and particularly a translator who uses terza rima, should therefore cling tightly to the original in order to transmute it into a poetic text in English. With a little effort, we might be able to see a metaphoric caricature of this textual embrace in the Dantean scene in which the thief Cianfa, in the form of a monstruous serpent, clutches Agnello, attempting to rob him of his human shape:

Ellera abbarbicata mai non fue ad alber sí, come l'orribil fiera per l'altrui membra avviticchiò le sue.

Poi s'appiccar, come di calda cera fossero stati, e mischiar lor colore, né l'un né l'altro già parea quel ch'era:

come procede innanzi da l'ardore, per lo papiro suso, un color bruno che non è nero ancora e 'l bianco more.

Li altri due 'l riguardavano, e ciascuno gridava: «Omè, Agnel, come ti muti! Vedi che già non se' né due né uno».

(Inferno 25, 58-69) [Ill. 3, Inferno 25] 
The next sections contain a brief analysis of the terza rima translations of this and other fragments by Richard Wilbur, Robert Pinsky, Peter Dale and Michael Palma. I will first give an impression of these four translations by focusing on tone, idiom, syntax, and narrative rhythm. In any terza rima translation, these aspects are at risk of becoming heavily deformed, because of the constraints imposed by the endless chain of triadic rhymes. Next, I will focus on some striking phonic patterns in the original text of Inferno 25 and on the ways in which these phonic patterns have been recreated in the four poetical translations. Finally, I will take some of the numerous semantic ambivalences of Dante's text and see how the poet-translators have dealt with them. I hope that this brief analysis will show the enormous difficulties encountered by these daring translators who, under the yoke of the rhyme chain, must often have felt like 'clowns following a ballet dancer'. ${ }^{32}$ On the other hand, it will become clear that some of these poets courageously face up to the extreme difficulty of their task and somehow manage to achieve a poetical translation that is both faithful and elegant.

\section{First Impressions: Tone, Idiom, Rhythm, Syntax}

\section{Richard Wilbur}

Let us consider first of all the translation of Richard Wilbur, who renders the quoted verses in an extremely powerful and poetic manner:

Never did ivy cling so to a tree as did that hideous creature bind and braid its limbs and his in pure ferocity; $\quad 60$

And then they stuck together, as if made of melting wax, and mixed their colors; nor did either now retain his former shade:

Just so, when paper burns, there runs before the creeping flame a stain of darkish hue that, though not black as yet, is white no more.

The other two cried out to him they knew, saying, 'Agnello, how you change! Ah me, already you are neither one nor two.'

It is really surprising how natural the tonality, the rhythm and the syntax have remained in the rhyming translation of this fragment. Wilbur has succeeded in avoiding one of the biggest risks of translating terza rima in a language like 
English (or Dutch for that matter): the risk that because of frequent syntactic distortions and far-fetched rhymes, too much stress falls on the rhyming words, and the verse rhythm becomes excessively monotonous. In this respect, one need only compare Wilbur's translation with that of Dorothy Sayers:

Ivy to oak so rooted never grew

As limb by limb that monstrous beast obscene

Clung him about, and close and closer drew,

Till like hot wax they stuck; and, melting in,

Their tints began to mingle and to run,

And neither seemed to be what it had been. ${ }^{33}$

Here we perceive a rather monotonous rhythm combined with distorted syntax; in the beautiful translation of Wilbur, on the other hand, the refined and repeated use of enjambment produces a faster pace and a successful mitigation of the rhyme pattern. Also with respect to content, Wilbur's version is surprisingly faithful to the original; the price he has had to pay for his courageous attempt to imitate the formal make-up of the 'poema sacro' is relatively small. There are only a couple of moments when the limitative force of the rhyme pattern manifests itself in Wilbur's translation: for example, the phrase 'in pure ferocity' (v. 60) makes a little less evident the parodic allusion to sexual embrace that is flirted with in the original description. ${ }^{34}$ Furthermore, because of the rhyme scheme the word 'shade' (v. 63) has been added, a word that is not appropriate in the extremely bodily context of this bolgia. While in other parts of the Inferno Dante's souls are ethereal and transparent, the thieves seem to have solid and firm bodies...

\section{Robert Pinsky}

The applauded version by Robert Pinsky, who translated the Comedy in a milder form of terza rima using an alternation of slant rhyme and normal rhyme, also reaches a poetically attractive result. In this translation, however, the reader's eye is caught first of all by the dazzling speed of the narration and its high readability. Indeed, these seem to be also precisely the less strong points of this translation: in the bolgia of the thieves, Dante's text surely is fast, but not this fast - in Pinsky's translation every single line contains an enjambment. Moreover, Dante's text is certainly not as easily readable as Pinsky's translation could lead us to believe: ${ }^{35}$ 
No ivy growing in a tree's bark sticks

As firmly as the horrid beast entwined

Its limbs around the other. Then, as if made

Out of hot wax, they clung and made a bond

And mixed their colors; and neither could be construed

As what it was at first - so, as the track

Of flame moves over paper, there is a shade

That moves before it that is not yet black,

And the white dies away. The other two

Were looking on, and cried, 'Ah me, now look

At how you change, Agnello! - already you

Are neither two nor one.'

Like Wilbur, this poet-translator succeeds in avoiding a too monotonous rhythm as well, an achievement that takes this translation an important step further than many previous translations in terza rima. Moreover, definitely in this fragment, Pinsky's translation stands out for its semantic faithfulness.

\section{Peter Dale}

In the translation by Peter Dale, on the other hand, the traditional negative consequences of translating in terza rima are more visible. His version is less faithful to the original - to the point that certain phrases turn out to be almost incomprehensible - and also its rhythm is slower and more monotonous:

Ivy was never rooted to a tree so true

As on the victim's limbs the monster wound

And intertwined his own, and to him grew.

60

As if of heated wax the then compound,

And mix their colours, so that neither one

Nor other seemed what first it had been found;

Thus paper, over flame, turns brown and dun

But not yet charred and black, and all the white

Retreats and dwindles out upon the run. 
The other two stood gazing on the sight

And cried: 'Ah me, Agnello, how you change!

You're neither one nor two nor yet unite.'

\section{Michael Palma}

The American poet Michael Palma has published the most recent terza rima translation of the Inferno. As a poet and as a translator Palma has always had a preference for traditional and formally 'closed' poetry (he also translated I Colloqui and other poems by Guido Gozzano ${ }^{36}$ ). Palma translates our fragment as follows:

Never did any strand of ivy bind

its clinging roots more closely to a tree

than the limbs of that disgusting beast entwined

60

round the soul's. The two seemed like hot wax to me

as their colors mingled and they were stuck tight,

and neither kept its own identity.

In the same way, when a paper is alight, ahead of the flame a dark hue starts to spread

that is not yet black but already no longer white.

The other two were watching, and they said:

'Alas, Agnello, how fast you are defaced,

neither two nor one, but something else instead.'

Compared to Wilbur and Pinsky this translation is less 'clung' to Dante's text - it will suffice, in this context, to indicate some semantic licenses obviously dictated by the rhyme scheme, like 'neither kept its own identity', 'how fast you are defaced' and 'but something else instead'. It should be mentioned too that Palma's narrative pace is somewhat slower than Pinsky's and Wilbur's. These last two poets-translators certainly make a very good first impression on the reader. Let us now expand our analysis of all four terza rima translations by focusing on their behavior towards some remarkable phonic structures and towards the semantic complexity of Dante's poetry.

\section{Beyond Rhyme: Phonic Features}

As mentioned before, a translator who respects terza rima runs greater risks of having to neglect not only the original text's content but also several of its form aspects: its accentuated phonic make-up for example. Generally speaking, a terza rima translator is forced to sacrifice many other formal elements, whereas a blank 
verse or prose translator has his hands much less tied. Let us return to the thieves and their violent appropriations.

Dante intensifies his narrative tour de force in the second half of canto 25, when he is describing not simply a metamorphosis, nor a fusion between a man and a serpent, but every single stage of a perfectly symmetrical mutual transmutation of a human being and a serpent. The narrative pace is still very high, images emerge in rapid succession, until a horrible climax is reached in which Dante superbly describes the reciprocal transmutation of the two heads (the thief's and the serpent's) and of the two tongues (the human and the forked one):

Quel che giacëa, il muso innanzi caccia,

e li orecchi ritira per la testa

come face le corna la lumaccia;

e la lingua, ch'avëa unita e presta

prima a parlar, si fende, e la forcuta

ne l'altro si richiude; e 'l fummo resta.

L'anima ch'era fiera divenuta, suffolando si fugge per la valle,

e l'altro dietro a lui parlando sputa.

Poscia li volse le novelle spalle, e disse a l'altro: «I' vo' che Buoso corra, com' ho fatt' io, carpon per questo calle.» (Inferno 25, 130-I4I)

The sound symbolism catches the eye (or ear) in the tercet I36-I38. Dante superbly mimes the serpent's hiss, by means of labiodental and fricative sounds ('L'anima ch'era fiera divenuta / suffolando si fugge per la $\underline{v}$ alle'). Through occlusive sounds he mimes the aggressive stutter of the thief who makes frantic efforts to regain his human language ('e l'altro $\underline{d i e t r o}$ a lui $p a r l a n \underline{d} \underline{s p} u \underline{t a}$.'). The same accentuated occlusivity is repeated in the first words actually pronounced by the ex-serpent: 'I' vo' $\underline{c h e}$ Buoso $\underline{c}$ orra, / $\underline{c o m}$ ' ho fatt' io, $\underline{c}$ arpon per questo $\underline{c}$ alle.' (vv. I4O-I4I). This stressed occlusivity might very well be a distinguishing feature of the thieves' language; in this respect let us call to mind the famous last words of

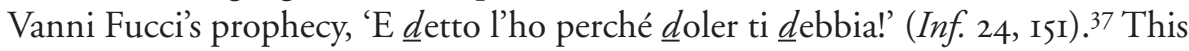
phonic contrast between the aggressive occlusivity of the human thief and the fricativity which is characteristic of the serpent had already been anticipated in the lines of the preceding tercet (133-135): 'e la lingua, ch'avëa unita e presta / prima a parlar, si fende, e la forcuta / ne l'altro si richiude; e 'l fummo resta.' Here already occurs an efficient contrast between two phonemes, i.e. /p/ and /f/. 


\section{Richard Wilbur}

In Wilbur's version these lines still have a very distinct musical appeal, but the phonic richness of Dante's text could not be saved. In the quoted fragment the most striking phonic structures which remind us of those in Dante's original have been underlined and italicized:

The prone one thrust his jaws out like a snake, and at the same time drew his ears inside, as a snail retracts its horns for $\underline{\text { safety's sake, }}$

And cleft his tongue, that once was unified and shaped for speech. Then, in the other's head, the forked tongue healed, and the smoke could now subside.

The soul that had become a beast now fled hissing away; the other, who had begun to speak in sputters, followed where it led,

Yet turned his new-made shoulders toward the one who lingered, saying, 'Buoso shall crawl through this stony terrain awhile, as I have done.'

\section{Robert Pinsky}

Compared to that of Wilbur, Pinsky's version - which in this fragment as well is characterized by its excessive narrative speed - succeeds much better in evoking the pronounced sound symbolism of the original lines. Although less systematically than Dante, the American poet surprisingly repeats the ear-catching contrast between occlusivity and fricativity:

He that lay prone propelled his nose and face Forward, and shrank his ears back into his head

As a snail does its horns. The tongue that was

Whole and prepared for speech was split instead And in the other the forked tongue formed one piece: And the smoke ceased. The soul that had been made

A beast fled down the $\underline{v}$ alley with a his $s$; The other, speaking now, spat after it, Turned his new shoulders on it to address 
The third, and said: 'I'll have Buoso trot

On all fours down this road, as I have done!'

\section{Michael Palma}

The most emphasized and most interesting phonic structures, however, can be found in Palma's translation, which shows a very refined ear for the original's musicality. Apart from the stressed fricativity, this poets-translator managed even to create a kind of fused timbre in the three central rhyme triplets of this passage (/ajd/ - / It/ - / $\mathrm{ed} / \mathrm{Id})$ :

Meanwhile, the one who had fallen started to push out a snout and pull his ears inside, as a snail when it retracts $\underline{\text { its }}$ horns will do.

His tongue, which had been fit for speech and wide, now forked. The other's tongue, which had been split, became one. And I saw the smoke subside.

The new-formed beast went scampering through the pit, emitting hissing noises as it fled.

The other one was spitting after $\underline{\text { it. }}$

He turned his new shoulders toward the third and said:

'Now I'll let Buoso have the degradation

of running on six legs the way I did.' ${ }^{38}$

\section{Peter Dale}

Finally, Peter Dale's translation of this fragment. Compared with the other three poetical translations with regard to phonic structures, Peter Dale's can be considered the flattest, most soundless, version:

The one now prone extends his pointed face

And draws his ears back inside his head,

As snails will draw their horns back into place.

His tongue, once joined and apt for words, instead

Divides and, in his opposite, the split

Within the fork unites - and the smoke is fled.

The soul, that now was brutish, hissed its spit

And fled along the vale; the other bawling

And spitting at its back, then turned from it 
His novel shoulders: 'I'll have Buoso crawling

On all fours down this road,' he said, 'the same

As me!' towards the other shade then calling.

\section{Semantic Nuance and Ambivalence}

Translating a literary text always implies making choices, interpreting, and therefore continuously reducing the original text's ambivalence and semantic richness. In an essay on the extreme difficulties of translating Dantean ambivalence, Tibor Wlassics asserts that no translator can avoid this ambivalence, which in the case of the Commedia leads to making interpretive choices in every tercet, indeed almost in every line. ${ }^{39}$ In the first canto of the thieves, we find the line 'ma chi parlava ad ire parea mosso' (according to Petrocchi's reading), which in a vast majority of manuscripts reads 'ma chi parlava ad ira parea mosso' (Inf. 24, 69). This line is one of several fascinating cases in which both solutions (i.e. 'ire' and 'ira') seem equally valid. Another famous example cited by Wlassics is that of the Harpies which in the wood of the suicides 'fanno lamenti in su li alberi strani' (Inf. I3, II5): strange laments? strange trees? or strange laments and strange trees? All solutions seem equally plausible, but the translator is often forced to choose only one of them.

Let us take a quick look at ten examples of syntactic and semantic nuances and ambivalences in Inferno 25 and see how the poets-translators have dealt with them. Were they aware of the ambiguities in the original text, have they tried to maintain them in their translation, or were they forced to compromise?

\section{I) 'e un'altra [serpe] [li s'avvolse] a le braccia, e rilegollo' (v. 7)}

'Rilegare' can mean tie securely, but it can also mean tie again. In fact, all thieves had their hands tied, but Vanni Fucci, immediately after having returned to his human shape, took advantage of his untied hands to make an obscene gesture against God. The poets-translators oscillate between these two tying options. Only Palma ('retied [...] with so tight a fit') seems to be perfectly aware of the slight ambivalence in the word used by Dante and has found a way to make explicit both possible meanings in the English line.

I. and tied a knot / [...] again (Wilbur)

2. ... went around his arms to snake

Them tight (Pinsky)

3. Another wound around his arms... (Dale)

4. and another retied him with so tight a fit (Palma)

2) 'venir chiamando: 'Ov' è, ov' è l'acerbo??' (v. I8)

'Acerbo' ('raw') in this context can be understood metaphorically as 'cruel' or 'violent' 
(cf. also Inf. 22, 32: 'e quanto mi parea ne l'atto acerbo', which is said of the first Malebranche Dante sees). Although the vast majority of modern comments gives in fact metaphorical meanings like 'impious', 'cruel', or 'arrogant', all poets-translators (with the exception of Dale whose translation, however, is too remote from the original) tend to a rather literal interpretation - perhaps influenced by Robert Hollander's beautiful interpretation of this passage. ${ }^{40}$

I. 'Where has that half-cooked sinner gone?' (Wilbur)

2. 'Where is he? Where is the bitter one?' (Pinsky)

3. 'Where is he? Where's that surly clod?' (Dale)

4. 'Where is he, where's the unripe spirit gone?' (Palma)

3) 'Com' io tenea levate in lor le ciglia' (v. 49)

Literally, this plastic phrase depicts the facial expression of someone who looks in a very intense and intent manner, opening his eyes as much as possible without blinking at all. Wilbur and Dale translate this line too weakly ('I watched...'); Palma has the best translation.

I. I watched... (Wilbur)

2. While I was staring... (Pinsky)

3. as I watched them (Dale)

4. As I fixed upon those three with a steady stare (Palma)

4) 'come procede innanzi da l'ardore, per lo papiro suso, un color bruno che non è nero ancora e 'l bianco more.' (vv. 64-66)

'Papiro' means white paper, but it is also the taper of a candle. However, the second meaning seems less probable because, although 'forse il senso del termine più comune allora', ${ }^{4}$ it does not fit well into the semantic context (the flame in the simile moves 'suso', i.e. upwards). All poets-translators choose the most neutral rendering 'paper', whereas 'parchment' might have been a little more appropriate.

5) 'Ogne primaio aspetto ivi era casso:

due e nessun l'imagine perversa parea; e tal sen gio con lento passo.' (vv. 76-78)

'Perversa' in this context can mean 'altered', 'degenerate', 'non-natural' and also 'evil'. The English term 'perverse' expresses only the second and third meanings. In the light of the mentioned ambivalence 'perverted' might have been a more suitable translation. 
I. and the monstrous form that was and was not they (Wilbur)

2. A perverse shape, with both not what they were,

Yet neither (Pinsky)

3. Neither, yet both, the perverse image merged (Dale)

4. a perverse thing that was both and neither one (Palma)

6) 'sì pareva, venendo verso l'epe

de li altri due, un serpentello acceso

livido e nero come gran di pepe’ (vv. 82-84)

'Acceso' stands for 'burning', but it can be understood metaphorically as well, i.e. 'infuriated', a semantic ambiguity made explicit only by Palma. In reality, 'fiery' on its own (Wilbur, Pinsky) also implicitly expresses the semantic duplicity of 'acceso'.

I. a little reptile, fiery-hot (Wilbur)

2. a fiery little serpent (Pinsky)

3. a little reptile $[\ldots]$, in fury rash (Dale)

4. a little serpent in a rage, / as fiery and as black as pepper (Palma)

7) 'Taccia Lucano omai là dov' e' tocca del misero Sabello e di Nasidio, e attenda a udir quel ch'or si scocca.' (vv. 94-96)

A rather powerful metaphor, although by no means unusual in Dante's language: the narration that follows is like an arrow flying from the poet's bow. Pinsky and Palma fully respect this semantic detail, translating literally:

I. but listen now / to what I saw. (Wilbur)

2. [...] till he has learned

What I will let fly next. (Pinsky)

3. To hear what next my verses shall unfold. (Dale)

4. and let him wait to hear what is sent forth next. (Palma)

8) 'L'anima ch'era fiera divenuta, suffolando si fugge per la valle, e l'altro dietro a lui parlando sputa.' (v. I38)

Spitting was considered 'un gesto di ostilità verso l'altro, in quanto la saliva umana era ritenuta nel Medioevo nociva ai serpenti'. ${ }^{42}$ More plausible and more interesting, however, would be an interpretation according to which the thief spits while talking, because he has not fully recovered his human speech. The difficulty in 
translating this line lies in deciding the ex-serpent's main activity: does he speak or does he spit? Wilbur gives the most satisfactory translation ('speak in sputters'), Pinsky and Dale separate the two activities, and Palma chooses to omit 'speaking' alltogether.

I. the other, who had begun / to speak in sputters (Wilbur)

2. The other, speaking now, spat after it (Pinsky)

3. the other, bawling / and spitting at its back (Dale)

4. The other one was spitting after it. (Palma)

9) 'Così vid'io la settima zavorra

mutare e trasmutare; e qui mi scusi

la novità se fior la penna abborra.' (vv. I42-I44)

If my pen does not go astray (abborracciare: 'fare disordinatamente, alla meno peggio, in gran fretta', GDLI), a little bit ('fior'). This line might benefit from an ironic reading: earlier, Dante has amply demonstrated that he knows how to tell and describe these miraculous metamorphoses better than Ovid and Lucan, his great ancient predecessors. Unfortunately, the small addition 'fior' has not been translated by the poets-translators, thus losing the possible irony.

I. ... if my pen has gone amiss. (Wilbur)

2. ... may its strangeness excuse my pen, If it has tangled things. (Pinsky)

3. if my pen / Errs (Dale)

4. .... if I err in my narration. (Palma)

Io) 'E avvegna che li occhi miei confusi fossero alquanto e l'animo smagato,' (vv. 145-146)

The first meaning of 'smagato' in this context is 'profondamente emozionato e turbato, sconvolto, sbigottito' (GDLI), but it can also mean 'indebolito, fiaccato; prostrato'(GDLI) (cf. Old French esmayer and Provençal esmaiar): 'è verbo frequentissimo nell' italiano antico e vale propriamente «indebolire, perder o toglier le forze»' . 43 'Therefore, 'smagato' can be translated also as weakened, deprived of its power (and therefore remaining bewildered). Pinsky and Palma limit its meaning to 'bewildered', whereas Wilbur and Dale introduce 'dismay', which according to Singleton's commentary is 'the English cognate, from the OFr esmaier'.

I. my thoughts were fuddled by dismay (Wilbur)

2. My mind somewhat bewildered (Pinsky) 
3. And mind dismayed (Dale)

4. My mind had been bewildered (Palma)

Earlier we saw that Richard Wilbur and Robert Pinsky are capable of reproducing faithfully the overall meaning of Dante's text in a rhyming translation. They both prove to be very good as well at recreating many of the semantic nuances and ambivalences in Dante's original text. It is remarkable that Michael Palma stands out for his accurateness in making explicit especially Dante's semantic finesses.

\section{By Way of Conclusion}

Until recently, I believed a terza rima translation of Dante's Comedy would always leave too much to be desired. After having read and analyzed the beautiful translations by Wilbur, Pinsky and Palma, I have become more optimistic about the possibility of a terza rima translation, which is not only poetical but also acceptably faithful to the original text. Which secrets are hidden behind the success of these fascinating translations? First of all, these poets-translators will certainly have profited greatly from their own long experience with traditional and 'closed' poetic meters, which in certain ways are comparable to Dante's terza rima. Moreover, they have also had the benefit of a solid tradition of American and English Dante studies and, above all, of an extremely rich tradition of English Dante translations, among which there are also many attempts in terza rima. Finally and perhaps most importantly, their modest, submissive and reverent attitude stopped them from producing an aggressive and deforming appropriation of Dante's text, with the exception of Pinsky who unfortunately tends time and again to magnify certain textual elements at the expense of many others. In particular, Richard Wilbur will have benefited also from his patience of Job and from his genuine awareness that an acceptable terza rima translation requires an enormous amount of time. In an interview with Peter Dale he said about this:

Various people [...] thought well enough of my canto to raise the possibility of my doing Dante, or his infernal portion at any rate, in toto. Two things have deterred me. It took me a very long time to do Canto xxv, and preserving the form of the original (which seemed to me obligatory) involved such fascinating difficulties that I often felt I was on a suicide mission. At the age of seventy-nine, I am not sure that I have the time to win thirty-three more battles of the kind, let alone ninety-nine. And so for the present I am hanging back, and waiting perhaps for an access of folly. ${ }^{44}$

The mention of a 'suicide mission', the allusion to a (maybe desirable) 'access of folly', and also his partly concealed fascination with Inferno 26,45 bring this extremely modest and patient poet-translator imperceptibly in Ulysses' realm of hubris. An interesting combination, indeed, because the ideal terza rima translator would in 
fact need Ulysses's fearlessness, yet intermingled with a full measure of prudence, submissiveness and modesty.

But even if he could dispose of the very best navigation system, the best translation strategy and the best of intentions, such an ideal translator will always have to sail between the Scylla of the dazzling rhyme chain and the Charybdis of semantic honesty. Finding a safe course between such rocks will always remain the prerogative of the very few. To some extent Pinsky's Inferno, but above all Richard Wilbur's (alas!) only partial translation, show us that a modern 'trasmutazione musaica' of the 'poema sacro' could actually come within reach: a transmutation which does justice to 'tutta sua dolcezza e armonia' and which offers at the same time a worthy and honest interpretation. 



\section{Ciò che potea la lingua nostra. \\ One Hundred and More Years of Dante \\ Translations into Dutch}

PAUL VAN HECK

At the dawn of the twenty-first century, Dante's fortune in the Netherlands is enjoying a very prosperous moment. Within a span of only three years, a remarkably substantial number of Dante versions have seen the light. First and foremost, two new translations of the entire Commedia, published shortly after a new translation of the Inferno, ${ }^{\mathrm{I}}$ integral translations of the Convivio and the De vulgari eloquentia (neither of which was ever before rendered into Dutch), ${ }^{2}$ an anthology of Dante's love poetry, ${ }^{3}$ and reprints of earlier translations of the Vita nuova and the Monarchia. ${ }^{4}$ In addition, a new translation was published of Boccaccio's Vita di Dante. 5 Finally, the world of the Commedia has been brought to life by Dutch artists and musicians. ${ }^{6}$ Never before did the cult of Dante in the Dutch-speaking regions yield such a bountiful harvest in such a short period.

It is not the aim of this contribution to pay to these recent translations and interpretations the critical attention many of them undoubtedly deserve. To some of them, several reflections are dedicated elsewhere in this volume. As may already be clear from its title, the present contribution aims to offer a brief and comprehensive survey of the history of Dante translations into Dutch, from its beginnings until the present day. ${ }^{7}$ Or rather, a survey of the translations of the Commedia, for the translations of the Monarchia and the Vita nuova that have appeared in the course of time will not be treated here. ${ }^{8}$

\section{3-2002: Fifteen Comedies and Three Inferno's}

The first complete translation of the Commedia into Dutch was published on the verge of the sixth centenary of Dante's birth, in I863-64. This date might give rise to the impression of a severe delay, in this respect, of Dutch culture. But such an impression would be at the most only partly justified. It is known, in fact, that the great European Dante revival dates back only to the second half of the eighteenth century, and that translations of the Commedia in the various European languages begin to appear from that time onwards. The first complete translation in German was published in 1767-69, the first in English in 1802, the first in French (after Grangier's, published as early as I596) in I8II-I3. ${ }^{9}$ In the fifty years between the first French translation and the first version in Dutch, the Commedia was rendered into two new languages, Swedish (1856-57) and Polish (I860), which 
implies that Dutch was the sixth modern language in which a complete translation of Dante's masterwork saw the light. ${ }^{\text {IO }}$

Since then, fifteen Dutch translations of the entire Commedia have appeared, to which should be added three renderings of only the Inferno. ${ }^{\text {II }}$ In the following pages, I will present some simple, objective facts and figures, which allow the reader to get a general impression of each of these eighteen translations, and of the men and women who made them. Three tables may suffice to define and to summarize briefly their material appearance, their diffusion, and particularly their content.

In the second column of the first table, the translators' names are given in the precise form in which they appear on the title page of the first edition. ${ }^{12}$ We owe fourteen translations to men, three (the numbers $9,{ }^{13} \mathrm{I} 3$ and $\mathrm{I} 4$ ) to women, and one (no. 17) is the result of a collaboration between a man and a woman. All translators were born and bred in the Netherlands, with the sole exception of the Flemish Dominican friar P.B. Haghebaert, who on the title page of his translation explicitly declares to have translated Dante 'into Flemish'. The linguistic flavor of his version, however, does not essentially differ from that of its northern counterparts of the same period.

The third and fourth columns specify the translated text ( $C$ = Commedia; $I=$ Inferno) and the number of volumes and pages, respectively. ${ }^{\mathrm{I}}$ They show, among other things, that the complete translations of the Commedia were published partially in one volume, partially in three, and in one case in two. ${ }^{15}$

The fifth column gives the size of the publications. The monumental edition of Hacke van Mijnden deserves special mention in this respect: three sumptuous, large folio volumes printed on expensive paper, and containing almost the complete set of engravings by Gustave Doré, ${ }^{16}$ which have become all too common since then, but which at that time were still very novel and considered deliciously original. Rather precious are also the first editions of Bohl (fine paper, spacious typography, gilt edges), Ten Kate (the deluxe edition, with Doré's illustrations), ${ }^{17}$ and Kops (spacious and gracious typography, ample margins). In the case of Hacke van Mijnden and presumably also Bohl, the publication costs were covered by the translators themselves. ${ }^{18}$ In some other cases the editorial outlook is definitely modest: Thoden van Velzen's version is printed on paper of rather poor quality, and Boeken's edition looks fairly simple, too. However, in this last case the elementary outlook is the immediate consequence of an editorial formula, which will be discussed later on.

The sixth column shows the year of first publication, which however is not always explicitly indicated in the books. ${ }^{19}$ From this column, it becomes clear that fertile periods, in which new translations swiftly follow each other, alternate with periods of consolidation, in which only reprints are published. Roughly speaking, four periods of industrious activity can be distinguished. Firstly, the period one could call 'the origins' (the sixties and seventies of the nineteenth century); then, 
the dawn of the twentieth century; thirdly, the period between the two world wars; and finally, the years around 2000.

In the seventh column, the editorial history subsequent to the first edition is summarized by indication of the last known edition. ${ }^{20}$ It becomes clear that approximately half of the translations were never reprinted. Other translations, on the contrary, have been quite successful: this is notably the case for the translations of Boeken, Kops (to which we shall return later on), Bremer, and, in recent times, Van Dooren and Cialona-Verstegen.

As to the amount of printed copies, in some cases it is possible to provide rather exact numbers. Some early translations had a very limited circulation: just 300 copies of Hacke van Mijnden's folio edition were printed; ${ }^{21}$ not many more, probably, were printed of Thoden van Velzen's, and perhaps even less of Loman's Inferno, which was printed and distributed privately. Boeken's translation may be considered the first to attain a truly wide circulation. It is difficult to establish the total amount of copies printed; but some idea might be given by the fact that of the first three (of a total of six) editions of his Inferno translation 5000, 3000 and 3000 copies, respectively, were published..$^{22}$ For a Dutch Dante translation, these numbers were (and still are) quite considerable. This high circulation is explained by the fact that it was published by the 'Maatschappij voor Goede en Goedkoope Lectuur' ['Society for Good and Low-priced Reading'] / the Wereldbibliotheek $\mathrm{NV}$, a socialist-inspired society/publisher which aimed at making quality books affordable to the working class and to readers of modest means. ${ }^{23}$ Therefore, the price was kept deliberately low, and accordingly the editorial format had to remain simple. Some precise figures can also be given for the most recent translations, all of which are still available: of Brouwer's Inferno some rooo copies have been sold up to now, and of his Purgatorio and Paradiso some 600 each; of Janssen's Inferno 4590 , of the Cialona-Verstegen translation some 15,000, and of Van Dooren's even $25,000 .{ }^{24}$ Almost certainly, this last figure has not been surpassed by any other Dutch Dante translation. ${ }^{25}$

\section{Translational Strategies}

The eighth column, finally, shows the literary form of the translation. As everywhere else in the world, in the Dutch-speaking regions very different solutions have been adopted to translate Dante's Commedia. These solutions can be divided conveniently into three groups. The first is formed by the seven translators who chose to cling faithfully to the scheme of Dante's terza rima: strophes of three hendecasyllables tied together by interlocking rhyme. Four of these seven (Hacke van Mijnden, Bohl, Rensburg, Verwey) even opted for absolute fidelity: that is to say, for hendecasyllables with exclusively feminine rhyme. Given the fact, however, that both monosyllabic words and words with accent on the last syllable are much more common in Dutch than they are in Italian, it is perfectly understandable 
that others (Ten Kate, Van Oyen-Zeeman and the duo Cialona-Verstegen) opted for a regular alternation of masculine and feminine rhyme.

A second group of translators (Kok, Kops, Brouwer) renounced Dante's rhyme but not his verse: their versions are, therefore, in blank hendecasyllables. However, between them there are some variations: in Kok and Brouwer one finds an alternation (irregular in the former case, regular in the latter) of masculine and feminine line endings, while in Kops the endings are always feminine. In Kops, moreover, one sometimes notes a certain tendency towards the use of assonance (or consonance) at the end of the lines, in particular between the first and the third line of the tercet. As to the structure of verse lines, whether rhymed or blank, it must be observed, moreover, that differences in execution are manifold. Interpretation and use of diaeresis and sinaeresis, for instance, vary widely, and the same holds true for rhythmical patterns and the use of enjambment.

The translational formulas adopted in the other translations are best qualified by saying what they are not: they are not poetry. Any further division of these versions into subgroups is difficult, because of the gradual rather than essential differences between them. In Van Delft, Bremer and to a lesser extent in Loman, the typographical disposition of the terza rima is maintained, but the number of syllables per line varies somewhere between eight and fifteen, line endings are indifferently masculine or feminine, and the lines themselves are devoid of any regular rhythmical pattern. The segmentation of the text into lines, however, is mostly in harmony with the syntactic structure of the period. For want of a better qualification, this form is defined in the Table as 'between poetry and prose'. Janssen's translation has all of the above-mentioned characteristics, except the last: in his rendering, indeed, one finds nothing that even remotely looks like a search for harmony between line (or strophe) and syntax. This last translation, therefore, could be defined as prose cut into lines of similar length: prose with a poetic mask. In Haghebaert's and Boeken's translations, the only thing that vaguely reminds us of Dante's original poetic form is the segmentation of their plain prose into paragraphs corresponding to the original's tercets. In Frans van Dooren's prose translation, finally, even this last trace of Dante's poetic form has been effaced: his segmentation into paragraphs is just like that of any novel.

In our survey, the translation of U.W. Thoden van Velzen represents an isolated case, for two good reasons. In the first place, it is the only interpretation with a more or less original form, ${ }^{26}$ i.e. a continuous series of hendecasyllables, in which the even lines are tied by masculine rhyme, according to the scheme ABCBDEFEGHIH etc., and the uneven lines, with feminine endings, are left blank. Secondly, Thoden van Velzen shows a rather bewildering approach on the level of content. On the one hand, indeed, the interpreter leaves many passages untranslated, while on the other hand he inserts many passages of his own invention, which explains, among other things, why the number of lines per canto in this translation 
invariably differs from Dante's. ${ }^{27}$ It may be clear that this is a translation hardly worthy of the name.

In order to give at least some idea of this wide range of different approaches, I present in Table 4 all I8 Dutch versions of a famous passage from Inferno 26: the simile of the glowing fireflies that are compared to the myriad of little flames which Dante, standing on the bridge over the pouch of the false counselors, discerns in the dark depths beneath him. [Ill. 4, Inferno 26]

\section{Beyond the Text}

The second and third tables in my survey concentrate on the paratext of the translations. As is well known, this term stands for a whole range of elements that accompany, highlight, comment, recommend in short elements that condition in some way or another a literary text, its fame and its fate. To the paratext belong the foreword, the introduction, the editorial note; the title, the colophon, the indices; extratextual particularities like the typographical characters, the layout, the quality of the paper, the cover, the dust-jacket, and so on; and even the shop price, the publicity that is made for the book, the reviews it receives. The paratext, in short, embraces almost every aspect of a text that lies outside the text itself. An accurate description of the paratext amounts to a description of the way a text presents itself in literary society, and of the welcome it receives.

Tables 2 and 3 present a description of a series of paratextual elements as they appear in the first editions. For this survey, I have focused principally on those elements that were written or chosen by the translator in person, or for which (as in the case of the illustrations) it may be assumed that his preferences were followed or at least taken into consideration. Particularities regarding the cover, the typographical characters, the paper, and so on, as well as the reception by the press, have therefore been left aside.

The third column of Table 2 marks the possible inclusion of the Italian text: it shows that five of the eighteen editions are bilingual. However, with respect to the place where the Italian text is printed, no less than four different solutions are adopted. In Hacke van Mijnden's monumental edition, each page is divided into two columns: the left one contains the Italian text, the other the translation. In Bohl's edition every page is divided into three horizontal sections, the upper containing the translation, the middle the original text, and the bottom section the explanatory notes. In Bremer's and Brouwer's editions, original text and translation are placed on facing pages, on the left and on the right, respectively. In Cialona and Verstegen's two-volume edition, finally, the first volume contains the translation and the illustrations, the second the Italian text and the notes.

The fourth column gives, if there is an explicit indication, the source text on which the translation was based. On this point, however, many translators maintain a complete silence; others generically supply a series of consulted works. 
Only in a few cases is some specific information given. The first translator, Abraham Kok, while omitting to specify the other instruments he made use of, declares to have followed, in case of textual divergences, 'most of the time' the critical edition of Karl Witte, which at the time had just appeared (I862). Van Dooren refers to the annotated edition of Sapegno, which, as he states, 'in its turn is based on Vandelli's. ${ }^{28}$ Janssen mentions the bilingual edition of Singleton, whose Italian text is based on Petrocchi's; and Brouwer's version is based on Petrocchi's text as well.

The opening section of the Dutch editions, where one expects to find some information about the author, his times, his work, and the translation, is mostly succinct and somewhat predictable. In some cases, this opening section is even lacking completely; in many other cases, the so-called introduction would be better termed a preamble or foreword. Oddly, the most ample general introduction is to be found in the oldest translation, albeit in the form of an appendix to its third volume. In Brouwer's translation, one also finds a rather ample introductory section, consisting of a general introduction to Dante and the Commedia by Ronald de Rooy and a survey of Dante's principal classical sources by the translator himself.

However, while the general introduction is mostly succinct and unpretentious, the critical apparatus that accompanies each canto is often more substantial. It mostly consists of a synopsis and of explanatory notes, which, especially in recent editions, tend to become rather numerous and voluminous. The notes are sometimes positioned in the most appropriate place, that is to say at the foot of the page; in other cases they are located at the end of the canto, at the end of the canticle, at the end of the volume, or even (as in the Cialona-Verstegen edition) in a separate volume. Somewhat singular is the solution adopted by Rensburg, whose notes are placed at the beginning of each canto.

Van Delft's edition undoubtedly represents an extreme case. In this edition the notes are not subsidiary to the translation; if anything the translation serves as a kind of prelude to a very ample dissertation on the Commedia: for good reason, indeed, this edition is entitled Dante-Verklaring [Dante Interpretation]. Unfortunately, a complete lack of logical and semantic coherence and of syntactic discipline makes this lengthy interpretation virtually illegible. ${ }^{29}$ Albert Verwey, on the other hand, deliberately renounces every form of explanation: in his edition, one searches vainly for a general introduction worthy of that name, or for an introduction or notes to single cantos. As is generally known, Verwey was a poet himself, and his intention was clearly to emulate Dante rather than to study his work or to make it accessible to the general public. Of all Dutch Commedia versions, Verwey's is undoubtedly one of the most unfaithful or, if one prefers a different expression, one of the most freely translated. ${ }^{30}$ In my survey, both Verwey and Van Delft are isolated cases. 
The last column signals whether the translator presents a comment on the translation as such. Such comments are rather scarce: the only translators who dwell at some length upon their translational work are Van Dooren, who even dedicates a special chapter to it, and, to a somewhat lesser extent, Kops and Janssen. Their colleagues mostly limit themselves to some brief remarks in the foreword or elsewhere, remarks which, especially when written with a clearly apologetic intent, are often rather predictable. In those cases, the translator in terza rima denounces every other approach as a kind of high treason towards Dante's sacred poetry, or at least as highly insufficient and inappropriate, while those who set themselves less ambitious goals tend to stress the utmost impossibility of a faithful translation in the original meter. Similar statements, however, tend to assume the form of a petition of principle: they are almost never solidly argued, nor are they illustrated with appropriate examples.

\section{Dedications, Mottos, Illustrations, and Maps}

In the third table, attention is paid to several other elements of the paratext. Firstly, the dedication, which we find in only three translations: in the two oldest and in Van Dooren's in recent times. Kok's dedication is to no less a person than Queen Sophia, first consort of William III, but it makes its appearance only in the third volume. We may assume, therefore, that the idea of this dedication either came to him at a later stage or that he had to wait for the royal permission for it, which was seemingly indispensable. Hacke van Mijnden dedicates his three majestic volumes to three different persons, including his wife, and Van Dooren's translation is dedicated to his wife as well. In all these cases, the dedication takes the form of a brief nominal sentence. The time that dedications used to assume the form of an elaborate letter or a chapter full of eulogy, gratitude and pleas was already over when our first Dante versions appeared.

Equally rare, in the opening sections, is the introductory motto: it is found only in the first two translations. Kok employs for this the famous interpretative guideline Dante gives in the ninth canto of the Inferno:

$\mathrm{O}$ voi che avete gl'intelletti sani,

Mirate la dottrina che s'asconde

Sotto il velame degli versi strani.

' $\mathrm{O}$ you who have sound understanding, mark the doctrine that is hidden under the veil of the strange verses!' (Singleton)

(Inf. 9, 6I-63)

The same motto (in Dutch) appears in the first volume of Hacke van Mijnden's translation, whose second volume bears as motto Virgil's words 'Gij zult Beatrix zien' ('vedrai Beatrice', Purg. 15, 77). ${ }^{31}$ 
The tradition of including in the opening section of a publication an occasional poem with words of praise for the work or for the author, with warnings and suggestions for the reader, and so on, is nowadays extinguished, but this tradition was still quite alive in the nineteenth century. Such occasional poems are found in Hacke van Mijnden (two even: the first in praise of Dante, the second in praise of the translator), ${ }^{32}$ in Thoden van Velzen, in Ten Kate, and finally, at the beginning of the twentieth century, in Boeken. Subsequently, this element disappears.

Eye-catching components of the paratext are obviously the illustrations. A portrait of Dante is to be found in most editions, including some in which according to our table it should be lacking. In these editions, however, the portrait is placed on the cover, which in the present article is left out of consideration. Most frequently used are Dorés portrait and the famous portrait in the Bargello that is traditionally ascribed to Giotto; but one also finds portraits of other provenance.

If we leave aside the author's portrait, only a minority of the editions is illustrated. Three or four of them (Hacke van Mijnden's, Rensburg's, CialonaVerstegen's, and the luxury edition of Ten Kate) contain the complete or almost complete set of Gustave Dorés engravings. From an illustrative point of view, Janssen's recent edition of the Inferno is undoubtedly the richest and the most original ever published in Dutch. It contains not only many illustrations by Doré, but also a host of (mostly colored) illustrations by other ancient and modern artists, including a series of miniatures from famous manuscripts such as the Dante Urbinate. ${ }^{33}$ Kops's edition deserves special mention, it being the only one that contains illustrations (by Charles Eyk) which were especially made for the occasion.

Many editions contain one or more schematic designs of Dante's afterworld: cross-sections of hell, drawings of the mountain of Purgatory, of the heavens and the empyrean, and so on. Their provenance is almost never indicated.

Finally, some words should be spent on three other possible constituents of the paratext: the errata corrige, the bibliography, and the index of names. The errata corrige is an element of the printed book that with the evolution of the printing process has almost totally disappeared. In our editions, it makes its appearance rather frequently until the thirties of the twentieth century; subsequently, it falls into disuse. It should be noted, moreover, that sometimes (notably in the case of Hacke van Mijnden) the errata corrige is employed not only for correcting printing errors and other minor imperfections, but also for proposing a series of definite and downright textual revisions; in other words, not only for emending, but also for improving the translation.

Only rarely does one find a bibliography in our editions, if at least by this word one means not the occasional mentioning of some titles, but an autonomous, well structured little chapter in which the principal editions of the original text, the principal other translations in Dutch and other languages, some important 
studies and commentaries, and so on are enumerated. A bibliography of this kind is offered only by Van Dooren, Janssen and Brouwer.

A rather essential component of an edition of a lengthy and complex work like the Commedia would seem an index of names and places. However, in earlier times this necessity was obviously seldom felt: almost none of the older editions contains such an index, which becomes a constant and fixed presence only in the recent ones.

\section{The Makers}

The present article does not aim at formulating a detailed qualitative judgment on each of these translations. In order to acquire some plausibility, such judgments should be upheld by ample and adequate evidence, and the present occasion is not that suited to the discussion of such evidence. However, these brief remarks will hopefully suffice to give a certain idea, if not of the merits and demerits of these translations, at least of the foundations upon which they were built and of the success they managed to achieve.

Some words at least, however, should be spent on the people who made these translations. Who were (or are) these translators? What was their place in society? What was their relation with and their attitude towards literature? What drove them to dedicate often years of their life to Dante? The answer to these and other questions is obviously doomed to vary greatly from case to case. But first of all it should be emphasized that one thing they were not: none of our translators was, by vocation or by education, a Dante scholar in the true sense of the word. It was decided by destiny that the Netherlands would never give birth to 'Dantisti' of the stature of a Karl Witte, a Henri Hauvette, an André Pézard, a Karl Vossler, a Hermann Gmelin, a Charles Singleton, just to cite some names of eminent Dante scholars who at a certain (and often late) stage of their lives decided to become Dante translators, too. No Dutch Dante translator ever published a thorough study or even a truly scientific, up-to-date, more or less innovative article on Dante. With one or two exceptions (Janssen and, if one wishes, Verwey), ${ }^{34}$ none of our translators, as far as I know, at least, ever pursued an academic career. At university (if they even went there) they often studied classical literature, theology, Dutch language and literature, and in recent times Italian language and literature. In ordinary life, they were often teachers in secondary schools, protestant ministers, priests, poets, publicists. In the following pages, I will concentrate on those translators whose activities and personalities have long left living memory.

\section{Kok}

The first of them, Abraham Kok (Amsterdam 1831 - Zeist 1915), was trained as a schoolteacher, and from I864 until his retirement in 1896, he taught Dutch and English in various secondary schools (H.B.S.) in Roermond, Tilburg and Breda, 
and at the Royal Military Academy in Breda. Alongside his teaching career, Kok engaged in manifold literary activities. Besides being the first Dutch translator of the Commedia, he was the first to render the complete theatrical works of Shakespeare into Dutch, between ca. 1860 and 1879 . His other publications include translations of Calderón's La vida es sueño (Life is a Dream, I87I) and Byron's Cain (1906), numerous articles on Dutch literature (Vondel, Hooft, Bilderdijk), partly collected in Van dichters en schrijvers. Studiën en schetsen van Nederlandsche Letterkunde [About Poets and Writers. Studies and Sketches on Dutch Literature],35 and also many popularizing contributions on Italian, Spanish and English literature. As a contributor to literary periodicals, he was perhaps the first in the Netherlands to pay attention to Italian literature on a somewhat regular basis: his publications in this field include articles on Dante, ${ }^{36}$ Castiglione, Petrarch, Tasso, Tassoni, Carducci and many others. A few months before his retirement, he was awarded a doctorate honoris causa in Dutch Literature by the University of Utrecht. Notwithstanding his manifold literary interests and occupations, Kok always had a special veneration for Dante. His house in Zeist was called La Vita Nuova, words which after his death were also engraved on his tomb. He owned a precious collection of Dante publications and Dante paraphernalia, which unfortunately seems to have fallen apart. ${ }^{37}$

\section{Hacke van Mijnden}

The second translator, Jan Conrad Hacke van Mijnden (Haarlem I8I4 - Loosdrecht 1873), was the son of a protestant minister of German origin, Conrad Hacke. He studied classical literature at the University of Utrecht, where in 1840 he took his $\mathrm{PhD}$ with a thesis on Bessarion, entitled Disputatio literaria inauguralis, qua Bessarionis aetas, vita, merita, scripta exponuntur. Being a man of ample means, he never had the need nor (it seems) the desire to procure himself a stable occupation, living the life of a studious gentleman between countryside (Loosdrecht) and city (Amsterdam), while occasionally spending the winter in Italy. He started to work in earnest on his Dante translation, the idea of which he might have cherished as early as I840, in I862-63. The years he dedicated to Dante brought him great satisfaction, but also deep personal grief. Shortly after having finished his version of the Inferno (1865), the feared throat disease took away four of his children within a couple of weeks; a few years later, he lost his wife. Hacke van Mijnden himself did not live to see his translation of the Paradiso in print, which was published some months after his death. ${ }^{38}$

\section{Thoden van Velzen}

The third translator, Ubbo Wilhelm Thoden van Velzen (Oudkerk I8I5 - I892), was born into a Frisian family of ministers. He studied theology (probably in Groningen) and subsequently became a minister himself: from I852 until his 
death, he served the parish of Bergum-Bergumerheide. All his (mostly religious) publications had a very limited circulation and are not always easily distinguishable from those by his near namesake Ulphart Willem Thoden van Velzen. He also published some poetry, some occasional writings (among which a report of a voyage through the Alps) and a short portrait of Dante, whom he regarded as a precursor of the Reformation (Dante als dichter, wijggeer en christen [Dante as a Poet, a Philosopher and a Christian], ca. 1856). ${ }^{39}$

\section{Ten Kate}

The fourth translator, Jan Jacob Lodewijk ten Kate (Den Haag I819 - Amsterdam I889), studied theology at the University of Utrecht and subsequently served as a minister in Marken, Almkerk, Middelburg and finally Amsterdam. However, he acquired renown especially as a poet: during his life, he produced a nearly endless stream of religious, dramatic, didactic and naturalistic poetry, thus becoming one of the most typical representatives of the figure of the minister-poet, once such a dominant presence in Dutch literature. Besides poetry, he published much didactic and narrative prose and a host of occasional writings. Of his many poetic translations and adaptations, only that of Tasso's Gerusalemme liberata (1856) is worth mentioning in this context. ${ }^{\circ}$

Ten Kate's version of the Inferno was published in 1876; but his interest in translating Dante dates back to an early stage of his literary career. In 1846 , he published a version of the first canto of the Inferno $;{ }^{4 \mathrm{I}}$ in $\mathrm{I} 847$, he finished a version of the first ten cantos. ${ }^{42} \mathrm{Had}$ he continued, he would have easily become the first translator of the Commedia into Dutch; but subsequently, his attention was diverted by other literary projects. He returned to Dante only in the I87os, presumably after the death of his friend Hacke van Mijnden, whose translation he had at least partly read and commented upon before its publication. ${ }^{43}$ If we may believe Ten Kate's introduction to his own edition, the reason he decided to complete and publish his translation of the first canticle was essentially the very limited circulation of Hacke van Mijnden's edition. ${ }^{44}$

What distinguished Ten Kate from most other Dante interpreters was his considerable literary fame, which enabled him to ably commercialize the products of his pen. Notwithstanding the substantial printing costs of the luxury edition of his Inferno, he demanded and managed to obtain from his reluctant publisher the sum of 1500 guilders for his translation work. ${ }^{45}$

\section{Bohl}

Ten Kate's version appeared almost simultaneously with the Inferno translation of Joan Bohl (Zierikzee I836 - Amsterdam I908), who did not hesitate to launch a rather caustic attack on his rival. ${ }^{46}$ After his study of law, Bohl established himself as a lawyer in Amsterdam. In I865, he took his doctoral degree in Leiden with 
a thesis on Een tweetal vragen van Nederlandsch regt [Two Questions Concerning Dutch Law]. His other publications include a lengthy study on De godsdienst uit staat- en rechtskundig oogpunt [Religion Considered From a Political and Juridical Point of View, I871], which also appeared in German, a number of juridical and political-juridical writings, of which at least a French translation of the Italian Commercial Code (Code de Commerce du Royaume d'Italie, I884) should be mentioned, and furthermore some poetry, some narrative prose, some autobiographical notes, some historical sketches, and other occasional writings. His Dante versions appeared both as autonomous publications and as issues of "De Wachter: Nederlands Dante-orgaan» ["The Guardian. A Dutch periodical on Dante»], a personal creation of Bohl, of which he remained the only editor.

\section{Rensburg}

Bohl's translation was followed at the dawn of the new century by that of the Dominican friar P.B. Haghebaert, about whom little is known to me, ${ }^{47}$ and subsequently by a version from Jacques Karel Rensburg (Den Haag 1870 - Sobibor 1943). A rather eccentric, bohemian-like personality, Rensburg was full of ideas about astral naturalism and messianism, to which he occasionally gave some literary expression. He tried to earn himself an honest living by translating or adapting other people's translations, but he lived for most of his life in indigence. Of all our interpreters, he might be the only one whose translation was more or less commissioned. His love for the Poet, though, is beyond doubt: in his introduction, he tells us that from the age of eighteen, his literary activities and his thinking were largely dominated by Dante. Although we cannot be sure that he knew enough Italian to read the Commedia in the original, he set himself a very high aim: to make a translation in the exact meter of the original, with ample explanatory notes. Unfortunately, his Dante version, just like that of the Decameron which shortly preceded it (1905), was doomed to become much less than modest. ${ }^{8}$

\section{Boeken}

Before Rensburg had completed his translation, another one was already being published by Hein Boeken (Amsterdam I86I - Amsterdam 1933), a classicist, translator and poet, who today is perhaps best known as the lifelong friend of one of the most innovative literary personalities of the late nineteenth century: Willem Kloos. ${ }^{49}$ Though a poet himself, Boeken decided to translate the Commedia in prose. Thanks to the wide circulation it attained, his version must have played a rather substantial role in the circulation of the Commedia in the Netherlands. To the attentive reader, however, this all too literal and therefore somewhat obscure version leaves a rather obligatory impression. Boeken clearly did not feel for Dante the genuine enthusiasm and the sincere devotion that are so easily discernable in the work of many of his colleagues. 


\section{The Special Case of Christinus Kops}

About Van Delft and Verwey, who published their translations in the years around Dante's anniversary, something has already been said. Much more interesting than theirs is the version by Christinus Kops, which was initially published in the same period. In this version, indeed, a sincere effort to understand the letter of Dante's words and the purport of his thought goes hand in hand with a translational ability that came to be quite remarkable. Certainly, Kops's version is not faultless, as he himself was the first to realize. Nevertheless, of all the interpretations published in bygone times, this is perhaps the only one that after so many years can still be read with approval; perhaps the only one, too, that still is capable of stirring up genuine emotions in the reader.

Christinus Kops (Haarlem I876 - Megen 195I) joined the Franciscan order at the age of eighteen and was ordained as a priest in 190I. He was trained in the Dutch language and literature, subjects he taught for most of his working life at the Franciscan seminaries in Megen and Venray. His interest in Dante must have arisen rather early. In the years 1907-I9Io he published a series of introductory articles to the three canticles of the Commedia in the periodical «Van onzen tijd». In I9I7 he published in "Tijdschrift voor Taal en Letterkunde» a short contribution on De beeldspraak in Dante's Goddelijke Komedie [Imagery in Dante's Divine Comedy], which was followed in I92I by a very critical review of Van Delft's Dante interpretation in the same journal.

Kops's own Dante translation was published in different stages. Between December 1922 and June 1925 he published a version of the Inferno in «Roeping». Subsequently, a translation of the entire Commedia was published first - from the second half of 1927 - in monthly issues and afterwards in three volumes (19291930). Though the translation as such was well received, this neatly printed edition did not become a resounding editorial success: not only was it never reprinted, in the course of the I930s the price of the remaining stock was also reduced to about one-third. ${ }^{\circ}$

As time went by, however, Kops became more and more unsatisfied with his interpretation, and eventually he decided to restart more or less from scratch. Towards the end of 1943 , the work was virtually finished: contacts with a publisher had been established, and an illustrator had already been engaged. However, due to causes that remain somewhat unclear, ${ }^{5 \mathrm{I}}$ during Kops's lifetime this new translation was never to see the light of day. In 1957, six years after his death, a favorable moment seemed to dawn. In that year the Antwerp publisher Pelckmans decided to republish Kops's translation, as a successor to Haghebaert's which he had reissued ten years earlier. Being informed, however, of the existence of the new version and not knowing which of the two to choose, he entrusted the editing of the new edition to Gerard Wijdeveld (1905-97), in that time a literator of some renown in Catholic circles. Wijdeveld judged the new version inferior to the published one, 
but this unfavorable judgment did not prevent him from using it whenever he thought this appropriate. Whenever a line, a locution, a word of the new version seemed to him preferable to the corresponding element in the original, he simply replaced it. In addition, he adapted the spelling to the accepted rules of his time, ${ }^{52}$ reduced the apparatus of the notes to about a third or a fourth of its original size, knocked together a short introductory note which by his own admission was largely copied from Haghebaert's introduction, and added a paragraph in which he gave an account of his editing procedure. ${ }^{33}$ In this hybrid form, Kops's translation was republished in 1957, and since then it has enjoyed a success unknown by the original edition. In 1999, the eleventh printing was issued which is still available today. 54

The only way to get an exact idea of the differences between the first and the second version would be, of course, to compare them with the manuscript of the latter. However, unfortunately, my repeated efforts to trace this manuscript have hitherto remained fruitless. 55 Some time ago, however, I was happy to find an important witness to the genesis of the new version, Father C.P. Voorvelt, a Franciscan of venerable age. ${ }^{56}$ In his younger years, Father Voorvelt not only knew Father Kops quite well, but he also assisted him assiduously in preparing his new translation. ${ }^{57}$ Thanks to Father Voorvelt, I have come into possession of copies of letters by Kops to him, which give a certain impression of their collaboration and of Kops's efforts to get his new version published. They also tell us something about his working method. In March I943, for instance, he writes, 'I mostly read the verses aloud: it is the best way to check if they run well, sound well, etc.' As may be concluded from another letter he wrote that same month, the final result didn't displease him: 'I must say that now that it [the Inferno] lies in typoscript before me, I rather like it. The language seems quite simple, natural and yet melodious to me.'

Kops's Dante translation was by far the most important literary achievement in the life of an industrious, ${ }^{58}$ profoundly Catholic,, 99 yet rather open-minded ${ }^{60}$ personality. Between the beginning and the conclusion of its long creational process lie at least twenty and perhaps even more years. A concrete illustration of this process is provided by Table 5, containing the translation of the first nine tercets of the Inferno as they appeared in «Roeping», in the first edition in volume, and in Wijdeveld's edition. The numerous italicized text parts in the first and second version indicate the modifications in the second and the third, respectively. ${ }^{61}$ Apart from being numerous, the corrections often appear quite judicious. Though the present occasion is not suited for a detailed analysis, it seems justified to conclude that over the years the translation clearly gained in precision, in agility, in modernity, in naturalness.

The divergences between the first two versions registered in the Table faithfully reflect the discrepancies between these two versions as a whole: the second, 
in fact, is largely new with respect to the first. The overall differences between the second and the third version, however, are not as great as might appear from the fragment in the Table. In Wijdeveld's edition, thoroughly revised passages alternate with long stretches of text in which there are very few corrections. However, it is of course impossible to tell whether the corrections are scarce because Kops hardly made any or because Wijdeveld did not copy them from the manuscript into the text. Judging from Wijdeveld's introduction, the second hypothesis seems more plausible than the first. ${ }^{62}$

\section{From Bremer to Brouwer}

Kops's translation was followed by two versions made by women: Betsy van OyenZeeman, ${ }^{63}$ whose translation seems to have left no vestige whatsoever in the literary landscape, and Frederica Bremer, ${ }^{64}$ whose translation was made without any artistic aspirations and with the sole objective of rendering Dante's masterwork accessible and understandable to a general public. Bremer's translation would become the most read (and for many years the only available) in the middle part of the century.

After Bremer's version, almost half a century would pass before new translations were published: first, in 1987, the prose translation by Van Dooren, ${ }^{65}$ then, twelve years later, Janssen's Inferno (1999), ${ }^{66}$ and the integral translations by CialonaVerstegen in terza rima $(2000)^{67}$ and by Brouwer in blank hendecasyllables (2000-2002). ${ }^{68}$

Divided by their translational formulas, united in their efforts to make the Commedia accessible to the modern reader by means of a wealth of annotations, together these last translations form a landmark with which any future Dutch translator will necessarily have to compete. But is there, after all the work that has been done, still something left to desire? Well, perhaps. Perhaps, after so many translations in terza rima, in blank hendecasyllables and in plain prose, the time has come to break new ground and try to render the Commedia in truly rhythmical, poetical prose: to make a translation which, while offering the semantic precision that only a version in prose can hope to guarantee, offers at the same time a rhythmical animation and a poetical fascination not wholly unworthy of the original. No Dutchman ever tried; maybe someday somebody will feel prepared to take up the gauntlet. 

Tables

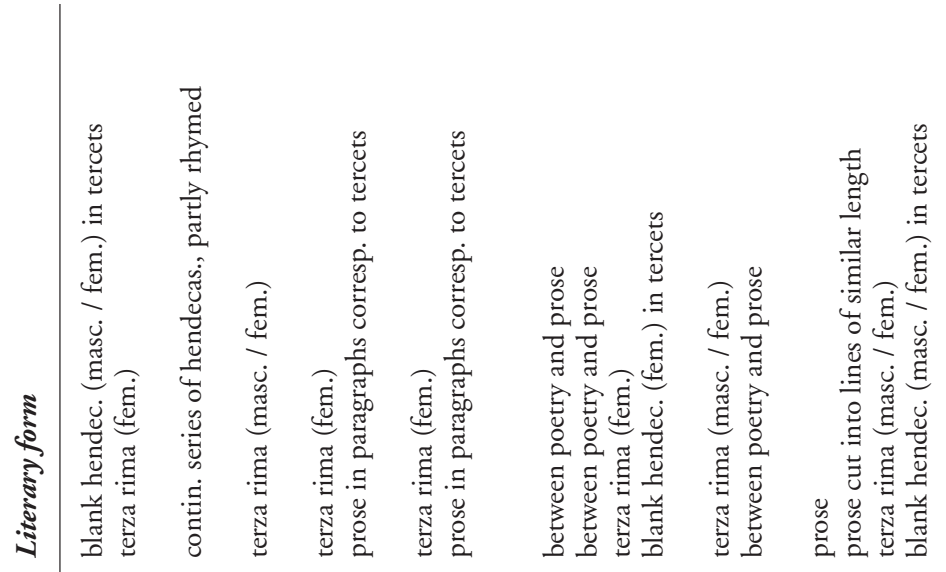

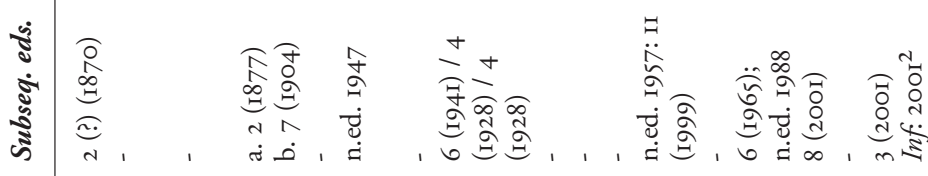

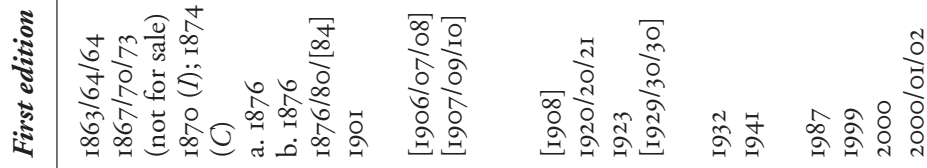

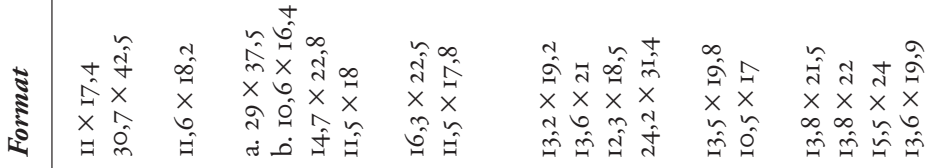

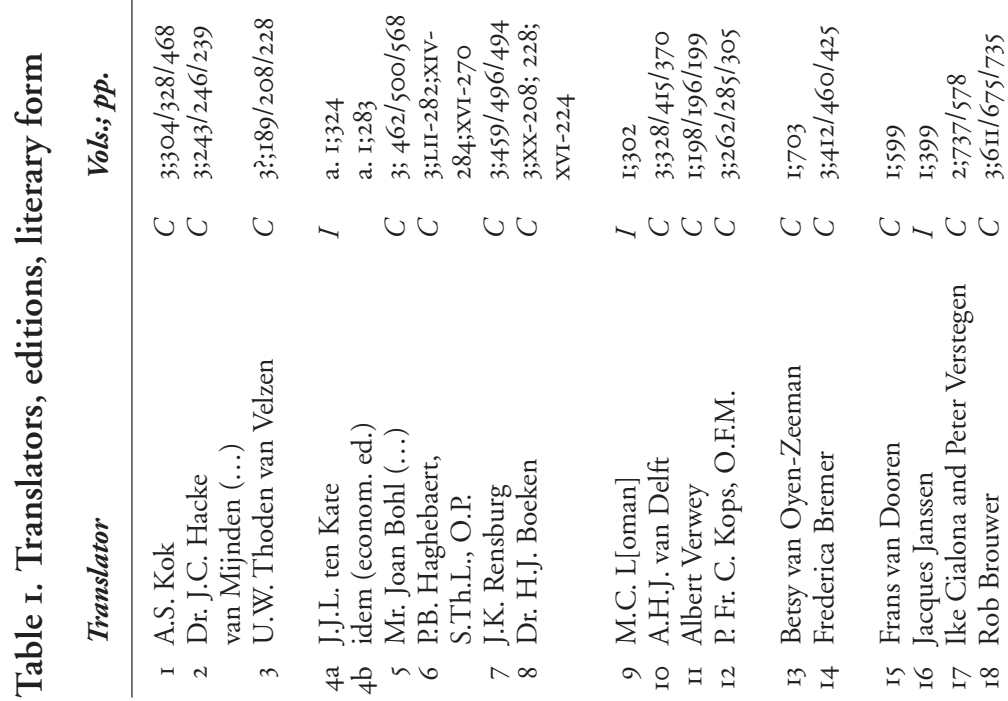




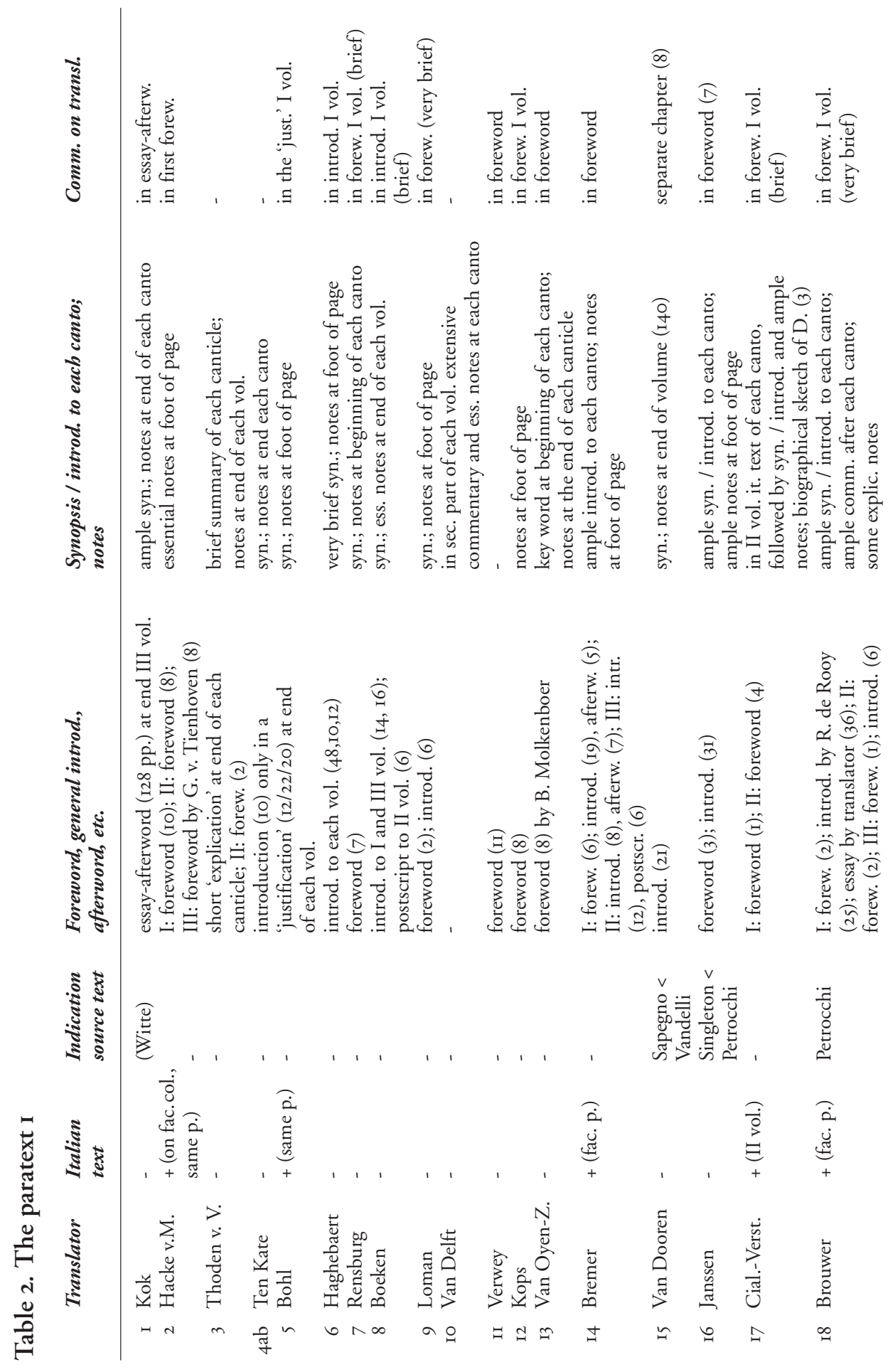




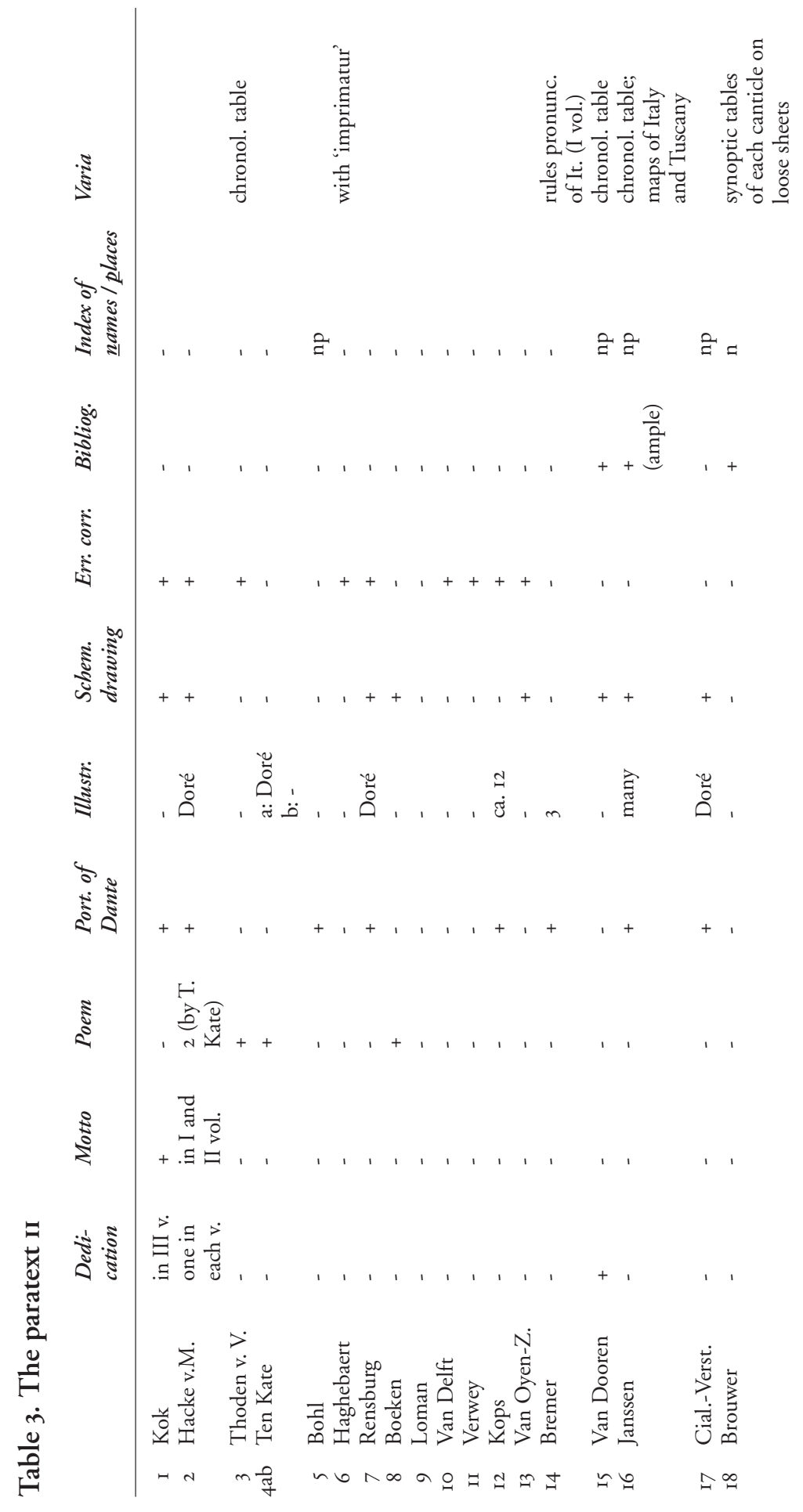


Table 4. Translations of Inf. 26, 25-33

\section{Dante (ed. Chiavacci Leonardi)}

Quante 'l villan ch'al poggio si riposa, nel tempo che colui che 'l mondo schiara la faccia sua a noi tien meno ascosa,

come la mosca cede alla zanzara, vede lucciole giù per la vallea, forse colà dov'e' vendemmia e ara:

di tante fiamme tutta risplendea l'ottava bolgia, sì com'io m'accorsi tosto che fui là 've 'l fondo parea.

\section{Kok (I863)}

Gelijk de landman, rustende aan een heuvel In 't jaargetij, als zij die de aard verlicht

Haar aangezicht het kortst voor ons verbergt,

En wel, wanneer de mug de vlieg vervangt, In 't dal de glimworm flikkren ziet bij duizenden, Waar hij den wijn oogst of de ploeg hanteert:

Van zooveel vlammen vuurs weêrblonk in 't rond Heel de achtste balg, gelijk ik kon bemerken, Zoodra ik was waar zich de bodem voordoet.

\section{Hacke van Mijnden (1867)}

De landman, aan een heuvel neêrgelegen, In zomertijd, wanneer de zon haar stralen Het langst ter neêr laat vallen op de wegen,

Wanneer de mug de vlieg vervangt der dalen, Ziet dan den glimworm schittren in het ronde, En glinstrend over 't rijpe graanveld dwalen:

Zóó zag ik vlammen flikkren op deez’ stonde, Zoodra wij de achtste groeve voor ons zagen, En ' $\mathrm{k}$ in de diepte nederstaren konde.

\section{Thoden van Velzen (1874)}

(...) De landman aan den heuvel

Zich nedervleijend in het avonduur,

Wanneer de zon haar laatste stralen neerzendt In gouden glans tot koestering der natuur, Als muggen reeds de plaats der vlieg vervangen, Ziet zoo veel duizende glimwormen niet In 't dal, alwaar hij ploegt, of wijn bouwt, lichten, Als ik hier zag beneden in 't verschiet.

Dien achtsten Balg zag ik van vlammen schittren, Alom, zoodra ik kwam ter plaats, alwaar Ik zien kon op den grond. (...)

\section{Ten Kate (1876)}

In 't zomertij', als zij wier stralenregen Onze aard verlicht, voor kort maar ònder ging, Als 't vliegjen wijkt, de muggen zich bewegen:

Ziet vaak de landman van den heuvelkling In 't wijndal, of op de omgeploegde gronden Der glintwormlichtjens verre flikkering:

Dus, als wij voor die Achtste Groeve stonden, Ontdekte ik duizend vlammen in het rond, Zoodra wij in de diepte blikken konden.

\section{Bohl (1876)}

Ten tijd, dat zij, die de aarde licht komt geven, 't Gelaat ons 't minst verbergt; de vlieg moet wijken Voor 't muggenheir, zit vaak, tot rust gedreven

Op 's heuvels top, de boer naar 't dal te kijken, En ziet het lichtwormpje in 't ontelbre pralen, Soms waar hij wijn oogstte of den ploeg liet strijken;

Zóóvele vlammen zag 'k hier vurig stralen In de achtste spleet; naar ' $k$ waarnam in die sferen, Zoodra ik in haar afgrond neêr kon dalen. 


\section{Dante}

Quante 'l villan ch'al poggio si riposa, nel tempo che colui che 'I mondo schiara la faccia sua a noi tien meno ascosa,

come la mosca cede alla zanzara, vede lucciole giù per la vallea,

forse colà dov'è vendemmia e ara:

di tante fiamme tutta risplendea

l'ottava bolgia, sì comio m'accorsi tosto che fui là 've 'l fondo parea.

\section{Haghebaert (I9OI)}

In het jaargetijde dat de ster, waardoor 't heelal verlicht wordt, haar gezicht ons minst verborgen houdt, dan ziet de landman rustend op de heuvel,

Als de vliegen voor de muggen wijken, in het dal, waar hij zijn 'wijngaard en zijn' akker heeft, bij duizend lichtjes zweven;

Zoo glansden in die achtste kloof ook vlammen, gelijk ik kon bemerken, als ik op de plaats gekomen was, waar men den grond kon zien.

\section{Boeken (1907)}

Zoovele lichtjes als de daglooner, die tegen de helling uitrust, in den tijd dat degene, die de wereld verlicht, zijn aangezicht korter voor ons verborgen houdt,

ziet (op het uur) wanneer de vlieg wijkt voor de mug: zoovele lichtjes als hij dan ziet onder (zich) in de vallei, wellicht daar waar hij (des daags) in de wijngaard werkt of ploegt;

van zoovele lichtjes weerschitterde de gansche Achtste Buidel, zooals ik bemerkte zoodra ik daar was, waar diens bodem zichtbaar werd.

\section{Loman (1908)}

Zooals de boer, die op de hoogte uitrust ten tijde dat zij die de aarde verlicht haar aangezicht langer naar ons toekeert;

als de mug de vlieg opvolgt, en hij de lichtkevers ziet zweven in het dal, misschien wel daar waar hij oogstte en eerst ploegde;

zoo was door de vlammen alles verlicht in den achtsten balg; dit werd ik gewaar zoodra de afgrond zich aan mij vertoonde.

\section{Rensburg (1906)}

Gelijk de boer rust aan den kling gezonken Ten tijde, dat hij, die 't licht schenkt aan d'aarde, Het aanschijn op zijn langst voor ons doet pronken,

Gelijk de mug dan na de vlieg rondwaarde En hij ziet, hoe glimwormen 't dal doortogen Licht waar hij ploegde' of den wijnoogst gaarde,

Zag 'k heel den achtsten Balg door glans bevlogen Van vlammen even talrijk, als 'k kon merken, Zoodra ' $k$ den bodem peilde met de oogen. 
Dante

\author{
Quante 'l villan ch'al poggio si riposa, \\ nel tempo che colui che 'I mondo schiara \\ la faccia sua a noi tien meno ascosa, \\ come la mosca cede alla zanzara, \\ vede lucciole giù per la vallea, \\ forse colà dov'e' vendemmia e ara: \\ di tante fiamme tutta risplendea \\ l'ottava bolgia, sì comiio maccorsi \\ tosto che fui là 've 'l fondo parea.
}

\section{Io. Van Delft (1920)}

Zoovele lichtkevertjes als de landman, rustend aan den heuvelkling

in 't uur, dat zij, die de aarde belicht, het minst voor ons haar aanschijn verschuilt

En dat de vlieg wijkt voor den kever; zoovele hij er dan ziet benee in 't dal, waar hij allicht in den wingerd plukt en ploegt;

Van zoovele vlammen blakerde overal de achtste balg, gelijk ik dadelijk bemerkte, als ik kwam op 'n plek, waar ik den bodem kon zien.

\section{Verwey (1923)}

Zoovele als in 't seizoen wanneer de naven Van 't zonnevoertuig langste baan berijden, Ter helling rustend na zijn lange slaven

De landman lichtjes door het dal ziet glijden Op 't uur dat vliegen wijken, muggen dansen, En denkt aan 't werk in wijngaard of op weiden,

Zoovele lichtjes zag ik ginder glanzen In de achtste buidel, toen wij nederkeken Waar onze rotsen zijn terrein omschansen.
I2. Kops (1929)

Gelijk de landman rustende op de heuvel - ten tijde, dat het grote licht der wereld z'n aangezicht ons korter houdt verborgen -

zohaast de vliegjes wijken voor de muggen, wel duizend lichtjes in het dal ziet flikkren, waar hij misschien z'n wijngaard heeft of akker:

van zoveel vuren lichtte aan alle zijden het achtste diep, als ook m'n oog bespeurde, zohaast ik stond, waar't dal z'n bodem toonde.

\section{Van Oyen-Zeeman (1932)}

Zooals de boer - die uitrust op de bergen, In 't jaargetij, dat zij, die de aard' verlicht, haar aangezicht het minste zal verbergen,

als voor de muggen 't vliegenleger zwicht glimwurmpjes ziet, die in het dal ronddwalen, dat hij bebouwt en waar hij oogst wellicht,

zoo zenden tal van vlammen hunne stralen door de achtste spleet, zooals ik heb ontwaard, nu wij geheel tot op den bodem dalen.

\section{I4. Bremer (I94I)}

Zooveel als de landman, die rust op den heuvel, In den tijd, dat hij die de wereld verlicht Zijn gelaat voor ons het minst houdt verborgen,

Op den tijd dat de vlieg haar plaats ruimt voor de mug, Vuurvliegen ziet beneden in het dal Misschien daar waar hij den wijn oogst of ploegt:

Van zooveel vlammen schitterde geheel De achtste klooof, gelijk ik gewaar werd, Zoodra ik daar was waar de bodem gezien werd. 


\section{Dante}

Quante 'l villan ch'al poggio si riposa, nel tempo che colui che 'I mondo schiara la faccia sua a noi tien meno ascosa,

come la mosca cede alla zanzara, vede lucciole giù per la vallea, forse colà dov'è vendemmia e ara:

di tante fiamme tutta risplendea l'ottava bolgia, sì comio m'accorsi tosto che fui là 've 'l fondo parea.

\section{Van Dooren (1987)}

Zoveel vuurvliegjes als de landman 's zomers (wanneer de zon haar gezicht het minst voor ons verbergt) op het tijdstip dat de vliegen voor de muggen wijken, vanaf de heuvel waar hij zit uit te rusten beneden in het dal ziet glinsteren, en misschien zelfs op de plaats waar hij oogst en ploegt, zoveel vlammen lichtten er op uit de achtste ringgracht die voor ons lag: dat werd ik gewaar toen ik het punt bereikte vanwaar ik de hele bedding kon overzien.

\section{I6. Janssen (1999)}

In het seizoen waarin de zon haar lichtend gelaat het minst vaak voor ons verbergt, en op het uur waarop de vliegen voor de muggen wijken, ziet

de boer die uitrust op de heuvel vuurvliegjes zweven beneden in het dal, misschien wel daar waar hij zijn wijngaard en zijn akker heeft.

Welnu, evenveel vlammen kon ik zien opgloeien in de achtste zak zodra ik de hele bedding overzag.

\section{I7. Cialona-Verstegen (2000)}

Zoals de boer die op een heuveltop Pauzeert om rustig in het rond te kijken, 't Is zomer en de zon schijnt nog volop-

Die, als de vliegen voor de muggen wijken, Vuurvliegjes ziet beneden in het dal,

Tot waar, langs druif en aar, zijn ogen reiken,

Zo kon ik vele vuren overal

In deze achtste klove observeren,

Toen ik omlaag keek: vlammen zonder tal.

\section{I8. Brouwer (2000)}

Vaak ziet een boer die rust neemt op een heuvel - in 't jaargetij als 's werelds licht voor ons de kortste tijd zijn helle aanschijn schuil houdt -

wanneer de vlieg het veld ruimt voor de mug, geglim van lichtjes in het dal beneden, misschien daarginds waar hij vaak oogst of ploegt:

net eender lichtten in de achtste buidel de vlammen op; ik nam ze waar zodra ik mij bevond vanwaar ik 't diepste zien kon. 


\section{Table 5. The beginning of the Inferno in three versions by Christinus Kops}

\section{Dante (ed. Chiavacci Leonardi)}

Nel mezzo del cammin di nostra vita mi ritrovai per una selva oscura, che la diritta via era smarrita.

Ahi quanto a dir qual era è cosa dura esta selva selvaggia e aspra e forte che nel pensier rinova la paura!

Tantè amara che poco è più morte; ma per trattar del ben ch'i' vi trovai, dirò de l'altre cose ch'i' v'ho scorte.

Io non so ben ridir com'i' v'intrai, tantera pien di sonno a quel punto che la verace via abbandonai.

Ma poi ch'i' fui al piè d'un colle giunto, là dove terminava quella valle che mavea di paura il cor compunto,

guardai in alto e vidi le sue spalle vestite già de' raggi del pianeta che mena dritto altrui per ogne calle.

Allor fu la paura un poco queta, che nel lago del cor mera durata la notte ch'i passai con tanta pieta.

E come quei che con lena affannata, uscito fuor del pelago a la riva, si volge a l'acqua perigliosa e guata,

così l'animo mio, ch'ancor fuggiva, si volse a retro a rimirar lo passo che non lasciò già mai persona viva.

\section{version published in «Roeping» (1922)}

Juist midden op de weg van 't menslik leven was ' $k$ in ' $n$ sombre woudvallei aan 't dolen, daar ik de goede richting had verloren.

Helaas, hoe 't was dat woud, valt zwaar te zeggen. Zo wild en woest was het, zo dicht en donker, dat ' $k$ in mijn hart nog d'angsten voel herleven.

En zelfs de dood kan haast niet erger wezen. Maar om van 't daar gevonden heil te spreken zal 'k ook verhalen wat ik eerst aanschouwde.

Hoe ik er binnenkwam, kan 'k niet meer zeggen; zo zeer had slaap min zinnen overmeesterd, toen ik van 't rechte pad was afgeweken.

Maar toen ' $k$ de voet eens heuvels was genaderd, daar waar de donkre woud-vallei 'n eind nam, die mij van vrees zo hevig had doen siddren,

blikte ik omhoog en zag des heuvels schouders reeds met de stralen dier Planeet omhangen, die iedereen de ware weg doet kennen.

Toen werd de vrees allengs 'n weinig stiller, die door mijn diepste hartebloed gewoeld had geheel die nacht, waarin ' $k$ zo veel verduurde.

Zoals ' $n$ mens met uitgeputten adem de zee ontworsteld en aan 't strand gekomen, nog eenmaal omziet naar het wilde water,

zo keerde zich m'n geest, nog altijd vluchtend, nog eens naar wat hij achter had gelaten, en wat geen mens ooit levend liet ontkomen. 
version published in $1927-29$

Juist midden op de reistocht van ons leven zag ik mij in ' $n$ donker woud verloren, daar ik van 't goede pad was afgeweken.

Helaas, hoe 't was dat woud, valt zwaar te zeggen. Zo wild was 't en zo woest, zo dicht en donker, dat in mijn dromen de angsten vaak herleven.

Ja, zelfs de dood kan haast niet erger wezen. Maar om van 't daar gevonden heil te spreken, zal 'k ook verhalen, wat ik eerst aanschouwde.

Ik weet niet meer, hoe ik er binnendoolde; zo had de slaap mij in dat uur vermeesterd, toen ik de ware weg de rug toekeerde.

Maar bij de voet eens heuvels aangekomen, daar waar het uiterste einde was der delling die mij van angst het hart had saamgewrongen,

blikte ik omhoog en zag des heuvels schouders reeds met de stralen dier Planeet ombangen, die ieder veilig leidt langs alle wegen.

Toen werd de vrees toch wel ' $n$ weinig stiller, die eerst gewoed had op de zee mijns harten de nacht, die ik doorwaakte in zulk 'n lijden.

En evenals de man, die buiten adem vanuit de diepe zee aan land geworsteld, zich omkeert en dan tuurt naar 't wilde water,

zo keerde zich mijn geest, die steeds nog vluchtte, weer achterwaarts, om naar het woud te staren, waaruit geen ziel ooit levend wist te ontkomen. version ed. by Wijdeveld (5 ${ }^{\text {th }}$ ed., 1982)

Juist midden op de reistocht van ons leven zag ik mij in een donker woud verloren, daar ik van 't goede pad was afgeweken.

Helaas, hoe 't was, dat woud, valt zwaar te zeggen: zó wild was 't en zó woest, zó dicht en donker, dat de angsten nog herleven bij 't herdenken.

Ja, zelfs de dood kan haast niet erger wezen. Maar om van 't heil dat ik daar vond te spreken zal 'k ook verhalen, wat ik eerst aanschouwde.

Vaag heugt mij maar, hoe ik er binnendoolde: zó had de slaap mij in dat uur vermeesterd, toen ik de ware weg de rug toekeerde.

Maar toen ik bij een heuvel was gekomen, daar waar de grenzen liepen van de delling, die mij van vrees het hart reeds had doorstoken,

keek ik omhoog en zag zijn kruin omgeven door 't licht van de planeet, die met zijn stralen ons allen veilig leidt langs alle wegen.

Toen werd de vrees toch wel een weinig stiller, die eerst gewoed had op de zee mijns harten, geheel die nacht dat ik zo veel verduurde.

En evenals de man die, buiten adem vanuit de diepe zee aan land geworsteld, zich omkeert en dan tuurt naar 't wilde water,

zo keerde zich mijn geest, die steeds nog vluchtte, weer achterwaarts om naar het woud te staren, waaruit geen mens ooit levend was ontkomen. 



\section{Translating Dante's Translations}

PIETER DE MEIJER

Up to the last years of the twentieth century, a fairly large number of Dutch translations of the Divina Commedia had already been published. However, the years of transition towards the twenty-first century have seen an astonishing number of new translations of (parts of) Dante's magnum opus. In some cases the translation is accompanied by a remarkable apparatus of notes, comments, and illustrations. In 1999 Jacques Janssen published Mijn Komedie: Hel; ${ }^{\mathrm{I}}$ in 2000 Ike Cialona and Peter Verstegen published their De goddelijke komedie; ${ }^{2}$ in 2000 Rob Brouwer published the first volume (Inferno) of his translation De Goddelijke Komedie, to be followed in 200 i by the second volume (Purgatorio) and in 2002 by the third (Paradiso). ${ }^{3}$ This exceptional phenomenon can only be compared to the recent flourishing of English Dante translations in the USA, if the scale of diffusion of the two languages would not make such a comparison rather trivial.

The recent outburst of Dutch Dante translations is clearly not an isolated phenomenon of some translators wanting to take up the challenge of a very difficult task. The mentioned translations are part of a more general interest in Dante. In the same short period translations of other works by Dante were also published, such as his Convivio (200I) ${ }^{4}$ and the De vulgari eloquentia (200I), 5 but also a study on Dante by Wiel Logister (2000), ${ }^{6}$ a translation of Boccaccio's Vita di Dante by Ike Cialona (2002), ${ }^{7}$ and such a superb booklet as Toon Tellegen's Enkele Onwaarschijnlijke Aantekeningen van Dante Alighieri bij het Schrijven van zijn Goddelijke Komedie (200o) [Some Unlikely Notes by Dante Alighieri While Writing His Divine Comedy]. ${ }^{8}$

To explain Dante's success in the Dutch culture at the end of the twentieth century and the beginning of the twenty-first, we should not limit ourselves to the motivations of translators, scholars, and writers. We should also take into consideration the fact that Dutch readers, at least in the estimates of the publishing houses, are willing to make the effort to read, interpret, and appreciate a literary work that requires more than the usual amount of attention, even when translated. The readers' motivation could be of even greater interest than the translators'; in fact, perhaps the readers' motivation could tell us something important about our present-day living conditions. At the risk of presenting a highly hypothetical explanation, I would say that the current interest of the Dutch in Dante's work might be explained as the interest in a literary work whose aesthetical and ethical values represent the opposite of our own Dutch world. We are living in a society that wants to free itself from any aesthetical and ethical rigidity, that refuses any 
transcendental point of view, and that speaks of standards and values mostly as objects of research. In this kind of society, the Divine Comedy's formal and ethical rigor, together with its radically transcendental viewpoint, represent an alternative which can be considered with stupefaction and perhaps even with some nostalgia.

I will not explore this question any further, and I will limit myself to the translators' concrete motivations and to their formal choices in translating Dante's poetry. I will do so by concentrating on a specific aspect of the Divine Comedy, which represents a particular challenge to the translator and which for the moment I will indicate simply as the Comedy's intertextuality.

\section{A Personal Approach}

Of all recent Dante translators, Jacques Janssen is most explicit and most personal about the motives that have driven him to his huge enterprise. He even announces his program in the title of his translation: Mijn Komedie: Hel [My Comedy: Hell]. Janssen tells us in his introduction how one of his seminary teachers inspired his love and admiration for Dante's poetry and how many years later he began to translate:

My interest in Dante increased, but the idea to translate his complex work never came to my mind. I just started, in 1994, on an impulse and out of irritation. I did not understand why the Divina Commedia, which I always hear when I am reading it, cannot be read aloud in a Dutch translation, and why, moreover, it sounds so much more complicated and elevated than the original. ${ }^{9}$

Working at his translation Janssen was fully aware that this work was a 'drudgery or, better, a hell of a job', ${ }^{\text {IO }}$ but he did not give up, at all times keeping in mind his irritation about the existing Dutch translations: 'Moreover, I wanted a translation that could be read aloud.'II

Janssen does not have any illusions, however, as to the inadequacy of any attempt to translate Dante's poetry, and he even refers to the passage of the Convivio where Dante states that it is impossible to translate poetry:

E però sappia ciascuno che nulla cosa per legame musaico armonizzata si può della sua loquela in altra transmutare sanza rompere tutta sua dolcezza ed armonia. E questa è la cagione per che Omero non si mutò di greco in latino, come l'altre scritture che avemo da loro. E questa è la cagione per che i versi del Salterio sono sanza dolcezza di musica e d'armonia: ché essi furono transmutati d'ebreo in greco e di greco in latino, e nella prima trasmutazione tutta quella dolcezza venne meno.

(Convivio, I, VII, I4-I5) 
Although suggesting that he is giving a translation of this passage, Janssen in reality gives a kind of summary:

All poetry is by definition untranslatable, because it is impossible to put its harmony and music in another language. That is the reason why we cannot experience the beauty of the psalms, and why it is better to leave Homer untranslated. ${ }^{12}$

The liberty with which Janssen translates this prose fragment could frighten the reader, who might consider it a foreboding of his translation of poetry. However, this passage is not representative of Janssen's approach to translating the Inferno. It will be better to take this reference as a token of his familiarity with Dante's works and to believe in the honesty of a translator who, basing himself on the author of the Convivio, expresses his hope that the inadequacy of his results will stimulate the reader to address the original.

Janssen presents a translation in prose, with the lines arranged as if it were poetry, probably in order to reinforce the suggestion that the text be read aloud. His ambition is first and foremost to offer a readable text to the modern Dutch public. However, his ambition goes further: the reader is offered a rich apparatus of short introductions to each canto and quite a few notes with historical, geographical, and cultural clarifications. An unusual aspect of these notes which in a way is a textual equivalent of the numerous illustrations from all times that embellish this edition - are the references to literary texts ranging from Boccaccio to Thomas Mann and Umberto Eco. As these references are not introduced in any systematic way, they seem to testify chiefly to the culture of the translator, who in this way personalizes his comments. This personal dimension gives a special quality to the whole of the work of this translator who, being a modern Dutch Roman Catholic, explicitly identifies with Dante's spiritual adventure:

The Christian has to undertake a long and complicated journey. I make that journey with Dante, and I love the complexity of the undertaking. Gradually, and that is the big secret of Dante, a strong bond is growing between reader and writer. [...] He made his journey; it is a journey of all times. His Comedy is my comedy. I follow in his footsteps. Silently, we go as friars one behind the other, the eldest one first: 'Tu sarai primo e io sarò secondo'. I hear the footsteps, which get the poem going. ${ }^{\mathrm{I3}}$

Perhaps in the last sentence we may hear an echo of Osip Mandelstam's famous essay on Dante, ${ }^{\mathrm{I}}$ and perhaps we may read in the whole passage a connection between religious experience and the rhythm of the poem. However, in his introduction Janssen does not even mention the problems of translating Dante's 
rhythm, as if his choice to translate the poem into prose and to arrange this prose as if it were poetry had liberated him automatically from all such problems.

\section{Rhyme and Rhythm}

Together with the problems of rhyme, the problems of translating Dante's rhythm are at the centre of attention in the one page preface of Ike Cialona and Peter Verstegen to their Goddelijke Komedie. These translators rightly claim that theirs is the first rhymed and metrical translation after that of Albert Verwey of 1923. ${ }^{\text {I5 }}$ Perhaps implicitly criticizing the result obtained by Verwey, Cialona and Verstegen declare it was their ambition to transfer Dante's poem into a form of poetry that would sound natural to a Dutch ear. Which does not mean, however, that they intended to limit themselves to the spoken Dutch of today (which, on the other hand, seems to have been precisely Janssen's ambition): 'Our objective was to translate this epic into understandable, not necessarily contemporary Dutch.' ${ }^{\text {'6 }}$

The sacrifices at the level of content caused by the constraints of meter and even more of rhyme are accepted by these translators without making so much as a problem of it: 'In a poetical translation a part of the content always gets lost.' ${ }^{\text {'7 }}$ The scrupulous reader who might have some difficulties with this position is invited to read the footnotes, or at least many of them: '[...] whoever wants to know exactly what Dante is saying will often [my italics] benefit from our notes'. ${ }^{18}$ The principal objective of Cialona and Verstegen's translation is the poetical form of the Divina Commedia:

From the historical, rhetorical, and compositional point of view the Comedy is of a unique richness; but it is first of all a poem, a work wherein the ideas are supported by the music of measure and rhyme, rhythm, alliteration and assonance. ${ }^{\mathrm{I}}$

Here comes to mind what Dante says in the Convivio about the impossibility of translating poetry. One may formulate a hypothesis about Cialona and Verstegen's reaction to that position: they might say that in an attempt to 'transmute' poetry from one language into another, one may also try to maintain the 'dolcezza' and 'armonia', if only one is ready to sacrifice some aspects of the content. We will see that their reaction might have convinced even Dante himself.

Cialona and Verstegen present their edition in two volumes. The first volume contains the Dutch text with the complete collection of Dante engravings by Gustave Doré. The second volume presents, after a short introduction, the Italian text and the notes, which are less elaborate than Janssen's and which often give only the literal prose translation of a line Cialona and Verstegen have translated more freely in the rhymed version. All things considered, this translation is presented as a poem in Dutch, which should be read with the Italian text and the 
notes in the background. Cialona and Verstegen's approach has artistic ambitions, although it lacks signs of personal engagement, and at the same time, it is more didactic than Janssen's. Rather surprising is the fact that the first canto of the Inferno is presented as a 'prologue', both in the Dutch translation and in the Italian text, and that the Inferno begins with the second canto. Nobody will contest the function of the first Inferno canto as prologue to the whole poem, but the typographical emphasis on that function here is unique - as far as I know in the entire editorial tradition of Dante's poem.

\section{Understanding Dante's Complexity}

De Goddelijke Komedie translated by Rob Brouwer and published in three volumes, Inferno (2000), Purgatorio (200I) and Paradiso (2002), ${ }^{20}$ represents the most complex approach to the problem of a Dutch translation of the Divina Commedia, contrary to what the Italian titles of the three canticles may suggest. Just like Cialona and Verstegen, Brouwer has opted for a verse translation, but he presents the Italian text on the opposite page and does not submit himself to the constraints of the terza rima:

The translation presented here with the Italian text of Petrocchi on the opposite page is written in blank verse, alternating hendecasyllables and decasyllables. End rhyme has been abandoned, but all kinds of internal rhymes, assonances, and alliterations have been admitted and seized wherever this was possible without forcing. ${ }^{21}$

To have abandoned end rhyme may seem an easy solution, but this is compensated by the fact that in his translation Brouwer does not want to give up the various semantic nuances of Dante's original. In his preface Brouwer tells us that he has submitted the first versions of his translation to his wife, to check 'whether it was immediately comprehensible, whether it was beautiful enough and whether the res metricae were correct'; ${ }^{22}$ he submitted these first versions also to the Italianist Ronald de Rooy to check their accuracy. It is this attitude of putting himself constantly at the disposal of the critical reader that distinguishes Brouwer's approach. He furthermore asked De Rooy to write a general introduction, he himself adding a second introduction on the classical sources of Dante's work. Every canto is introduced by means of a relatively long synopsis, and every canto is followed by short essays with further explanations and comments. In his preface, the translator calls himself 'a schoolmaster by profession', and he is concerned about readers who might consider his comments superfluous. As a really modern teacher, however, he leaves the decision of whether to follow him or not to the responsibility of the individual reader.

The personal engagement declared by Brouwer is certainly not inferior to that of Janssen, but Brouwer's engagement is directed purely towards interpretation. 
More than our other translators, Brouwer is concerned about the correctness of his interpretation and of single interpretations in general. He wants to understand and he wants his readers to understand the full complexity of Dante's words. Hoping that this will not be misunderstood as the opposite of a compliment, one could say that, separate from the translation in itself, Brouwer's essays may be read together as a study that represents an important contribution to the comprehension of the Divina Commedia.

\section{Dante the Translator}

After having discussed the intentions, the formal strategies and the different types of comments adopted by our translators, we may now ask ourselves to what extent these translations correspond to the original text. The answer to this question could only be attained through a full and systematic comparison based on the categories of modern translation theory, a work that should certainly be undertaken in the near future. Here, however, I prefer to concentrate on one specific aspect of the translations: the way in which they deal with some of the passages of the Divina Commedia that are themselves translations from classical or biblical Latin texts.

My set of examples will be based on a recent study by Massimiliano Chiamenti, Dante Alighieri Traduttore, ${ }^{23}$ in which the author examines all passages in Dante's works that can be considered translations from other languages, mostly from Latin. The fact that Dante's intertextuality is often based on translation is generally known and is mentioned in all comments, not excluding those of our Dutch translators. Chiamenti, however, studies this phenomenon systematically, basing himself on the categories of modern translation theory, which could also guide the comparison between the recent Dutch translations. Therefore, I dare to hope that the examples I have selected, apart from showing how Dante himself operated as a translator, also have an added value as far as method is concerned.

Chiamenti, in applying P. Newmark's categories, ${ }^{24}$ has arranged his study in such a way that the various chapters concentrate on different translational strategies adopted by Dante himself. Chiamenti observes the Florentine poet transferring words from a foreign language directly into his own text (chapter II), translating literally word-for-word (chapter III), remaining faithful to the original text, with 'high fidelity' (chapter IV), modulating the original allowing various shifts (chapter V) or, finally, translating freely and allowing important shifts (chapter VI). Chiamenti illustrates all these approaches with an impressive number of examples.

Particularly interesting among Chiamenti's conclusions is the fact that Dante is not always consistent with what he stated in the Convivio about the impossibility of translating the 'dolcezza' and the 'armonia' of a text in one language into a text in another language. We have seen that Dante himself illustrates this impossibility 
by referring to the psalms. Chiamenti, however, quotes some passages of the Comedy, in which Dante speaks of the 'dolcezza' of some verses of the psalms in Latin. According to the theory of the Convivio, these Latin verses should have lost 'tutte quelle dolcezze' already in the 'transmutazione' from Hebrew to Greek:

Quando fui presso a la beata riva, 'Asperges me' sí dolcemente udissi, che nol so rimembrar, non ch'io lo scriva.

(Purg. 3I, 97-99) [Ill. 6, Pulgatorio 3I]

And:

'Deus, venerunt gentes,' alternando or tre or quattro dolce salmodia,

le donne incominciaro, e lagrimando; (Purg. 33, I-3) [Ill. 7, Pulgatorio 33]

In the translation by Cialona and Verstegen these lines sound, respectively:

Tot, van de oever der gebenedijden,

Zo'n wonderzoet 'Ontzondig mij...' weerklonk

Dat ik het niet met woorden wil ontwijden.

And:

'O God, de heidenen die binnendrongen...'

Werd wenend, in herhaalde wisseling,

Door nu drie vrouwen, dan weer vier, gezongen;

Brouwer translates these tercets as follows:

Vlak bij de oever van 't geluk vernam ik

Een lieflijk en zó teer Asperges me

Dat mijn geheugen én mijn pen tekortschiet.

Deus venerunt gentes, beurtelings hieven

De vrouwen van dat trio en 't kwartet

Dit psalmvers aan, 't klonk lieflijk, maar ze huilden 
Not only does Dante credit the Latin translations of the psalms with 'dolcezza', these lines are also an example of what Chiamenti calls the first mode of Dante's translations, where 'translating' is taken in the literal sense of 'transferring', meaning the direct transfer of words of a foreign language into the Italian text. Moreover, in the Dutch translations there is a clear difference between the solutions adopted by Cialona and Verstegen on the one hand and by Brouwer on the other. In the first tercet Cialona and Verstegen have translated 'dolcemente' with 'wonderzoet' ('wonderfully sweet'), but in the second tercet they have eliminated not only 'dolce' but also 'salmodia'. By translating 'asperges me' with 'ontzondig mij' ('free me from sins'), they have created a new intertextual reference to the translation of Psalm $5 \mathrm{I}$ in the Authorized Dutch Version of the seventeenth-century Bible, which in a way may compensate the reader for the loss of Dante's own terms. Brouwer gives a more faithful translation, maintaining the Latin words and the reference to the psalm, and translating both 'dolce' and 'dolcemente' with 'lieflijk' ('sweet').

These translators also deal differently with the references to Psalm $5 \mathrm{I}$ in the first tercet and to Psalm 79 in the second one. None of them forgets to mention these intertextual references in their notes, but Cialona and Verstegen just indicate Psalm $5 \mathrm{I}$ as the source for the second verse of the first tercet and curiously consider the first verse of the second tercet a 'paraphrase' of the first verse of Psalm 79. Brouwer's comment briefly dwells on 'asperges me' but gives a long and interesting interpretation of 'Deus venerunt gentes' and the verses that follow in the Vulgate.

In a comparison of translations from the Purgatorio, we could not include the work of Jacques Janssen who, until now, has translated only the Inferno. However, it is not difficult to formulate a hypothesis about the solution Janssen would have adopted in this case, for we know his solution for an analogous problem in the first verse of Inferno 34:

"Vexilla regis prodeunt inferni

verso di noi; però dinanzi mira,»

disse 'l maestro mio, «se tu 'l discerni».

(Inf. 34, I-3)

Janssen translates as follows:

Toen zei mijn meester: 'Vexilla regis

prodeunt inferni. Kijk goed

voor je uit, of je hem zien kunt.

One may therefore plausibly suppose that Janssen, had he translated the Purgatorio, would have maintained the Latin words in the previous fragments. 
Our other translators show themselves in these verses consistent with the choices they adopted in the Purgatorio: Cialona and Verstegen eliminating the Latin and stating their overall choice in a footnote ('The Latin quotations in the Commedia have been translated into Dutch'25), and Brouwer maintaining the Latin verse:

Cialona and Verstegen:

'De hellevorst treedt met zijn vaandels aan!

Hij is nabij.' Mijn gids heeft mij bevolen:

'Kijk recht vooruit, of je hem ziet staan.'

Brouwer:

\section{'Vexilla regis prodeunt inferni}

op ons af, kijk daarom maar scherp vooruit,'

aldus mijn meester, 'of je hem al zien kunt !'

The different translations of this particular tercet lend themselves to a further comparison in that they seem representative not only of the way the translators handle Dante's Latin, but also of some other characteristic aspects of their translational strategies. Janssen's translation skips 'verso di noi' and is formulated in a very colloquial, perhaps even too colloquial, Dutch.

The first line of the translation of Cialona and Verstegen does not respect Dante's Latin, but their Dutch verse has a solemn tone and rhythm, which certainly do respect his style. However, it is followed by a second line where the constraints of feminine rhyme result in a transformation of the Italian passato remoto 'disse' into the Dutch perfect 'heeft bevolen' ('has commanded') which is very ugly by any standard of Dutch narrative grammar.

Brouwer is very clever in respecting the movement of the tercet and is very faithful to the text, but the transition from the Latin verse to the Dutch 'op ons af' ('towards us') seems far more abrupt than the transition toward the Italian 'verso di noi', where the transition is made smoother by the etymological connections between the two languages. One could come to prefer Janssen's solution of eliminating 'verso di noi'. Anyway, it is clear that the ambition to respect Dante's plurilinguism may create problems which cannot be solved easily, even when we set aside the difficulty (for a rhyming translator who also wants to respect the Latin) of finding in Dutch a word which rhymes with 'inferni'.

\section{High Fidelity}

Passing over the examples which are classified by Chiamenti under the type 'one to one' (i.e. literal translation) and under the type 'modulations' (i.e. translations 
somewhere between faithful and free), I would like to present two other examples from his study, a very simple example of 'high fidelity' and his most complex example of Dante's way of translating.

The example of 'high fidelity' is to be found in the first line of the tercet Inferno I0, 25-27:

La tua loquela ti fa manifesto

di quella nobil patrïa natio

a la qual forse fui troppo molesto»

'La tua loquela ti fa manifesto' is the faithful translation of Matthew 26:73: 'loquela tua manifestum te facit'. In our translations, this verse in its context sounds as follows:

Janssen:

'...Aan uw tongval is duidelijk te horen

dat $\mathrm{u}$ in dat nobele vaderland geboren bent,

dat ik misschien te veel schade

berokkend heb. ${ }^{26}$

Cialona and Verstegen:

'Ik ken je door je tongval als Toscaan,

In de voorname vaderstad geboren

Waar ik misschien te veel aan heb misdaan. ${ }^{27}$

Brouwer:

Je spraak verraadt dat jij met mij gemeen hebt

Dat edele vaderland, waaraan ikzelf

Misschien wel te veel onheil heb berokkend. ${ }^{28}$

It is clear that none of our translators shows Dante's 'high fidelity' to the sentence in the Gospel of Matthew, although Brouwer comes very near to the text as it sounds in Matthew 26:73 of the Dutch Willibrord translation, where people accuse Peter of belonging to the group of Jesus saying, 'je spraak verraadt je' ('your speech betrays you'). However, neither Brouwer nor the other translators use the commentary to mention the source of the verse, as is customary in nearly all Italian editions.

Maybe our translators considered the relationship between Dante's verse and the sentence in the Gospel as not specific enough. Nevertheless, in its not being 
justified by the specific context, the reference seems nonetheless a good example of the cultural density and stratification of Dante's language, even where apparently it seems merely 'banal'. There may be no doubt that one of the tasks of a translator is to render this cultural density into his own language, obviously in balance with a large number of other exigencies.

\section{'Fidandomi di me'}

The most complex example is given by Chiamenti in his final chapter entitled Fidandomi di me, which is Dante's expression for justifying his use of the Italian language in the comments to the canzoni of the Convivio. Rather than running the risk of an incompetent person giving an ugly translation in 'volgare' of the Latin comments, the poet preferred to write these comments in 'volgare' himself, 'fidandomi di me più che d'un altro' (Convivio, I, X, IO). ${ }^{29}$

This is also the chapter where Chiamenti examines Dante's translational practice as opposed to his own famous theory about the impossibility of translating poetry. The example Chiamenti uses is a Purgatorio tercet in which Statius addresses Virgil, expressing his admiration for the Latin poet and quoting some verses from his fourth eclogue:

Facesti come quei che va di notte,

che porta il lume dietro e sé non giova,

ma dopo sé fa le persone dotte,

quando dicesti: 'Secol si rinova;

torna giustizia e primo tempo umano,

e progenïe scende da ciel nova'.

(Purg. 22, 67-72)

Of these two tercets the second is a translation of lines 5-7 of Virgil's fourth eclogue:

Magnus ab integro saeclorum nascitur ordo;

iam redit et Virgo, redeunt Saturnia regna,

iam nova progenies caelo demittitur alto.

In the nearly literal prose translation in the Dante commentary by Anna Maria Chiavacci Leonardi, these verses are rendered as follows:

Una grande serie di secoli ricomincia di nuovo: ritorna la Vergine Astrea, ritorna il regno di Saturno; dall'alto del cielo discende una nuova progenie. ${ }^{30}$ 
Dante, however, manages to give a translation in a single tercet and is thus constrained to what Chiamenti calls a 'leggera compressione' ${ }^{31}$ Chiamenti gives a very meticulous and complete description of the various transformations that Virgil's lines have undergone before arriving in Dante's tercet. ${ }^{32}$ Here I can only sum up the main elements of these transformations.

The first Latin hexameter is concentrated by Dante, not in a whole but in a half hendecasyllable, deleting 'magnus ab integro [...] ordo' and eliding from 'saeclorum ordo' to 'Secol', with analogy of the signifier but not of the signified, which shifts semantically from 'a very long era' to 'the whole terrestrial world'. The Italian verse finishes with 'rinova', which translates and reinforces 'nascitur' and is a reminder of 'ab integro' and at the same time anticipates the last word of the last verse 'nova', which is literally taken from the last Latin verse.

From the second and third hexameter Dante eliminates the anaphora 'iam [...] iam' and the repetition 'redit [...] redeunt' for the sake of 'leggerezza'. With a modulation based on his own Monarchia (I xi I), he translates 'Virgo' with 'giustizia' and 'Saturnia regna' with 'primo tempo umano'. In his Italian translation, Dante shifts the ordo naturalis of the Latin 'nova progenies' into a hyperbaton ('progenïe [...] nova'). However, as has been observed by Gianfranco Contini, who is quoted by Chiamenti in a footnote, this hyperbaton may be considered an equivalent of the Latin 'caelo $[\ldots]$ alto'..$^{33}$

In the same long footnote, Chiamenti quotes a whole list of observations from various important Italian scholars. I will not summarize this footnote, for I think even my summary of Chiamenti's description is convincing enough to accept the judgment of one of these scholars, Mario Fubini, that we are dealing here with a 'masterful translation'34 and to also accept Chiamenti's own judgment that Dante's translation is 'an empirical denial [...] of the dogma that poetry cannot be translated'. 35

Neither Cialona and Verstegen nor Brouwer give any sign of taking up the challenge to translators implied in this tercet. Cialona and Verstegen characterize it as a 'paraphrase' of Virgil's famous verses, and Brouwer simply observes that Virgil is confronted with a quotation of his own eclogue. But let us read their translations.

Cialona and Verstegen:

U deed als iemand die, van zelfzucht vrij,

Des nachts zijn lamp niet voor zichzelf laat stralen,

Maar zijn gezellen bijlicht, toen u zei:

'De eerste Gouden Eeuw zal zich herhalen;

Gerechtigheid keert naar de aarde weer;

Een nieuw geslacht zal uit de hemel dalen. ${ }^{36}$ 
Brouwer:

Gij deed als een die in de nacht op weg

Met op zijn rug een lamp die hém niet baat,

Maar wel het inzicht schenkt aan wie hem volgen,

Toen gij ooit dichtte: 'n Nieuw bestel breekt aan,

Gerechtigheid keert weer en 't eerste Tijdperk,

En uit de hemel daalt een nieuw geslacht.'37

Limiting our considerations to the second tercet, it is clear that Cialona and Verstegen have put 'quando dicesti' in the preceding tercet and that they do not follow the course of the three verses in which each verse provides new information. In fact, their first two lines are a translation of the second line in Dante's tercet. But one could say that they have concentrated 'secol si rinova' from the first line and 'torna [...] primo tempo umano' from the second one in their first line 'De eerste Gouden Eeuw zal zich herhalen' ('The first Golden Age will repeat itself'). Here, 'De Gouden Eeuw' seems an acceptable translation of 'primo tempo umano', an expression that is also explained in the commentary. Cialona and Verstegen could even have referred to the passage in the Monarchia quoted by Chiamenti where Dante himself identifies 'Saturnia regna', 'optima tempora' and 'Aurea [tempora]'.

Brouwer rigorously respects the distribution of information in Dante's three verses, and also the repetition of 'rinova' and 'nova' (lost in the translation of Cialona and Verstegen), in the repetition of 'nieuw' in the second and the third line. Some doubts could arise about 'bestel' ('ordainment') for 'secol', which seems a reminiscence of Virgil's 'ordo' rather than a translation of Dante's 'secol'. If this were the case, we would be dealing with a very interesting direct echo of Dante's source text, a procedure that seems justified by the practice of the poet himself.

\section{The Role of the Critic}

Obviously, these few examples are not enough even to begin to formulate a judgment on the overall quality of the three recent Dutch translations. However, I hope to have given some impression of what the translators have intended to do and a first impression of what they have actually achieved. Above all, I hope to have indicated a fruitful method to participate in the work of translators by studying not only Dante's theory of translation, but also, and perhaps even more, his translational practice. One could object that in the Divine Comedy Dante presents the numerous translated verses as his own, and that I have indicated a valid method to participate in the work of poets rather than in that of translators. This 
objection, however, would be based on a very rigorous distinction between the activities of writing poetry and translating. Perhaps such a distinction is supported by certain theories, from the Middle Ages up to our own days, and also, as we have seen, by Dante's own theory. However, this distinction is certainly disavowed by the practice of writing poetry, from the Middle Ages up to our own days, Dante's poetry not excluded.

One could still object that the critic's task is to judge the work of translators rather than to participate in it, and that the method I have indicated will lead astray. However, even this distinction does not seem to be valid in all cases, and it surely is not valid in the case of the Divine Comedy. The recent flourishing of Dutch translations certainly does not mean the end of the efforts to translate Dante in the Netherlands. We may be rather confident that new translators and/or poets are already preparing themselves and that they will want to reflect on the work of their predecessors, just like our translators have reflected on the various commentaries and experiences of their predecessors. In my view, one of the most important functions a critic may aspire to is to have his judgments play a role in the ever-continuing work of transmission and translation of that splendid patrimony of literary and cultural values represented by the Divina Commedia. 


\section{Notes}

\section{Notes Ronald de Rooy, Divine Comedies for the New Millennium. Humbleness and Hubris}

I The Inferno of Dante Alighieri: canto I-XXXIV, With a Translation in English Blank Verse, Notes, and a Life of the Author, London, J. Carpenter, 2 vols., I805-I806; The Vision: or, Hell, Purgatory, and Paradise, of Dante Alighieri, Translated by the Rev. H.F. Cary, London, H. Frowde, I8I4.

2 Thomas William Parsons, The First Ten Cantos of the Inferno of Dante Alighieri, Boston, William D. Tickner, I843; The First Canticle of the Divine Comedy of Dante Alighieri, Boston, De Vries, Ibarra, I867.

3 The Divine Comedy of Dante Alighieri, 3 vols., Boston, Ticknor and Fields, 1867.

4 Two fundamental studies on the first century of Dante translations in America are those of Angelina La Piana, Dante's American Pilgrimage. A Historical Survey of Dante Studies in the United States I80o1944, New Haven, Yale University Press, 1948, and William J. De Sua, Dante into English: a Study of the Translation of the Divine Comedy in Britain and America, Chapel Hill, University of North Carolina Press, 1964 .

5 There are many studies on Dante's presence in modern Anglo-American prose and poetry. The most important ones include: Carole Ann Slade, The Straight Way Was Lost: Parallels between Dante's Inferno and Five Twentieth-Century Novels, doctoral dissertation, New York University, I974; David Wallace, Dante in English, in Rachel Jacoff, ed., The Cambridge Companion to Dante, Cambridge, Cambridge University Press, 1994, pp. 237-258; Nick Havely, ed., Dante's Modern Afterlife. Reception and Response from Blake to Heaney, Houndmills, Basingstoke, Hampshire and London, Macmillan Press Ltd, I998; Peter S. Hawkins and Rachel Jacoff, eds., The Poets' Dante. Twentieth-Century Responses, New York, Farrar Straus \& Giroux, 20oI; Maria Cristina Fumagalli, The Flight of the Vernacular. Seamus Heaney, Derek Walcott and the Impress of Dante, Amsterdam - New York, Rodopi, 200 I.

6 For bibliographical details on the Dutch and American Dante translations mentioned in this table, I refer to the bibliography at the end of this volume.

7 In fact, while putting the finishing touches on this introduction, in March 2003 one more American Dante translation became available: The Divine Comedy of Dante Alighieri: Purgatorio, Edited and Translated by Robert M. Durling, Introduction and Notes by Ronald L. Martinez, Illustrations by Robert Turner, New York, Oxford University Press, 2003.

8 Dante Alighieri, Inferno, Translated by Henry Wadsworth Longfellow, Edited by Matthew Pearl, Introduction by Lino Pertile, New York, Modern Library, 2003.

9 The Divine Comedy of Dante Alighieri, with translation and comment by John D. Sinclair, Inferno, New York, Oxford University Press, 1939; The Divine Comedy of Dante Alighieri, with translation and comment by John D. Sinclair, 3 vols., London, John Lane, I946.

IO http://www.princeton.edu/ - dante

II Note on the Translation, in Dante Alighieri, Inferno, Translated by Robert \& Jean Hollander, Introduction \& Notes by Robert Hollander, New York, Doubleday, 200o, p. IX.

I2 Ibid., p.VII.

I3 Ibid., p. IX.

I4 http://www.wordsmith.org/chat/hollanders.html

Is Dante Alighieri, De Goddelijke Komedie, vertaling in terzinen door Albert Verwey, Haarlem, Tjeenk Willink \& Zoon, I923.

I6 Dante Alighieri, The Divine Comedy, Translated, with a Commentary by Charles S. Singleton, Princeton, Princeton University Press, I970 (Inferno), 1973 (Purgatorio), I975 (Paradiso); as Robert 
Hollander has pointed out in the foreword to his own translation, Singleton's version in turn relies heavily on the prose translation by John D. Sinclair: 'Thus, having decided to begin with Sinclair and to modify him, we found that Singleton had apparently done essentially the same thing.' (Note on the Translation, cit., p. VIII).

I7 Dante Alighieri, De goddelijke komedie, vertaald, ingeleid en toegelicht door Frans van Dooren, Baarn, Ambo, 1987. In the period 1987-2003, there have been more than eight editions of this translation, with a total of approximately 25,000 copies being sold (cf. Paul van Heck's article elsewhere in this volume).

I8 Two important reviews of Van Dooren's translation are those by Pieter de Meijer, Dante vertalen, in «Incontri», vol. 3, 3-4 (1988), pp. 202-205, and Paul van Heck, Een nieuwe Dante-vertaling, in «De Gids", vol. I52, II (1989), pp. 9II-918.

I9 The Inferno of Dante, A new verse translation by Robert Pinsky, Illustrated by Michael Mazur, With notes by Nicole Pinsky, Foreword by John Freccero, New York, Farrar Straus \& Giroux, 1994; Dante Alighieri, The Divine Comedy: Hell, Purgatory, Heaven, A Terza Rima Version by Peter Dale, London, UK, Anvil, 1996; Dante Alighieri, Purgatorio, A New Verse Translation by W.S. Merwin, New York, Alfred A. Knopf, 20oo; Dante Alighieri, Inferno, A New Verse Translation by Michael Palma, New York, W.W. Norton \& Company, 2002.

20 Dante Alighieri, De goddelijke komedie, Met alle prenten van Gustave Doré, Vertaald door Ike Cialona en Peter Verstegen, Amsterdam, Athenaeum-Polak \& Van Gennep, 2000, 2 vols.

2I Dante Alighieri, Inferno, Translated by Robert \& Jean Hollander, Introduction \& notes by Robert Hollander, New York, Doubleday, 20oo; Dante Alighieri, Purgatorio, A Verse Translation by Jean Hollander \& Robert Hollander, Introduction \& notes by Robert Hollander, New York, Doubleday, 2003.

22 Dante Alighieri, De goddelijke komedie. Deel I: Inferno, Vertaald door Rob Brouwer, Met een inleiding door Ronald de Rooy, Leiden, Primavera Pers, 20oo; Dante Alighieri, De goddelijke komedie. Deel II: Purgatorio, Vertaald door Rob Brouwer, Leiden, Primavera Pers, 20oI; Dante Alighieri, De goddelijke komedie. Deel III: Paradiso, Vertaald door Rob Brouwer, Leiden, Primavera Pers, 2002.

23 W.S. Merwin, Poetry Rising from the Dead, in The Poets' Dante, edited by Peter S. Hawkins and Rachel Jacoff, cit., pp. 292-305, p. 295 .

24 The Divine Comedy of Dante Alighieri. Inferno, Edited by Robert M. Durling and Ronald L. Martinez, New York, Oxford University Press, 1996, p. 405.

25 Dante Alighieri, Mijn komedie. Deel r: Hel, Vertaald, ingeleid en geannoteerd door Jacques Janssen, Nijmegen, Sun, 1999, p. 295: "Brothers," I said, "we have escaped from a hundred thousand perils on our journey to the west. I hope the short time that remains will not prevent us, on our journey following the sun, from knowing the uninhabited world. Be aware of your origin. You were not made to live like beasts, but to pursue virtue and knowledge."'

26 Dante Alighieri, Inferno, Translated by Robert \& Jean Hollander, cit., pp. 446-447.

27 Dante Alighieri, De goddelijke komedie. Deel I: Inferno, Vertaald door Rob Brouwer, cit., p. 455: "My brothers, who have endured countless dangers on the journey to the West," I said, "do not deny to the brief remaining vigil of your lives the sensual pleasure of a world beyond the sun, a wide world without people. Consider that you were not conceived to live like brute beasts, but only to pursue virtue and knowledge."'

28 The Inferno of Dante, A new verse translation by Robert Pinsky, cit., p. 277.

29 Robert Pinsky, Translator's note, in ibid., p. XXI.

30 Ibid., p. XXII.

3 I Ibidem.

32 Ibid., p. XXIII.

33 Ibidem.

34 Dante's Inferno, With a translation into English triple rhyme by Laurence Binyon London, Macmillian and Co., Ltd., 1933; Dante's Purgatorio, With a translation into English triple rhyme by 
Laurence Binyon, London, Macmillian and co., limited, 1938; Dante's Paradiso, With a translation into English triple rhyme by Laurence Binyon, London, Macmillian and Co., 1943.

Cf. Ezra Pound, Hell [1934], in Literary Essays of Ezra Pound, Edited with an Introduction by T.S. Eliot, London, Faber and Faber, 1985 [first ed. 1954], p. 209: 'Not having worked into the idiom, one is annoyed by inversions and extra words. Shadwell, if I remember rightly, tried an eight syllable line to get a weight equal to the Italian. I don't know that anyone has thought of attempting the poem in terza rima, but with fewer English lines than the Italian. It would breed, probably, considerable confusion, it might cause a denseness that would defeat the main end: penetrability.' As Theodore J. Cachey Jr. has noted, Pound returns to this problem in his correspondence with Laurence Binyon (cf. Between Hermeneutics and Poetics: BinBin's Dante Revisited, in Dante e Pound, ed. by Maria Luisa Ardizzone, Ravenna, Longo, 1998, pp. 167-187).

36 Robert Pinsky, Translator's note, cit., p. xxiii.

37 Theodore J. Cachey, Jr., The Inferno of Dante: A New Verse Translation, in «Lectura Dantis», I8-I9, Spring-Fall (1996), pp. 134-138, p. I38.

38 Dante Alighieri, Inferno, A New Verse Translation by Michael Palma, cit., p. 293.

39 Michael Palma, Introduction, in ibid., p. xv.

40 Ibid., p. xvi.

4I Ibid., p. xvii.

Ike Cialona and Peter Verstegen, Inleiding, in Dante Alighieri, De goddelijke komedie, Met alle prenten van Gustave Doré, Vertaald door Ike Cialona en Peter Verstegen, cit., p. 5. In comparison with the other recent translations, the Cialona/Verstegen translation has received much attention in Dutch newspapers and journals. A selection from the many reviews: Kees Fens, De Volkskrant, I-I2-2000; David Rijser, Overdonderd door Dante, in NRC Handelsblad, I-I2-2000, p. 35; Ton van Deel, Vertel mij wat u hebt misdaan, in Trouw, 23-12-2000, p.53; Frans Denissen, De Morgen, 27-I2-2000; Christine D'haen, Goddelijk, al te menselijk, in Standaard der Letteren, 2I-I2-2000, p. I2; Ronald de Rooij, Tussen 'Sinterklaas-gedicht' en 'gebeurtenis'. Analyse van een nieuwe Dante-vertaling, in «Incontri» 16/3-4 (200I), pp. I2I-I34.

44 Dante Alighieri, De goddelijke komedie, Met alle prenten van Gustave Doré, Vertaald door Ike Cialona en Peter Verstegen, cit., p. 210: ' "O brothers," I said, "who have had to suffer a lot, / You are, despite the dangers, close to the west. / Please prepare yourselves / In the remainder of our lives / To find a world in which no people live; / We search that region in the trail of the sun. / Consider your origin: we are not allowed / To live like the brute beast; / We should pursue virtue and knowledge."” Cf. in this volume, pp. 59-73.

46 Cf. Teodolinda Barolini, The Undivine Comedy. Detheologizing Dante, Princeton, Princeton University Press, 1992, pp. 53-58.

\section{Notes Paolo Cherchi, The Translations of Dante's Comedy in America}

I Angelina La Piana, Dante's American Pilgrimage. A Historical Survey of Dante Studies in the United States, I880-1944, New Haven, Yale University Press, 1948.

2 William J. De Sua, Dante into English. A Study of the Translation of the Divine Comedy in Britain and America, Chapel Hill, University of North Carolina Press, 1964.

3 The Divine Comedy in English. A Critical Bibliography, [I782-1966], 2 vols., New York, Barnes \& Noble, I965 and 1967.

4 One exception is Theodore J. Cachey, Jr., Between Hermeneutics and Poetics - Modern Translations of the Commedia, in "Annali d'Italianistica", 8, 1990, pp. I44-I55; L'odissea del Dante americano, in «Belfagor», 55:3, 327 (2000), pp. 328-335.

5 The First Ten Cantos of the Inferno of Dante Alighieri, Boston, William D. Tickner, 1843.

6 The First Canticle of the Divine Comedy of Dante Alighieri, Boston, De Vries, Ibarra, I867. 
7 The Ante-Purgatorio of Dante Alighieri, Cambridge, Massachusetts, J. Wilson and Son, I875.

8 The Divine Comedy of Dante Alighieri, 3 vols., Boston, Ticknor and Fields, I867.

9 The Divine Comedy of Dante Alighieri, Vol. I. Hell, Boston and New York, Houghton Mifflin and Company, I891; The Divine Comedy of Dante Alighieri, Vol. II. Purgatory, Boston and New York, Houghton Mifflin and Company, 1892; The Divine Comedy of Dante Alighieri, Vol. III. Paradise, Boston and New York, Houghton Mifflin and Company, I892.

Io The Divine Comedy of Dante; The Inferno, New York, Charles Scribner's Sons, 1904.

II La Commedia di Dante Alighieri; The Divine Comedy, translated by Henry Johnson, New Haven, Yale University Press, I9I5.

I2 The Divine Comedy of Dante Alighieri; Vol. I. Inferno, the Italian text with a translation in English blank verse and a commentary by Courtney Langdon, Cambridge, Mass., and London, Harvard University Press, 1918; The Divine Comedy of Dante Alighieri; Vol. II. Purgatorio, the Italian text with a translation in English blank verse and a commentary by Courtney Langdon, Cambridge, Mass., and London, Harvard University Press, 1920; The Divine Comedy of Dante Alighieri; Vol. III. Paradiso, the Italian text with a translation in English blank verse and a commentary by Courtney Langdon, Cambridge, Mass., and London, Harvard University Press, I92I.

I3 The Divine Comedy of Dante Alighieri, translated by Jefferson Butler Fletcher, New York, MacMillan, I933.

I4 Here beginneth the Comedy of Dante Alighieri, Florentine by birth but not by conduct; Part I, Hell, American translation by Louis How, New York, The Harbor Press, 1934; The Comedy of Dante Alighieri, Florentine by birth but not in conduct; Part II, Purgatory, American translation by Louis How, New York, The Harbor Press, 1938; The Comedy of Dante Alighieri, Florentine by birth but not in conduct; Part III, Heaven, American translation by Louis How, New York, The Harbor Press, I940.

I5 The Divine Comedy by Dante Alighieri; Inferno, Translated and edited by Thomas G. Bergin, New York, Appleton-Century, 1948; The Divine Comedy by Dante Alighieri; Purgatory, Translated and edited by Thomas G. Bergin, New York, Appleton-Century-Crofts, 1953; The Divine Comedy by Dante Alighieri; Paradise, Translated and edited by Thomas G. Bergin, New York, Appleton-Century-Crofts, I954.

I6 The Divine Comedy: The Inferno, Purgatorio, and Paradiso, a new translation into English blank verse by Lawrence Grant White, New York, Pantheon Books, I948.

I7 Dante, theologian: the Divine comedy, Translation and commentary by Patrick Cummins, St. Louis, B. Herder Book Co., 1948.

I8 The Inferno, Translated in verse by John Ciardi, Historical Introduction by A.T. MacAllister, Rutgers University Press, New Brunswick (New Jersey), 1954 (paperback edition: New York, New American Library, 1954); The Purgatorio, A Verse Translation for the Modern Reader, by John Ciardi, Introduction by Archibald T. MacAllister, New York, New American Library, 196r; The Paradiso, A verse rendering for the modern reader by John Ciardi, Introduction by John Freccero, New York, New American Library, 1970.

I9 John Ciardi, Translator's Note, in The Inferno, A verse rendering for the modern reader by John Ciardi, cit.

20 Ibidem.

2I For the following analysis I am indebted to that of William J. De Sua, Dante into English, cit., pp. III-II6. Dante Alighieri, The Divine Comedy, Inferno, Translated, with a Commentary by Charles S. Singleton, Princeton, Princeton University Press, 1970; Dante Alighieri, The Divine Comedy, Purgatorio, Translated, with a Commentary by Charles S. Singleton, Princeton, Princeton University Press, 1973; Dante Alighieri, The Divine Comedy, Paradiso, Translated, with a Commentary by Charles S. Singleton, Princeton, Princeton University Press, 1975.

23 Dante's Inferno, Translated with notes and commentary by Mark Musa, Bloomington and London, Indiana University Press, 1971; Dante's Purgatory, Translated with notes and commentary by Mark Musa, Illustrated by Richard M. Powers, Bloomington, Indiana University Press, I98I; Dante's 
Paradise, Translated with notes and commentary by Mark Musa, Bloomington, Indiana University Press, 1984.

24 Dante Alighieri, Inferno, translated with an introduction, notes, and commentary by Mark Musa, Harmondsworth, New York, Penguin Books, 1984; Dante Alighieri, Purgatory, translated with an introduction, notes, and commentary by Mark Musa, Harmondsworth, New York, Penguin Books, 1985; Dante Alighieri, Paradise, translated with an introduction, notes, and commentary by Mark Musa, Harmondsworth, New York, Penguin Books, 1986.

25 The Divine Comedy of Dante Alighieri, I. Inferno, A verse translation, with introduction and commentary, by Allen Mandelbaum, Drawings by Barry Moser, Berkeley-Los Angeles-London, University of California Press, 1980; The Divine Comedy of Dante Alighieri, II. Purgatorio, A verse translation, with introduction and commentary, by Allen Mandelbaum, Drawings by Barry Moser, Berkeley-Los Angeles-London, University of California Press, 1982; The Divine Comedy of Dante Alighieri, III. Paradiso, A verse translation, with introductions and commentary by Allen Mandelbaum, Drawings by Barry Moser, Berkeley-Los Angeles-London, University of California Press, 1984 .

26 The Inferno of Dante, A new verse translation by Robert Pinsky, Illustrated by Michael Mazur, With notes by Nicole Pinsky, Foreword by John Freccero, New York, Farrar Straus \& Giroux, 1994.

27 The Divine Comedy of Dante Alighieri. Inferno, Edited by Robert M. Durling and Ronald L. Martinez, New York, Oxford University Press, 1996. [The second volume of this translation had not yet been published when this article was written: The Divine Comedy of Dante Alighieri: Purgatorio, Edited and Translated by Robert M. Durling, Introduction and Notes by Ronald L. Martinez, Illustrations by Robert Turner, New York, Oxford University Press, 2003.]

28 The Divine Comedy of Dante Alighieri. Inferno, Edited by Robert M. Durling and Ronald L. Martinez, cit., p. 34 .

\section{Notes Robert Hollander, Translating Dante into English Again and Again}

I What follows is a slightly revised version of a talk presented at a plenary session on literary translation of the Medieval Academy of America, New York, 5 April 2002.

2 We are currently working on Paradiso. Our Inferno and Purgatorio have been published by Doubleday in 2000 and 2003, respectively.

3 John Ahern, Translations in English, in The Dante Encyclopedia, edited by Richard Lansing, Garland, 2000, pp. 824-830.

4 Charles Rogers, The Inferno of Dante Translated, London, J. Nichols, I782; Henry Boyd, A Translation of the Inferno of Dante Alighieri, London, C. Dilly, 2 vols., I785.

5 The Inferno of Dante Alighieri: canto I-XXXIV, With a Translation in English Blank Verse, Notes, and a Life of the Author, London, J. Carpenter, 2 vols., I805-1806; The Vision: or, Hell, Purgatory, and Paradise, of Dante Alighieri, Translated by the Rev. H.F. Cary, London, H. Frowde, I8I4.

6 Dante Alighieri, Inferno, Translated by Robert \& Jean Hollander, Introduction \& notes by Robert Hollander, New York, Doubleday, 2000; Dante Alighieri, Inferno, A New Verse Translation by Michael Palma, New York, W.W. Norton \& Company, 2002.

7 Dante Alighieri, The inferno, translated, edited, and with an introduction by Anthony Esolen, illustrations by Gustave Doré, New York, Modern Library, 2002.

8 Further bibliographical details can be found in the bibliography at the end of this volume.

9 Dante Alighieri, La commedia secondo l'antica vulgata, a cura di Giorgio Petrocchi, Milano, Mondadori, 4 vols., I966-1967.

IO Richard Wilbur's translation of Inferno 25 can be found in Daniel Halpern (ed.), Dante's Inferno. Translations by Twenty Contemporary Poets, Hopewell, Ecco Press, 1993, and was reprinted in Richard Wilbur, Mayflies. New Poems and Translations, New York, Hartcourt, Inc., 2000. 


\section{Notes Jean Hollander, 'Getting Just a Small Part of it Right'}

I The Inferno of Dante, A new verse translation by Robert Pinsky, Illustrated by Michael Mazur, With notes by Nicole Pinsky, Foreword by John Freccero, New York, Farrar Straus \& Giroux, 1994 .

2 Dante's Inferno, Translated with notes and commentary by Mark Musa, Bloomington and London, Indiana University Press, 1971. Penguin reprinted Musa’s translation in a popular paperback edition in 1984 .

3 The Divine Comedy of Dante Alighieri, 3 vols., Boston, Ticknor and Fields, I867: Longfellow's Inferno has been reprinted very recently: Dante Alighieri, Inferno, Translated by Henry Wadsworth Longfellow, Edited by Matthew Pearl, Introduction by Lino Pertile, New York, Modern Library, 2003.

\section{Notes Ronald de Rooy, The Poet Translated by American Poets}

I Dante's Il convivio (The Banquet), translated by Richard H. Lansing, New York \& London, Garland, I990, p. I8.

2 The twelve canticles are: James Torrens (1993, Paradiso), Steve Ellis (1994, Inferno, blank verse), Robert Pinsky (1994, Inferno; slant rhyme, terza rima), Peter Dale (1996, terza rima), Robert Durling and Ronald L. Martinez, (1996, Inferno, prose), Elio Zappula (1998, Inferno, blank verse), W.S. Merwin (2000, Purgatorio, blank verse), Robert and Jean Hollander (2000-2003, Inferno, Purgatorio, blank verse), Michael Palma (2002, Inferno, terza rima), Anthony Esolen (2002, Inferno, blank verse). Further bibliographical details can be found in the bibliography at the end of this volume.

3 Peter S. Hawkins and Rachel Jacoff (eds), The Poets' Dante. Twentieth-Century Responses, New York, Farrar Straus \& Giroux, 200I.

4 Daniel Halpern (ed.), Dante's Inferno. Translations by Twenty Contemporary Poets, Hopewell, Ecco Press, 1993.

5 Robert Pinsky, The Inferno of Dante. A new verse translation by Robert Pinsky. Illustrated by Michael Mazur. With notes by Nicole Pinsky. Foreword by John Freccero, New York, Farrar Straus \& Giroux, 1994.

6 Dante Alighieri, The Divine Comedy: Hell, Purgatory, Heaven, A Terza Rima Version by Peter Dale, London, Anvil, 1996.

7 «Agenda», Vol. 34, 3-4, autumn-winter 1996/1997.

8 Dante Alighieri, Purgatorio, A New Verse Translation by W.S. Merwin, New York, Alfred A. Knopf, 2000.

9 Dante Alighieri, Inferno. Translated by Robert \& Jean Hollander. Introduction \& notes by Robert Hollander, New York, Doubleday, 2000.

Io Dante Alighieri, Inferno, A New Verse Translation by Michael Palma, New York, W.W. Norton \& Company, 2002.

II Dante Alighieri, Purgatorio, A Verse Translation by Jean Hollander \& Robert Hollander. Introduction \& notes by Robert Hollander, New York, Doubleday, 2003.

I2 James Merrill, Introduction, in Daniel Halpern (ed.) Dante's Inferno. Translations by Twenty Contemporary Poets, cit., pp. IX-XIII, pp. X-XI. The propulsive movement of terza rima is a feature which recurs often in critical appraisal of this meter. Cf. Jacqueline Osherow, She's Come Undone: An American Jew Looks at Dante, in The Poets' Dante, cit., pp. 265-276, p. 271: 'I don't know of another form that so propels a poem forward and I don't know another long poem that moves so swiftly. [...] Writing in terza rima, one gets to be discursive and lyric simultaneously; one gets to be both narrative and descriptive.'

I3 Cf. Clive Wilmer, Dante made plain. Sacrifices and successes in two centuries of translating "the acerb Florentine", in "Times Literary Supplement", 4875, 6 September 1996, pp. 3-4, p. 4: 'the wrong formal decision at the outset can wreck an entire version.' 
Theodore J. Cachey, Jr., L'odissea del Dante americano, in «Belfagor», 55:3, 327 (2000), pp. 328-35, p. 330. Cf. Dorothy Sayers, Introduction, in The Comedy of Dante Alighieri the Florentine. Cantica I Hell "L'Inferno", Translated by Dorothy L. Sayers, Harmondsworth, Penguin, I949, p. 56: 'Blank verse, with its insidious temptation to be literal at the expense of the verse, has little advantage over prose and, though easier to write badly, is far more difficult to write well; while the rhymed couplet, or any stanza-form other than Dante's own, involves the placing of stanza-breaks at places where he did not choose to place them. I agree, therefore, with Maurice Hewlett that, for the translator, the choice is "terza rima or nothing".' Sayers's assertion has recently been repeated by the Spanish translator Angel Crespo, who stood up firmly for his choice in favor of terza rima (Angel Crespo and Michael Perna, Translating Dante's Commedia: Terza Rima or Nothing, in The Divine Comedy and the Encyclopedia of Arts and Sciences, edited by Giuseppe Di Scipio and Aldo Scaglione, Amsterdam, Benjamins, I988, pp. 373-385.)

I6 T.S. Eliot, What Dante Means to Me, in To Criticize the Critic, London, Faber and Faber, 1965, pp. 125-135. Ibid., p. I28: 'English is less copiously provided with rhyming words than Italian; and those rhymes we have are in a way more emphatic. The rhyming words call too much attention to themselves: Italian is the one language known to me in which exact rhyme can always achieve its effect [...] without the risk of obtruding itself.'

I8 Ibidem.

I9 Ibid., p. I29.

20 Ibid., p. I28-I29.

2I Ibid., p. I29.

22 Ibidem

23 In fact, in the first half of the twentieth century, there is a conspicuous number of translations in terza rima: 16 out of 42 - that is to say almost 40 percent - of all English translations within the period 1900-1962 are in terza rima. Cf. William J. De Sua, Dante into English. A Study of the Translation of the Divine comedy in Britain and America, Chapel Hill, University of North Carolina Press, 1964.

24 Dante Alighieri, The Divine Comedy, Translated, with a Commentary by Charles S. Singleton, Princeton, Princeton University Press (Inferno, 1970; Purgatorio, 1973; Paradiso, 1975).

25 The Divine Comedy of Dante Alighieri. Inferno, Edited by Robert M. Durling and Ronald L. Martinez, New York, Oxford University Press, 1996; The Divine Comedy of Dante Alighieri: Purgatorio, Edited and Translated by Robert M. Durling, Introduction and Notes by Ronald L. Martinez, Illustrations by Robert Turner, New York, Oxford University Press, 2003.

26 Recently, blank verse has been adopted for example by Mark Musa (197I, 198I, 1984), Allen Mandelbaum (1980, 1982, 1984), C. H. Sisson (1980), Nicholas Kilmer (1985 [Inferno]), Tom Phillips (1985 [Inferno]), James Finn Cotter (1987), Steve Ellis (1994 [Inferno]), James Torrens (1993 [Paradiso]), Elio Zappula (1998 [Inferno]), W. S. Merwin (2000 [Purgatorio]), Robert and Jean Hollander (2000, 2003 [Inferno, Purgatorio]) and Anthony Esolen (2002 [Inferno]).

27 Adopted by the poet W.S. Merwin (2000 [Purgatorio]) and by Robert and Jean Hollander (2000-2003 [Inferno, Purgatorio]).

28 Actually, on the Internet I found one more recent Inferno translation in terza rima by Seth Zimmerman (cf. http://home.earthlink.net/-zimls/), who on this same website also dedicates an entire essay to the problem of translating terza rima: Triple-Rhyming in the Inferno. Is it worth the torture?

29 In the above-mentioned volume Dante's Inferno, edited by Daniel Halpern, we find a large variety of metrical and rhythmical solutions: 'Some of them perform astonishing feats of traditional versification. Others forgo signaling the tercets in favor of stressing the unbroken narrative length; yet another cleverly reshapes each tercet's density into a lighter, beeswax hexagon. A prevailing impulse is to relax the strict metrical hold upon meaning, while preserving the look of the original.' (James Merrill, Introduction, cit., p. XII) Furthermore, it is interesting that Seamus Heaney and Derek Walcott, just like Pier Paolo Pasolini in Italy, sometimes adopt personalized types of terza rima in their own poems. In the introduction to his own translation, Peter Dale also mentions several examples of modern English 
poems which bring back to life the Dantean meter. In fact, the obsession with terza rima surfaces in strange places: both Edward Thomas, The Ash Grove, and Robert Frost, Stopping by Woods on a Snowy Evening transform terza rima into a system of four-line stanzas 'by doubling up the first a rhyme to a couplet.' Acquainted with the Night is a sonnet in terza rima by Robert Frost, and also Allen Tate uses terza rima in the third section of The Swimmers and Other Selected Poems (1970); Archibald MacLeish, Conquistador (1932), is a long terza rima poem 'where he uses modern oblique and half-rhymes to accommodate the rhyme and tries to capture the Italian double-rhyme effect by frequently allowing his rhymes a light unrhyming last syllable.' More recently, a strong Dantean influence can be felt in Seamus Heaney's Ugolino (cf. Peter Dale, Introduction, in The Divine Comedy: Hell, Purgatory, Heaven: A Terza Rima Version by Peter Dale, cit., pp. IX-XxiII, p. xv).

30 Wilbur's translation of Inferno 25 can be found in Dante's Inferno. Translations by Twenty Contemporary Poets, cit., and was reprinted in Richard Wilbur, Mayflies. New Poems and Translations, New York, Hartcourt, Inc., 2000.

3I Peter Dale, Richard Wilbur in conversation with Peter Dale, BTL, 200o, excerpts of which can be found on http://www.interviews-with-poets.com/richard-wilbur/wilbur-extracts.html.

32 The expression was used by C.H. Sisson. Cf. Edward Hirsch, A Fresh Hell. Robert Pinsky offers a new translation of Dante's "Inferno", in "The New Yorker", 23.0I.1995, pp. 87-90, p. 88.

33 The Comedy of Dante Alighieri the Florentine. Cantica I Hell "L'Inferno". Translated by Dorothy L. Sayers, cit., p. 228.

34 Cf. Dante Alighieri, Inferno, Translated by Robert \& Jean Hollander, Introduction \& notes by Robert Hollander, New York, Doubleday, 200o, p. 434.

35 Cf. Theodore J. Cachey, Jr., The Inferno of Dante: A New Verse Translation, in «Lectura Dantis», I8-I9, Spring-Fall (1996), pp. I34-I38, pp. I34-5: 'Against the background of current prose and blank verse renderings, the sharper contours and greater speed of Pinsky's Inferno have a revelatory force. Indeed, the translation's narrative drive and readability are unsurpassed - even more pronounced than the original's.' With regard to its rhythm, Pinsky's translation presents by and large 'the greatest possible contrast to the regular iambic pentameter of the current English blank verse renderings.' (Ibid., p. 137)

36 Michael Palma, The Man I Pretend to Be. The Colloquies and Selected Poems of Guido Gozzano, Princeton, Princeton University Press, 198I.

37 Anthony Oldcorn also sees an analogy between the two discourses: 'This final discourse [i.e. Inf. 25, I4O-I], like Vanni Fucci's resentful brag in the previous canto, verbalizes the malicious aggressiveness that possesses the anti-citizens of this bolgia, when they are not its hapless and helpless victims' (Canto XXV: The Perverse Image, in Lectura Dantis. Inferno, edited by Allen Mandelbaum, Anthony Oldcorn and Charles Ross, Berkeley, London, University of California Press, I998, pp. 328-47, p. 332).

38 By the way, it is worth noticing that all four translations strangely enough use the past tense in translating the first tercet, while Dante uses only present tense.

39 Tibor Wlassics, Translation or Interpretation? Notes on Dante in English, in Dante: Summa Medievalis, edited by Charles Franco, Stony Brook, NY, Forum Italicum, 1995, pp. I-9.

40 Cf. Dante Alighieri, Inferno, Translated by Robert \& Jean Hollander, cit., p. 432-433, and Robert Hollander, 'Ad ira parea mosso': God's Voice in the Garden (Inf. XXIV, 69), in "Dante Studies», IOI, (1983), pp. 27-49.

4I Dante Alighieri, Commedia, Inferno, con il commento di Anna Maria Chiavacci Leonardi, Milano, Mondadori, 1991, p. 746.

42 Dante Alighieri, Commedia, Inferno, con il commento di Anna Maria Chiavacci Leonardi, cit., p. 755.

43 Dante Alighieri, La Divina Commedia, a cura di Umberto Bosco e Giovanni Reggio, Firenze, Le Monnier, 1979, p. 374.

44 Peter Dale, Richard Wilbur in conversation with Peter Dale, cit.

45 In Halpern's volume, however, the canto of Ulisse had already been claimed by W.S. Merwin: 'When Dan Halpern of Ecco Press was arranging for the Inferno to be translated by various hands, I eagerly chose Canto xxv from among those not yet spoken for by Seamus Heaney [i.e. Inf. I-3], Bill Merwin [i.e. Inf. 26-27], and other worthies' (Ibidem). 


\section{Notes Paul Van Heck, Ciò che potea la lingua nostra. One Hundred and More}

Years of Dante Translations into Dutch

I See nos. I6-I8 in the Tables.

2 Dante Alighieri, Het Gastmaal [The Banquet], tr. Frans and Kees van Dooren, Amsterdam, Ambo, 20oI; Dante Alighieri, Pleidooi voor de eigen taal [A Plea for the Mother Tongue]. De vulgari eloquentia, tr. Lodi Nauta, Groningen, Historische Uitgeverij, 2002.

3 Dante Alighieri, Mijn vrouwe draagt de liefde in haar ogen. Vierentwintig liefdesgedichten gekozen en vertaald door Ike Cialona [My Lady Bears Love in Her Eyes. Twenty-four Love Poems Chosen and Translated by I.C.], Amsterdam, Prometheus, 200I.

4 Frans van Dooren's translation of the Vita Nuova (1988) and Rob Brouwer's translation of the Monarchia (1993) were both reprinted in 200I.

5 Giovanni Boccaccio, Het leven van Dante [The Life of Dante], tr. Ike Cialona, Amsterdam, Athenaeum-Polak \& Van Gennep, 2002. An earlier translation of Boccaccio's Vita, by Bas Arnold, was published in 1987 , on the occasion of the $666^{\text {th }}$ anniversary of Dante's death.

6 I am referring in particular to the III pastel illustrations for the Commedia by Judy Hudig (Amsterdam, Wereldbibliotheek, 200I) and to the double CD La Divina Commedia Gregoriana (Mirasound 399325, 2000) by the Schola Cantorum Karolus Magnus. On this CD Gregorian Chants mentioned in the Commedia alternate with fragmentary readings of the original text.

7 On the subject, see at least J. Berg, Over den invloed van de Italiaansche letterkunde op de Nederlandsche gedurende de negentiende eeuw [On the Influence of Italian Literature on Dutch Literature during the Nineteenth Century], Amsterdam, Kruyt, I9I9, pp. II-2I; Dante Alighieri I32I-I92I. Omaggio dell'Olanda, Den Haag, I92I, esp. the bibliographical survey of J. Berg, Dante in Olanda: studio bibliografico, pp. 2I4-28; J.L. Cohen, Dante in de Nederlandsche letterkunde [Dante in Dutch Literature], Haarlem, N/V H.D. Tjeenk Willink \& Zoon, I929, esp. pp. 85-152; V. Lo Cascio - E. Peternolli, Bibliografia dantesca, in Miscellanea Dantesca edita dalla Società Dantesca nei Paesi Bassi nella ricorrenza del settimo centenario della nascita del Sommo Poeta, Utrecht-Antwerpen, Uitgeverij Het Spectrum, 1965, pp. 27I-84; G. Francescato, entry Olanda in the Enciclopedia Dantesca (vol. IV, 1973); P. van Heck, Le traduzioni dantesche in Neerlandese (1900-1989), in L'opera di Dante nel mondo. Edizioni e traduzioni nel Novecento, a cura di Enzo Esposito, Ravenna, Longo, 1992, pp. II5-23. It must be said, however, that the bibliographical information contained in these contributions is often imprecise and incomplete. The article of Jan H. Terlingen, Dante nei Paesi Bassi, in Dante nel mondo, a cura di V. Branca ed E. Caccia, Firenze, Olschki, 1965, pp. 318-55 (reprinted with some modifications and with another title - Profilo dell'interpretazione e della critica dantesca nell'area linguistica olandesein Miscellanea Dantesca, cit., pp. 9-58), is essentially a survey of Dutch Dante studies, which only incidentally touches upon the translations.

8 Complete translations of the Vita Nuova were published by Nico van Suchtelen (ca. 1915, I954 ), A.H.J. van Delft (I920), H.W.J.M. Keuls (I950 or I95I, I9643 [?]), and Frans van Dooren (I988, $200 I^{2}$ ); complete translations of the Monarchia by Jan Asser (I94O), M.R. Morraye (without date, but ca. 1990), and Rob Brouwer (1993, 2001²).

9 Another French translation, which dates back to I75I, remained manuscript.

Io This conclusion is based on the information given in the Enciclopedia dantesca. Brief mention should be made here of the old translation into Castilian attributed to Enrique de Villena (finished in I428), and of that into Catalan by Andreu Febrer (finished in I429).

II A fourth version of the first canticle, by J. Sterenborg (Groningen, I926) is mentioned in Peternolli's bibliography (Miscellanea dantesca, cit., p. 274), but it is not registered in Brinkman's Catalogue of Printed Books in the Netherlands nor in the NCC (Dutch Electronic Central Catalogue), and I have been unable to trace a copy of it. The numerous fragmentary translations of the Commedia are left out of this survey. Finally, it may be permitted to mention a translation of the first canticle into Afrikaans: Dante Alighieri, Die Goddellike Komedie. Die Hel. Afrikaanse vertaling met inleidings deur 
Delamaine A.H. du Toit, Kaapstad, Zebra Publikaties, 1990, 2 vols. (with thanks to Philiep Bossier, who drew my attention to this publication).

I2 The descriptions offered here correspond to the first edition in book form. Integral or partial publications in literary magazines prior to this edition, which have not been inventoried systematically, will be recorded occasionally in the course of this survey. Changes in content and form in subsequent editions have usually been left out.

I3 Cohen, Dante in de Nederlandsche letterkunde, cit., p. I05, asserts that the semi-anonymous author of no. 9, who signs the preface as 'M.C.L.' and who in the bibliographies is called M.C. Loman, was a woman. About her, almost nothing is known to me.

I4 For titles, places of publication and publishers' names, see the bibliography at the end of this volume.

Is It must be admitted, however, that in the case of some of the oldest translations it is not always wholly clear and certain whether the three canticles were published simultaneously or at three consecutive times.

I6 Of Dorés I36 engravings ( 76 for the Inferno, 42 for the Purgatorio, I8 for the Paradiso), II3 (53, 42, I8) were included in this edition.

I7 Ten Kate's version was published more or less simultaneously in a rather sumptuous, illustrated edition (a) and in a cheap edition (b). The illustrations were printed from the same plates that were used for Hacke van Mijnden's edition (see Ten Kate's letters to his publisher Sijthoff, and a letter by Hacke van Mijnden's publisher Kruseman to Sijthoff [6-5-1876], now preserved in the Leiden University Library).

I8 In a letter (preserved in the Leiden University Library) dated December 5, [I865], Hacke van Mijnden writes to his publisher: 'This business [the publication of the Inferno] will cost me a lot of money, but... I hope it will bring me some honor and fame, a legacy which will be worth more to my children than a couple of thousands of guilders.' The printing costs would amount to some 6000 guilders for each of the three volumes (cf. A.C. Kruseman, Bouwstoffen voor een geschiedenis van den Nederlandschen Boekhandel gedurende de halve eeuw I830-I880 [Elements for a History of Dutch Book Trade I830-I880], Amsterdam, P.N. van Kampen \& Zoon, I886-87, 2 vols.; vol. II, p. 48).

I9 Publication years drawn from other sources are placed between square brackets.

20 The data in this column are essentially drawn from (or checked in) Brinkman's Catalogue and the NCC. It is common knowledge that the information contained in the older sections of the Brinkman is not always complete or reliable; nevertheless, the data in the present table should be more or less exact.

2I Cf. Kruseman, Bouwstoffen voor een geschiedenis, cit., vol. II, p. 48, where the publisher makes also clear that his edition of Hacke van Mijnden's translation was intended to be a showpiece of Dutch printing art: 'This edition $[\ldots]$ was made $[\ldots]$ with the greatest possible care, in order to show what Dutch typography was capable of.'

22 These numbers are given on one of the preliminary pages of the third edition.

23 See F. de Glas, Nienwe lezers voor het goede boek: de Wereldbibliotheek en 'Ontwikkeling' / De Arbeiderspers voor 1940 [New Readers for Quality Books: the Wereldbibliotheek and 'Ontwikkeling' / De Arbeiderspers before 1940], Amsterdam, Wereldbibliotheek, 1989. This study, however, tells us almost nothing about the Dante edition mentioned.

24 I owe these figures to personal communications by the translators and (regarding Brouwer's translation) by the publisher, Evelyn de Regt.

25 Besides the one-volume edition of Van Dooren's translation, which was published first in hardcover and after a decade or so in paperback, in recent years separate cheap editions have appeared of the Inferno (Amsterdam, Flamingo, 2000, 20023), Purgatorio (200I) and Paradiso (2002). Finally, mention should be made of a one-off edition of only six cantos (Baarn-Antwerpen, Ambo-Kritak, 1996).

26 It should be mentioned, however, that Van Dooren's prose translation was preceded by an experimental rendering of Inferno 3 into quatrains of rhymed nine-syllable lines, with alternatingly masculine and feminine endings. This experiment was later included in his anthology Gepolijst albast. Acht eenwen Italiaanse poëzie [Polished Alabaster. Eight Centuries of Italian Poetry], Baarn, Ambo, 1994, pp. 67-73. 
Inf. $\mathrm{I}$, which contains 136 lines, is rendered in $\mathrm{I} 28 ; \operatorname{Inf} .2$ (I42) in only 92; Inf. 3 (136) in $\mathrm{I3O}$; Inf. 4 (I5I) in $\mathrm{I} 6 \mathrm{0}$; and so on.

28 Accordingly, Van Dooren seems to have used a printing of the first version of the Sapegno edition, whose text was indeed based on Vandelli's critical edition. Its second version, which was published in 1968, was already based on the new critical edition by Petrocchi.

29 Antonius Henricus Josephus van Delft (1876-1958), a Catholic priest, served the parish of SintAnthonis (near Boxmeer, in Brabant) for many years. On his Dante Interpretation and his numerous other Dante contributions, see Terlingen, Dante nei Paesi Bassi, cit., pp. 329-3I. His other publications include an interpretation of Vondel's Altaargeheimenissen [Secrets of the Altar] (1924) and some (sacred) theatre plays. A milder judgment on his interpretation of Dante (and Vondel) than is formulated here has been pronounced by the Catholic poet and critic Anton van Duinkerken: 'His style is indigestible due to its compactness; but his mind is surprisingly daring and original.' (Brabantse herinneringen [Brabant Memories], Utrecht-Antwerpen, Het Spectrum, 1964, p. 175). But even Van Duinkerken feels obliged to admit that Van Delft had sent his interpretation to the desert: 'Science didn't take it into consideration. No one ever refers to it.'

30 On the genesis of this translation (which was made between October I92I and July 1923), see M. Uyldert, Naar de voltooiing. Uit het leven van Albert Verwey [Towards Completion. Out of the Life of A.V.], vol. III, Amsterdam, De Lange, 1959, pp. I06-IO. For a rather authoritative review, see B.H. Molkenboer O.P., Verwey's Dantevertaling, in «De Beiaard» Io (1925), pp. 5-24. Though occasionally lavishing words of praise for a number of well-wrought passages, the reviewer politely but decidedly denounces the 'Icaric tendencies' of the interpreter, the 'rather cerebral' character of his version, and his approach as such, which inevitably makes that 'not Dante, but Mr. Verwey becomes the main thing' ['niet Dante, maar de heer Verwey wordt zodoende de hoofdzaak']. Subsequently, Verwey published a contribution on De rol van de verbeelding in Dante's Commedia [The Role of Imagery in D.'s C.], in «Handelingen van het Twaalfde Nederlandse Philologen-Congres», 1927, pp. 9-37, and an article in which he mainly expounded his ideas about translating Dante: Een blik op de Divina Commedia [A Look at the D.C.], in "Leiding» I (1930), pp. 273-300 (see Terlingen, Dante nei Paesi Bassi, cit., p. 334). The manuscript of Verwey's translation is preserved in the Amsterdam University Library.

3I The third volume, which appeared posthumously, remained without motto.

32 Both poems are by the Dante translator Ten Kate.

33 This edition was voted among the most carefully edited books of 1999 by the Stichting Collectieve Propaganda van het Nederlandse Boek [Foundation for the Collective Propaganda of the Dutch Book]. Albert Verwey (Amsterdam I865 - Noordwijk 1937), after having acquired considerable fame as a poet and literary critic, was appointed professor of Dutch literature at Leiden University in 1924, at the age of nearly sixty, but he did not have academic roots and was largely autodidactic.

Culemborg, Blom \& Olivierse, I898-99, 2 vols.

36 For his Dante publications, see the cit. survey of J. Berg.

37 On Kok, see his interesting and eloquent Autobiografische aanteekeningen [Autobiographical Annotations] (1914, with a survey of his principal publications), published after his decease in the «Levensberichten van de Maatschappij der Nederlandsche Letterkunde». Interesting information about the genesis of his Dante translation is to be found in Kok's correspondence with his publisher, A.C. Kruseman, which is preserved in the Leiden University Library. On Kok's Shakespeare translations, see Robert H. Leek, Shakespeare in Nederland, Zutphen, De Walburg Pers, 1988, esp. pp. 78-8I, 83-85, II3-I4; on p. 8I our translator is called 'a very gifted man, who paired a real talent with a superior and for his times very modern insight into Shakespeare's mind and art' ['een zeer begaafd man, die wezenlijk talent paarde aan een superieur en, voor zijn tijd, zeer modern inzicht in Shakespeares geest en kunst'].

38 On Hacke van Mijnden, see the obituary in the "Levensberichten van de Maatschappij der Nederlandsche Letterkunde» (I873-75) by his son-in-law G. van Tienhoven, an Italian version of 
which (Un Dantista olandese. Cenni biografici) was published in 1873 in the "Rivista Europea». Interesting information about the genesis of his Dante translation is to be found in Hacke van Mijnden's correspondence with his publisher, A.C. Kruseman, which is preserved in the Leiden University Library.

39 In the foreword to Thoden van Velzen's Purgatorio it says: 'Dante is justly called the prophet of the Reformation. Already two centuries before Luther and Zwingli, in his immortal poem he strongly raised his voice against the Papacy, which made all Christianity stray from the track of truth and justice, transforming it into a monster, as John had described in his Apocalypse [I7, I-3; cf. Inf. I9, IO6-II]. In vivid colors he depicts the sad fruits of papal supremacy, to which he principally ascribes Christianity's decay. What he had experienced in his own environment and what he beheld in his mind's eye with regard to the future of the Church, we now see confirmed in our days. The whole of south-west Europe and Belgium, to which we are so closely connected, demonstrates how, under the pressure of Ultramontanism, entire nations fall into a superstition which degrades them to infantile children, or into disbelief, because knowing no other form of religion than the Roman-Catholic, they learn to mock and to despise any other religion. Hence, the decay of Spain, France and many other nations that once were so powerful [...].' In this context, it may be remembered that the first known (fragmentary) translations from Dante's work into Dutch are contained in the Dutch edition (Hoorn, Marten Gerbrantsz, 1632-33) of one of the most famous anti-papal and anti-Catholic publications of earlymodern times: the Catalogus testium veritatis by Mathias Flaccus Illyricus (cf. M. Roddewig, Die erste Niederländische Übersetzung aus dem Werk Dantes vom Jahr I633, in «Tijdschrift voor Nederlands en Afrikaans» I.2 (1983), pp. 50-60).

40 On Ten Kate, see his obituary (by E. Laurillard) in the «Levensberichten van de Maatschappij der Nederlandsche Letterkunde» (I890), pp. III-44 (with ample bibliography).

4I See the "Algemeen Letterlievend Maandschrift» n.s., 2 (Mengelwerk), pp. 467-72.

42 These first ten cantos were firstly published, as far as I know, in De Dichtwerken van [The Poetical Works of ] J.J.L. ten Kate, Leiden, Sijthoff, I86I-66, 8 vols.; vol. V (I864), pp. 136-94 (on p. 194 the date 'Sept. 1847').

43 See for instance Ten Kate's letter to Hacke van Mijnden, dated IO-2-I866, and preserved in the Leiden University Library. The judgment he formulates in this letter on the Inferno version is very favorable: 'The more I read your translation, the more excellent it appears to me.'

44 'Had Dr. Hacke's meritorious translation of the entire Divina Commedia been made publicly available, perhaps my Inferno would have remained fragmentary. But now I thought it could be useful not to withhold from the reading public of our fatherland my complete version of Hell.' In the introduction, there is no hint to a possible translation of the other two canticles, which clearly was never in Ten Kate's intentions.

45 See the correspondence between Ten Kate and his publisher Sijthoff, preserved in the Leiden University Library.

46 Bohl launched his attack with an article entitled $A$ cripple Dante, in which he blamed his rival for having rendered Dante's feminine rhyme with alternatingly masculine and feminine rhyme, and accused him of basing his translation on German translations rather than on the original text. In his reply, Ten Kate defended his metrical choice, admitting to having consulted in a distant past 'not infrequently' translations like those by Kannegiesser and Streckfuss, and more recently 'in cases of uncertainty' Longfellow's version ('And why not?'), and finally listing a long series of supposed mistranslations by his colleague. This reply provoked a verbose and frankly presumptuous reaction by Bohl (Dante criple at both sides), in which he continuously stressed Ten Kate's insufficient (and his own supposedly thorough) knowledge of the Italian language. The controversy was published in the last months of 1876 by «De Kunstbode», a periodical owned by the same publisher that brought out Bohl's Inferno. Cf. also Berg, Over den invloed van de Italiaansche letterkunde, cit., pp. I2-I3.

47 To my knowledge, the only other literary publication by Haghebaert is a translation 'into Flemish' of the Book of Job and the Small Prophets (I896-97). 
48 On Rensburg's esoteric Dante interpretation, see Terlingen, Dante nei Paesi Bassi, cit., pp. 324-25. Of his other publications, it will suffice in this context to mention his translation of Marx's On the Jewish Question (1908) and his own Theorie der evolutie: van oerschrift en oertaal tot wereldschrift en wereldtaal [Theory of Evolution: from Protowriting and Protolanguage to World Writing and World Language] (I93I). Rensburg died in Nazi captivity. On Rensburg, see the short monograph by Jaap Meijer, J.K. Rensburg, I870-1943: een joodse graalzoeker [A Jew in Quest of the Grail], Amsterdam, De Engelbewaarder, I98I.

49 Before appearing in book form, however, the translation had already been published in the periodicals «De Nieuwe Gids» (I898-1900) and "De XXste Eeuw» (1904-08). Of Boeken's other translational activities I should mention at least his version of Apuleius' The golden ass ([I898]-I90I), which was a byproduct of his PhD Thesis (Adnotationes ad Apuleii Metamorphoseon librum XI, I899), and his assistance with H.M. Boissevain's translation of Thucydides (1914-24). Boeken also wrote about Carducci and D'Annunzio. On his global interpretation of the Commedia, see Terlingen, Dante nei Paesi Bassi, cit., pp. 323-24. On the tragic private life of this amiable personality, see Max Nord's article in «Vrij Nederland», 7-5-1983 (Books Supplement).

50 From fl. 43 to fl. Is for the three volumes: see Brinkman, catalogue I93I-I935.

5I Those reasons may have been simply economic: translations from the Italian were indeed very few in the first postwar years, and Bremer's Dante translation was already available.

52 Kops had used the so-called 'spelling Kollewijn', which was never to gain an official status. Evidence of this aberrant orthography shows itself immediately in the title of this version, De Goddelike Komedie: the $i j$ in the ending of adjectives like goddelijk was reduced to $i$.

53 'In this new edition we have tried to correct and to complete Kops' first translation with the second whenever this seemed advisable, in order to offer in this way the best of his two translations.' (Introduction, p. 14). About this irresponsible way of text editing, I have already made some critical observations in the margin of a review of Van Dooren's translation (P.v.H., Een nieuwe Dante vertaling [A New Dante Translation], in «De Gids» I52 (1989), pp. 9II-I8; see note 5). In the editions of Kops' translation that have been published since then, Wijdeveld's account of his editing procedure has been suppressed.

54 This editorial fortune was undoubtedly favored by the fact that this translation remained for almost half a century the only verse translation available on the Dutch market.

55 At my request, the editor let me know he had returned Kops' manuscript to the Antwerp publisher; the publisher in his turn told me that the manuscript was no longer in his archive, and that it probably had been returned to the Franciscan order. An inquiry in the central archive of the order in Utrecht, however, did not produce any results either.

56 Father Voorvelt (who published, among other things, a translation of the Fioretti di San Francesco) died in 1997, on the feast of Saint Francis.

57 At the time, both men lived in separate monasteries, and Kops used to send his fellow brother the new text piece by piece, in order to get comments and suggestions. From time to time, moreover, the two used to meet to discuss problematical passages personally.

58 Father Kops was the author of countless articles in numerous Catholic periodicals, and in periodicals on Dutch language and culture. In 1938, he was appointed editor of a rather ambitious project: a very large anthological survey of Catholic literature from the Gospels down to the present, to be published under the title De Heerlijkheid der Kerke [The Glory of the Church]. Due to various causes, however, this work was never published. Kops had at his disposition a nice collection of Dantesca.

59 In the opening lines of the introduction to his translation, Kops immediately defines the Commedia as 'the world poem of Catholicism' ['het werelddicht van het Katholicisme']. This definition is explained with a rhetorical question: 'For what else is the Divina Commedia than the poetical elaboration and development of the thirteenth-century Catholic view of the world and of life in all its magnitude and fullness?' Dante's love for Beatrice forms a serious problem for him: 'How could the poet of the Divina Commedia continue to love the dead Beatrice, given the fact that some time after her death 
he entered into a marriage out of which various children were born? From a fundamentally Catholic point of view, indeed, Catholic marriage is not just a sacrament, but something so high and holy that the Apostle could say: "Husbands, love your wives as Christ loves the Church!" [Ephes. 5, 25].' For this fundamental question Kops sees no other possible explanation (or justification) than 'that Dante's love - which initially might have been even less than Platonic - as years went by, became evermore pure, evermore spiritual, evermore celestial, so that all earthly love finally dissolved itself into this celestial love as into a superior unity, thus becoming the purest reflection of Dante's love for God'.

60 Kops was, for instance, a warm advocate of the modernization of Catholic literature along the lines of the so-called Eighties Movement, which had revolutionized Dutch literature at the end of the nineteenth century.

6I Punctuation differences have been ignored.

62 According to Wijdeveld, in fact, Kops 'started to translate the Divina Commedia from scratch', and the new version is not a revised one, but a 'second translation'. Moreover, Wijdeveld declares to have transcribed only those fragments of the new translation that almost everyone would prefer to the corresponding elements in the old.

63 About this translator, almost nothing is known to me. Her version of the Commedia appears to have been her only publication in book form.

64 The Dante edition of Frederica Bremer (I88I-I963) was, as she tells us in her preface, based upon lectures and annotations by Wilhelmina Kuenen, for whom she felt a respect that verged on worship. Kuenen, who never published anything about Dante, was in her turn a close friend of the renowned Dante scholar and translator Philip H. Wicksteed (I844-1927). Bremer's other publications include a very successful and frequently reprinted Inleiding tot de kunstgeschiedenis [Introduction to Art History] (1927) and Het land dat Dante zag. Inleiding tot de middeleeuwse kunst in Italie [The Country Dante Saw. An Introduction to Medieval Italian Art] (1950).

65 Frans van Dooren (1934-) studied classical literature and subsequently Italian language and literature at the Catholic University of Nijmegen. During his entire working career, he taught Latin and Greek at the Titus Brandsma Lyceum in Oss. Van Dooren is undoubtedly the most prolific translator of (classical) Italian literature the Dutch-speaking regions have ever had. The long list of his publications include integral translations of Machiavelli's Il Principe (1976) and La Mandragola (1986), Leopardi's Pensieri (1977), Dante's Vita Nuova (1986) and Convivio (2001, in collaboration with his son Kees), and Leopardi's Canti (199I); selected poetry of Petrarch (1979), Luzi (1982), Angiolieri (1986), Michelangelo (1986), Folgore da San Gimignano (1989), female poets of the Cinquecento (1992), D’Annunzio (1996); selected pages from Boccaccio's Decameron (198I), Petrarch's Epistolae (1998) and Leopardi's Zibaldone (200I). In 1994, he published an anthology of his poetical translations, entitled Gepolijst albast: acht eenwen Italiaanse poëzie [Polished Alabaster. Eight Centuries of Italian Poetry], and in 1999 a Geschiedenis van de klassieke Italiaanse literatuur [History of Classical Italian Literature] from its origins up to the $1^{\text {th }}$ century. Currently (March 2003), his translation of Tasso's Gerusalemme liberata is in press. In 1990, Frans van Dooren was awarded the 'Martinus Nijhoff prize', the most prestigious prize for literary translations in the Netherlands.

66 Jacques Janssen (1944-) studied sociology at the Catholic University of Nijmegen, where he actually holds the chair of Psychology of Culture and Religion. His recent scientific publications include Jeugdcultuur, een actuele geschiedenis [Youth Culture, a Current History] (Utrecht, De Tijdstroom, 1994), Nederland als religieuze proeftuin [The Netherlands as an Experimental Garden for Religion] (Nijmegen, KSGV, 1998) and Aan de onbekende God. Reiken naar religie in een geseculariseerde cultuur [To the Unknown God. Reaching for Religion in a Secularized Culture] (Amsterdam, SUN, 2002). In recent years, Jacques Janssen has been among the warmest Dutch advocates of Dante's work, which he brings to the attention of a broad public in many ways and often using various multimedial means.

67 Ike Cialona-Janszen studied Italian language and literature at Amsterdam University and qualified as an interpreter-translator in Italian. For many years, she worked as a translator and interpreter, for 
instance for Dutch radio and television. Since 199I, she has been active exclusively as a translator of (Italian) literature, especially poetry. Her publications include an integral translation, in the original's meter, of Ariosto's Orlando Furioso (1998); selected poetry of Saba (1995), Petrarch (1998), Dante (200I) and D'Annunzio (2002); and Boccaccio's Vita di Dante (2002). Peter Verstegen (1938-) studied history and translation science at the University of Amsterdam. Subsequently, he taught at the Amsterdam Institute of Translation Studies. In 1993, he defended his $\mathrm{PhD}$ thesis, entitled Vertaalkunde versus vertaalwetenschap [Translation Art versus Translation Science]. His numerous translations include authors like Nabokov, Baudelaire, Verlaine, Heine, Rilke, Shakespeare, Cummings, and Auden. He also published some original poetry. For his translational work, he was awarded the Martinus Nijhoff prize in 1973.

68 Rob Brouwer (1938-) graduated in classical literature. Subsequently, he taught the classics at the Amsterdam Vossius Gymnasium, and lectured on the Classical Tradition at the University of Utrecht. His publications include translations of Boethius's De consolatione philosophiae (1990, 2000²), Dante's Monarchia (1993, 20012) and Virgil's Bucolica (1995).

\section{Notes Pieter de Meijer, Translating Dante’s Translations}

I Dante Alighieri, Mijn komedie. Deel I: Hel, Vertaald, ingeleid en geannoteerd door Jacques Janssen, Nijmegen, Sun, 1999.

2 Dante Alighieri, De goddelijke komedie, Met alle prenten van Gustave Doré, Vertaald door Ike Cialona en Peter Verstegen, Amsterdam, Athenaeum-Polak \& Van Gennep, 200o; vol. I (translation), vol. 2 (Italian text and commentary).

3 Dante Alighieri, De goddelijke komedie. Deel I: Inferno, Vertaald door Rob Brouwer, Met een inleiding door Ronald de Rooy, Leiden, Primavera Pers, 20oo; Dante Alighieri, De goddelijke komedie. Deel II: Purgatorio, Vertaald door Rob Brouwer, Leiden, Primavera Pers, 20or; Dante Alighieri, De goddelijke komedie. Deel III: Paradiso, Vertaald door Rob Brouwer, Leiden, Primavera Pers, 2002.

4 Dante Alighieri, Het Gastmaal [The Banquet], Vertaald, ingeleid toegelicht door Frans van Dooren $\&$ Kees van Dooren, Amsterdam, Ambo, 200I.

5 Dante Alighieri, Pleidooi voor de Eigen Taal. De vulgari eloquentia [A Plea for the Mother Tongue. De Vulgari Eloquentia], Vertaald, ingeleid en van een nawoord voorzien door Lodi Nauta, Groningen, Historische Uitgeverij, 20or.

6 Wiel Logister, Dante dichter mysticus pelgrim. De spiritualiteit van de Divina Commedia [Dante Poet Mystic Pilgrim. Spirituality in the Divine Comedy], Averbode, Gooi en Sticht, 2000.

7 Giovanni Boccaccio, Het leven van Dante [The Life of Dante], Vertaald door Ike Cialona, Amsterdam, Athenaeum-Polak \& Van Gennep, 2002.

8 Toon Tellegen, Enkele Onwaarschijnlijke Aantekeningen van Dante Alighieri bij het Schrijven van zijn Goddelijke Komedie, Bergen, Februari Boekhandels, 2000.

9 Jacques Janssen, Voorwoord, in Dante Alighieri, Mijn komedie. Deel I: Hel, cit., p. 8: 'Mijn interesse voor Dante groeide, maar de gedachte zijn complexe werk te vertalen kwam nooit bij mij op. Ik ben gewoon begonnen, november 1994, in een impuls en uit ergernis. Ik begreep niet waarom de Divina Commedia, die ik altijd hóór als ik er in lees, in het Nederlands niet voor te lezen is en bovendien zoveel ingewikkelder en verhevener aandoet dan het origineel klinkt.'

Io Jacques Janssen, Inleiding, in Dante Alighieri, Mijn komedie. Deel I: Hel, cit., p. 26: 'Het vertalen van de Divina Commedia is een monnikenwerk, of eerder: een hels karwei.'

II Ibid., p. 30.

I2 Ibid., p. 26: 'Alle poëzie is per definitie onvertaalbaar, omdat het onmogelijk is de harmonie en de muziek die erin vervat zijn over te zetten in een andere taal. Daarom kunnen wij de schoonheid van de psalmen niet ervaren en is het maar beter Homerus onvertaald te laten.' In Richard Lansing's translation of the Convivio, this fragment runs as follows: 'Therefore everyone should know that 
nothing harmonized according to the rules of poetry can be translated from its native tongue into another without destroying all its sweetness and harmony. This is the reason why Homer has not been translated from Greek into Latin as have been other writings we have of theirs. And this is the reason why the verses of the Psalter lack the sweetness of music and harmony; for they were translated from Hebrew into Greek and from Greek into Latin, and in the first translation all their sweetness was lost.' (Dante's Il convivio (The Banquet), translated by Richard H. Lansing, New York \& London, Garland, I990, p. I8).

I3 Ibid., p. 4I: 'De christenmens moet een lange en ingewikkelde tocht ondernemen. Ik ga die tocht met Dante, en de complexiteit van de onderneming is me lief. Er groeit, en dat is het grote geheim van Dante, geleidelijk een hechte band tussen lezer en schrijver. [...] Hij ging zijn tocht, het is een tocht van alle tijden. Zijn Komedie is mijn komedie. Ik volg hem op de voet. Zwijgend lopen we als minderbroeders achter elkaar, de oudste voorop: "Tu sarai primo e io sarò secondo". Ik hoor de voetstappen, die het gedicht op gang brengen.'

I4 Osip Mandelstam, Conversation about Dante, in The Complete Critical Prose and Letters, Edited by Jane Gary Harris, Translated by Jane Gary Harris and Constance Link, Ann Arbor, Ardis, 1979, pp. 397-442; recently reprinted in Peter S. Hawkins and Rachel Jacoff (eds.), The Poets' Dante, New York, Farrar Straus \& Giroux, 200I, pp. 40-93.

I5 Dante Alighieri, De Goddelijke Komedie, vertaling in terzinen door Albert Verwey, Haarlem, Tjeenk Willink \& Zoon, I923.

I6 Ike Cialona and Peter Verstegen, Voorwoord, in Dante Alighieri, De goddelijke komedie, cit., p. 5.

I7 Ibidem ('In een poëtische vertaling gaat altijd een deel van de inhoud verloren').

I8 Ibidem ('wie nauwkeurig wil weten wat Dante zegt, zal vaak gebaat zijn met onze noten').

I9 Ibidem ('De Komedie is historisch, retorisch en compositorisch van een ongekende rijkdom; maar zij is bovenal een gedicht, een werk waarin de gedachten gedragen worden door de muziek van maat en rijm, ritme, alliteratie en assonantie').

20 Cf. note 3.

2I Rob Brouwer, Van de vertaler, in Dante Alighieri, De goddelijke komedie. Deel I: Inferno, Vertaald door Rob Brouwer, cit., p. 7: 'De met de Italiaanse tekst (van Petrocchi) a fronte hier gepresenteerde vertaling is er een in versregels, en wel afwisselend elf- en tienlettergrepige (hendecasyllabi en decasyllabi). Van het gefixeerde eindrijm is afgezien, maar allerlei vormen van binnenrijm, assonantie en allitteratie zijn toegelaten en te baat genomen bij alle gelegenheden waar dat zonder dwang kon.' Ibid., p. 8: 'Erika heeft met grote trouw en nauwgezetheid mijn eerste versies van elk canto portie voor portie gelezen: of het meteen begrijpelijk, of het mooi genoeg was en of de res metricae in orde waren.'

23 Massimiliano Chiamenti, Dante Alighieri Traduttore, Firenze, Le Lettere, 1995.

24 Peter Newmark, A Textbook of Translation, London, Prentice Hall Press, I988.

25 Dante Alighieri, De goddelijke komedie, cit., vol. 2, p. I87: 'De Latijnse citaten in de Divina Commedia zijn vernederlandst.'

26 'From your accent it becomes very clear that you were born in that noble fatherland to which I perhaps caused too much harm.'

27 'By your accent I recognize you as being Tuscan / born in the prominent hometown / to which perhaps I have done too much wrong.'

28 'Your speech betrays that you and me share / that noble fatherland to which I myself / perhaps caused too much mischief.'

29 'trusting in myself more than in another' (Dante's Il convivio (The Banquet), translated by Richard H. Lansing, cit., p. 24).

30 Dante Alighieri, Commedia, con il commento di Anna Maria Chiavacci Leonardi, Volume secondo, Purgatorio, Milano, Mondadori, 1994, p. 56.

3I Massimiliano Chiamenti, Dante Alighieri Traduttore, cit., p. 205.

32 Ibid., pp. 205-206. 
33 Ibid., p. 207.

34 Ibidem.

35 Ibid., p. 205.

36 'The first Golden Age will repeat itself / Justice will return to the earth / A new race will descend from heaven.'

37 'Like you once said in poetry: A new ordainment dawns, / Justice returns and the first Era, / And from heaven a new race descends.' 



\section{About the Contributors}

Monika Beisner was born in Hamburg. She studied painting in Braunschweig and Berlin. A German Academic Exchange Scholarship (1966-1967) and a Fulbright Grant (1968-1970) enabled her to continue her studies in London and New York. She went on to concentrate on children's books. More recently, she has also worked on books for adults. Her images have always been more than mere illustrations, her aim being to make image and text speak together and her guiding principle, that the pleasure of looking encourages careful reading. Monika Beisner paints in egg tempera, the technique of medieval book illustration. Historical and modern perspectives, reality and dream, imagination and precise observation, all combine in her work to create a visual language of great power and originality. In the 1970s, Monika Beisner gained her international reputation with books that were translated from their original German or English into Danish, Dutch, Finnish, French, Italian, Japanese, Catalan and Spanish. The illustrations in this volume appeared for the first time in 200I (Dante Alighieri, Die Göttliche Komödie, translation Karl Vossler, with Ioo illustrations by Monika Beisner, Leipzig, Faber \& Faber, 200I, reprinted in 2002 and Bertelsmann Club, 2002). Since 1999, Monika Beisner has been working on illustrations for Ovid's Metamorphoses.

Paolo Cherchi is professor of Italian and Spanish Literature at the University of Chicago and professor of Italian Literature at the Università di Ferrara. His research focuses mainly on Medieval and Renaissance literature. Some of his most important studies include Andrea Capellano, i trovatori e altri temi romanzi (Roma, Bulzoni, 1979), Capitoli di critica cervantina (Roma, Bulzoni, 1977), Andreas and the Ambiguity of Courtly Love (Toronto, University of Toronto Press, 1994), La metamorfosi dell'Adone (Ravenna, Longo, 1996), Polimatia di riuso: mezzo secolo di plagio I539-1589 (Roma, Bulzoni, 1998), and Ricerche sulle selve rinascimentali (Ravenna, Longo, 1999). Furthermore, Paolo Cherchi edited Tomaso Garzoni's Opere (Ravenna, Longo, 1993) and his La piazza universale di tutte le professioni del mondo (Torino, Einaudi, 1996). A recent collection of essays, L'alambicco in biblioteca: distillati rari (Ravenna, Longo, 2000), shows Cherchi's wide range of scientific and literary interests. He recently received the Special Jury Award of the Premio Letterario Dessi for his work of fiction Herostraticon - Medaglioni di astripeti ovvero dall'osco-umbro al logudorese (Sassari, Editrice democratica sarda, 2000).

Paul van Heck is senior lecturer of Italian Literature at the University of Leiden. He has published a critical edition of Carducci's first Odi barbare (Leiden, 1988), after which his research has concentrated above all on the works of Niccolò Machiavelli. He has edited and translated several of Machiavelli's works into Dutch, for example Discorsi sopra la prima deca di Tito Livio (Discorsi: gedachten over staat en politiek, Amsterdam, Ambo, 1997) and La Vita di Castruccio Castracani (Het leven van Castruccio Castracani, Baarn, Ambo, 1993).

Jean Hollander is a poet and a teacher of literature and creative writing at Princeton University, Brooklyn College, Columbia University, and Rider University. She is the director of the Writers' Conference at the College of New Jersey. Her first book of poetry, Crushed into honey (Upper Montclair, Saturday Press, 1986), won the Eileen W. Barnes award. Her poems and essays have been published in numerous journals like The Sewanee Review, The American Scholar, and The Literary Review. She has translated poems by Hugo von Hofmannsthal (The woman without a shadow, Lewiston, Edwin Mellen, 1993), and, together with her husband, Robert Hollander, she is working on a free verse translation of Dante's Comedy. Doubleday has published their Inferno (New York, 2000) and Purgatorio (New York, 2003).

Robert Hollander is professor of European Literature at Princeton University. He has published a dozen books and seventy-five articles on Dante, Boccaccio and other Italian authors. Among his most recent 
publications are Boccaccio's Dante and the Shaping Force of Satire (Ann Arbor, The University of Michigan Press, 1997) and Dante: A Life in Works (New Haven, Yale University Press, 200I). Together with his wife, the poet Jean Hollander, he is currently translating Dante's Comedy, of which Inferno (New York, Doubleday, 2000) and Purgatorio (New York, Doubleday, 2003) have been published. Hollander has received many awards for his scholarly work: in 1988 he received the gold medal for his studies on Dante from the City of Florence, and in 1997 he was made honorary citizen of Certaldo. He is also the founder and director of two important websites dedicated to Dante: the Princeton Dante Project (http://www. princeton.edu/ -dante) and the invaluable Dartmouth Dante Project, a database containing 65 Latin, English and Italian commentaries on Dante's Comedy (for Internet access use: http://dciswww.dartmouth.edu:50080/?\&\&\&7\&s, for a Telnet connection use telnet://ddp.dartmouth.edu).

Pieter de Meijer is emeritus professor of Italian Literature at the University of Amsterdam. He has published studies and articles on many classical and modern Italian authors. In particular, he has focused his attention on Giovanni Verga (Costanti del mondo verghiano, Salvatore Sciascia, Roma, 1969), Ludovico Ariosto, Edoardo Sanguineti, Dante and Boccaccio. De Meijer has also published several studies on narratology (cf. La narrativa italiana dalle origini ai giorni nostri, Torino, Einaudi, 1997), on the theory of literary genres, and on problems related to the history of literature. During the last eight years of his academic career, De Meijer was rector of the University of Amsterdam, after which he became the chairman of the Dutch UNESCO committee.

Ronald de Rooy is lecturer of Italian Literature at the University of Amsterdam. He has published a study on narrative elements in modernist Italian poetry (Il narrativo nella poesia moderna, Firenze, Cesati, 1997) and various articles on Dante, Montale, Caproni and other Italian authors. Forthcoming is a study on Dante's reception by late-twentieth-century Italian and Anglo-American poets like Giorgio Caproni, Edoardo Sanguineti, Mario Luzi, Giovanni Giudici, Seamus Heaney and Derek Walcott ( Il poeta che parla ai poeti», Firenze, Cesati, 2003). 


\section{Selected Bibliography of American and English Dante translations}

A complete bibliography of Anglo-American Dante translations up to 1962 can be found in William J. De Sua, Dante into English. A study of the translation of the Divine comedy in Britain and America, Chapel Hill, University of North Carolina Press, 1964, pp. I27-I32. Valuable information on Anglo-American translations from the period $1953-2000$ is to be found in the online American Dante Bibliography (http://www.brandeis.edu/library/dante/). In the following selected bibliography are listed chronologically only those American and English translations which are mentioned or discussed in the course of this volume.

\section{Charles Rogers [1782]}

- The Inferno of Dante Translated, London, J. Nichols, 1782.

Henry Boyd [1785]

- A translation of the Inferno of Dante Alighieri, London, C. Dilly, 1785.

Henry Francis Cary [1805-1806, 1814]

- The Inferno of Dante Alighieri: canto I-XXXIV, With a Translation in English Blank Verse, Notes, and a Life of the Author, London, J. Carpenter, 2 vols., I805-1806.

- The Vision: or, Hell, Purgatory, and Paradise, of Dante Alighieri, Translated by the Rev. H.F. Cary, London, H. Frowde, I8I4.

Thomas William Parsons [1843, 1867, 1875, 1893]

- The First Ten Cantos of the Inferno of Dante Alighieri, Boston, William D. Tickner, I843.

- The First Canticle of the Divine Comedy of Dante Alighieri, Boston, De Vries, Ibarra, I867.

- The Ante-Purgatorio of Dante Alighieri, Cambridge, Massachusetts, J. Wilson and Son, I875.

- The Divine Comedy of Dante Alighieri, Translated into English verse by Thomas William Parsons, With a Preface by Charles Eliot Norton and a Memorial Sketch by Louise Imogen Guiney, Boston and New York, Houghton, Mifflin and Company, I893.

Henry Wadsworth Longfellow [1867]

- The Divine Comedy of Dante Alighieri, 3 vols., Boston, Ticknor and Fields, I867.

Charles Eliot Norton [1891-1892]

- The Divine Comedy of Dante Alighieri, Vol. I. Hell, Boston and New York, Houghton Mifflin and Company, I89I.

- The Divine Comedy of Dante Alighieri, Vol. II. Purgatory, Boston and New York, Houghton Mifflin and Company, 1892 .

- The Divine Comedy of Dante Alighieri, Vol. III. Paradise, Boston and New York, Houghton Mifflin and Company, 1892.

John Carlyle, Philip Wicksteed, Thomas Okey [1899-190I]

- The Inferno of Dante Alighieri, London, J.M. Dent (The Temple Classics), 1900. This famous Temple Classics edition of the Inferno was edited by Herman Oelsner, while the translation was reprinted, with certain alterations, from John Carlyle's (John Aitken Carlyle, Dante's Divine comedy: The Inferno, A Literal Prose Translation With The Text of The Original Collated From The Best Editions and Explanatory Notes, London, Chapman, I849).

- Thomas Okey, The Purgatorio of Dante Alighieri, London, J.M. Dent (The Temple Classics), I90I.

- Philip Henry Wicksteed, The Paradiso of Dante Alighieri, London, J.M. Dent (The Temple Classics), I899. 


\section{Marvin Richardson Vincent [1904]}

- The Divine Comedy of Dante; The Inferno, New York, Charles Scribner's Sons, 1904.

\section{Henry Johnson [1915]}

- La Commedia di Dante Alighieri; The Divine Comedy, translated by Henry Johnson, New Haven, Yale University Press, I9I5.

Courtney Langdon [1918, 1920, 1921]

- The Divine Comedy of Dante Alighieri; Vol. I. Inferno, the Italian text with a translation in English blank verse and a commentary by Courtney Langdon, Cambridge, Mass., and London, Harvard University Press, I918.

- The Divine Comedy of Dante Alighieri; Vol. II. Purgatorio, the Italian text with a translation in English blank verse and a commentary by Courtney Langdon, Cambridge, Mass., and London, Harvard University Press, 1920.

- The Divine Comedy of Dante Alighieri; Vol. III. Paradiso, the Italian text with a translation in English blank verse and a commentary by Courtney Langdon, Cambridge, Mass., and London, Harvard University Press, I92I.

\section{Jefferson Butler Fletcher [1933]}

- The Divine Comedy of Dante Alighieri, translated by Jefferson Butler Fletcher, New York, MacMillan, 1933.

\section{Laurence Binyon [1933, 1938, 1943]}

- Dante's Inferno, With a translation into English triple rhyme by Laurence Binyon London, Macmillian and co., limited, 1933.

- Dante's Purgatorio, With a translation into English triple rhyme by Laurence Binyon, London, Macmillian and co., limited, 1938.

- Dante's Paradiso, With a translation into English triple rhyme by Laurence Binyon, London, Macmillian and co., 1943.

Louis How [1934, 1937, 1940]

- Here beginneth the Comedy of Dante Alighieri, Florentine by birth but not by conduct; Part I, Hell, American translation by Louis How, New York, The Harbor Press, 1934.

- The Comedy of Dante Alighieri, Florentine by birth but not in conduct; Part II, Purgatory, American translation by Louis How, New York, The Harbor Press, 1938.

- The Comedy of Dante Alighieri, Florentine by birth but not in conduct; Part III, Heaven, American translation by Louis How, New York, The Harbor Press, 1940.

John Sinclair [1939, 1946]

- The Divine Comedy of Dante Alighieri, with translation and comment by John D. Sinclair, Inferno, New York, Oxford University Press, 1939.

- The Divine Comedy of Dante Alighieri, with translation and comment by John D. Sinclair, 3 vols., London, John Lane, 1946.

\section{Lawrence Grant White [1948]}

- The Divine Comedy: The Inferno, Purgatorio, and Paradiso, a new translation into English blank verse by Lawrence Grant White, New York, Pantheon Books, 1948.

\section{Patrick Cummins [1948]}

- Dante, theologian: the Divine comedy, Translation and commentary by Patrick Cummins, St. Louis, B. Herder Book Co., 1948.

\section{Dorothy Leigh Sayers [1949, 1955, 1962]}

- The Comedy of Dante Alighieri The Florentine, Cantica I Hell "L'Inferno", Translated by Dorothy L. Sayers, Harmondsworth, Penguin Books, 1949. 
- The Comedy of Dante Alighieri The Florentine, Cantica II Purgatory, "Il Purgatorio», Translated by Dorothy L. Sayers, Harmondsworth, Penguin Books, 1955.

- The Comedy of Dante Alighieri The Florentine, Cantica III Paradise, "Il Paradiso", Translated by Dorothy L. Sayers and Barbara Reynolds, Harmondsworth, Penguin Books, I962.

Thomas Goddard Bergin [1948, 1953, 1954]

- The Divine Comedy by Dante Alighieri; Inferno, Translated and edited by Thomas G. Bergin, New York, Appleton-Century, 1948.

- The Divine Comedy by Dante Alighieri; Purgatory, Translated and edited by Thomas G. Bergin, New York, Appleton-Century-Crofts, 1953 .

- The Divine Comedy by Dante Alighieri; Paradise, Translated and edited by Thomas G. Bergin, New York, Appleton-Century-Crofts, 1954.

John Ciardi [1954, 1961, 1970]

- The Inferno, Translated in verse by John Ciardi, Historical Introduction by A.T. MacAllister, Rutgers University Press, New Brunswick (New Jersey), 1954 (paper-back edition: New York, New American Library, 1954)

- The Purgatorio, A Verse Translation for the Modern Reader, by John Ciardi, Introduction by Archibald T. MacAllister, New York, New American Library, I96I.

- The Paradiso, A verse rendering for the modern reader by John Ciardi, Introduction by John Freccero, New York, New American Library, 1970.

Geoffrey Langdale Bickersteth [1932, 1955]

- The Paradiso of Dante Alighieri, with a translation into English triple rhyme and a brief introduction by Geoffrey L. Bickersteth, Cambridge, Cambridge University Press, 1932.

- The Divine Comedy of Dante Alighieri, translated from the Italian into English triple rhyme by Geoffrey L. Bickersteth, Aberdeen, Aberdeen University Press, I955.

Charles Singleton [1970, 1973, 1975]

- Dante Alighieri, The Divine Comedy, Inferno, Translated, with a Commentary by Charles S. Singleton, Princeton, Princeton University Press, 1970

- Dante Alighieri, The Divine Comedy, Purgatorio, Translated, with a Commentary by Charles S. Singleton, Princeton, Princeton University Press, 1973

- Dante Alighieri, The Divine Comedy, Paradiso, Translated, with a Commentary by Charles S. Singleton, Princeton, Princeton University Press, 1975

Mark Musa [1971, 198I, 1984]

- Dante's Inferno, Translated with notes and commentary by Mark Musa, Bloomington and London, Indiana University Press, 1971.

- Dante's Purgatory, Translated with notes and commentary by Mark Musa, Illustrated by Richard M. Powers, Bloomington, Indiana University Press, 198I.

- Dante's Paradise, Translated with notes and commentary by Mark Musa, Bloomington, Indiana University Press, 1984.

- Dante Alighieri, Inferno, translated with an introduction, notes, and commentary by Mark Musa, Harmondsworth, New York, Penguin Books, 1984.

- Dante Alighieri, Purgatory, translated with an introduction, notes, and commentary by Mark Musa, Harmondsworth, New York, Penguin Books, 1985.

- Dante Alighieri, Paradise, translated with an introduction, notes, and commentary by Mark Musa, Harmondsworth, New York, Penguin Books, 1986.

Allen Mandelbaum [1980, 1982, 1984]

- The Divine Comedy of Dante Alighieri, I. Inferno, A verse translation, with introduction and commentary, by Allen Mandelbaum, Drawings by Barry Moser, Berkeley-Los Angeles-London, University of California Press, I980. 
- The Divine Comedy of Dante Alighieri, II. Purgatorio, A verse translation, with introduction and commentary, by Allen Mandelbaum, Drawings by Barry Moser, Berkeley-Los Angeles-London, University of California Press, 1982.

- The Divine Comedy of Dante Alighieri, III. Paradiso, A verse translation, with introductions and commentary by Allen Mandelbaum, Drawings by Barry Moser, Berkeley-Los Angeles-London, University of California Press, 1984 .

C.H. Sisson [1980, 198I]

- The Divine Comedy, A new translation by C.H. Sisson, Manchester, Carcanet New Press Limited, 1980

- The Divine Comedy, A new translation by C.H. Sisson, Introduction, Commentary, Notes and Bibliography by David H. Higgins, Chicago, Regnery Gateway, 198I.

Nicholas Kilmer [1985]

- The Inferno, Translated by Nicholas Kilmer, Illustrated by Benjamin Martinez, Brookline Village, Massachusetts, Branden Publishing Co., I985.

\section{Tom Phillips [1985]}

- Dante's Inferno: The First Part of the Divine Comedy of Dante Alighieri, Translated and Illustrated by Tom Phillips, London and New York, Thames and Hudson, 1985.

\section{James Finn Cotter [1987]}

- The Divine Comedy, A New Translation and Introduction by James Finn Cotter, With the complete illustrations by William Blake, Amity, NY, Amity House, 1987.

James Torrens [1993]

- Dantés Paradise, Translation and Commentary by James Torrens, Scranton, Pennsylvania, University of Scranton Press, 1993.

Steve Ellis [1994]

- Inferno / Hell, translated, annotated, and introduced by Steve Ellis, London, Chatto \& Windus, 1994.

\section{Robert Pinsky [1994]}

- The Inferno of Dante, A new verse translation by Robert Pinsky, Illustrated by Michael Mazur, With notes by Nicole Pinsky, Foreword by John Freccero, New York, Farrar Straus \& Giroux, 1994.

Robert M. Durling [1996, 2003]

- The Divine Comedy of Dante Alighieri. Inferno, Edited by Robert M. Durling and Ronald L. Martinez, New York, Oxford University Press, 1996.

- The Divine Comedy of Dante Alighieri: Purgatorio, Edited and Translated by Robert M. Durling, Introduction and Notes by Ronald L. Martinez, Illustrations by Robert Turner, New York, Oxford University Press, 2003.

Peter Dale [1996]

- Dante Alighieri, The Divine Comedy: Hell, Purgatory, Heaven, A Terza Rima Version by Peter Dale, London, England, Anvil, 1996.

\section{Elio Zappulla [1998]}

- Dante Alighieri, Inferno, Translated into English Verse with Notes and an Introduction by Elio Zappulla, Illustrated by the Paintings of Gregory Gillespie, New York, Pantheon Books, I998.

\section{W.S. Merwin [2000]}

- Dante Alighieri, Purgatorio, A New Verse Translation by W.S. Merwin, New York, Alfred A. Knopf, 2000.

Robert and Jean Hollander [2000, 2003]

- Dante Alighieri, Inferno, Translated by Robert \& Jean Hollander, Introduction \& notes by Robert Hollander, New York, Doubleday, 2000. 
- Dante Alighieri, Purgatorio, A Verse Translation by Jean Hollander \& Robert Hollander, Introduction \& notes by Robert Hollander, New York, Doubleday, 2003.

Michael Palma [2002]

- Dante Alighieri, Inferno, A New Verse Translation by Michael Palma, New York, W.W. Norton \& Company, 2002.

Anthony Esolen [2002]

- Dante Alighieri, The inferno, translated, edited, and with an introduction by Anthony Esolen, illustrations by Gustave Doré, New York, Modern Library, 2002

\section{Bibliography of Dutch Translations of Dante's Divine Comedy}

\section{A.S. Kok $[1863,1864]$}

- Dantés Divina Commedia, Metrische vertaling, voorzien van ophelderingen en afbeeldingen, Door A.S. Kok, Haarlem, A.C. Kruseman, 1863-1864, 3 vols.

Dr. J.C. Hacke van Mijnden [1867, 1870, I873]

- De Komedie van Dante Alighieri, In dichtmaat overgebracht door Dr. J.C. Hacke van Mijnden, lid van den Raad van Bestuur der Koninklijke Akademie van Beeldende Kunsten te Amsterdam, Haarlem, A.C. Kruseman, 1867-1873, 3 vols.

U.W. Thoden van Velzen [1874]

- De Goddelijke Comedie van Dante Alighieri, I. De Hel (II. Het Vagevuur / III. Het Paradijs), met schets van den inhoud, verklaring en aanteekeningen, door U.W. Thoden v. Velzen, Naar het origineel bewerkt, Leeuwarden, A. Jongbloed, 1874, 3 vols.

- The first canticle had been published already in I870 (Leeuwarden, A. Akkeringa).

J.J.L. ten Kate [1876]

- De Hel van Dante Alighieri, In de dichtmaat van 't oorspronkelijke vertaald door J.J.L. ten Kate, met platen van Gustave Doré, Leiden, A.W. Sijthoff, 1876.

Mr. Joan Bohl [1876, I880, I884]

- Dante Alighieri, De Goddelijke Komedie, In Nederlandsche terzinen vertaald met verklaringen en geschiedkundige aanteekeningen nopens den dichter door Mr. Joan Bohl, Advocaat te Amsterdam, Eerste Lied: De Hel, Haarlem, W.C. de Graaff, 1876

- Tweede Lied: Het Vagevuur, Amsterdam, Brinkman en Van der Meulen, I880

- Derde Lied: Het Paradijs, Amsterdam, Brinkman en Van der Meulen, I884.

P.B. Haghebaert, S.Th.L., O.P. [190I]

- Het Goddelijk Spel van Dante Alighieri, In 't Vlaamsch vertaald en verklaard door P.B. Haghebaert, I: Van de Hel (II: Van het Vagevuur / III: Van den hemel), Leuven, I9OI, 3 vols.

J.K. Rensburg [1906, 1907, 1908]

- De Goddelijke Komedie van Dante Alighieri, Vertaald naar den oorspronkelijken tekst door J.K. Rensburg, Voorzien van verklarende noten en een levensbeschrijving van den dichter, Platen van Gustave Doré, Amsterdam, Vennootschap Letteren en Kunst, 3 vols. [1906, 1907, 1908]

Dr. H.J. Boeken [1907, 1909, 1910]

- Dante's Hel (Louteringsberg / Paradijs), in proza overgebracht en met een inleiding voorzien door Dr. H.J. Boeken, Amsterdam, Wereldbibliotheek, Onder leiding van L. Simons, Uitgegeven door: De Maatschappij voor goede en goedkoope lectuur, 3 vols. [1907/1909/1910] 
M.C.L. L[oman] [1908]

- De Hel. Eerste der drie gezangen: Hel, Vagevuur en Paradijs, tezamen uitmakende de Goddelijke Komedie van Dante Alighieri, uit het Italiaansch vertaald [door M.C. Loman,] onder toezicht van den Heer Nicola Aphel, professor te Amsterdam in de Italiaansche taal en letterkunde van de Universiteit te Modena [Bussum, 1908].

A.H.J. van Delft [1920, 192I]

- Dante-Verklaring, met vertaalden tekst door A.H.J. van Delft, Deel I: Goddelijke Komedie, Hel (Vagevuur/Hemel), Bussum, N.V. Uitgevers Maatschappij voorheen Paul Brand, 3 vols., 1920 (1920/192I).

Albert Verwey [1923]

- Dante Alighieri, De Goddelijke Komedie, Vertaling in terzinen door Albert Verwey, Haarlem, H.D. Tjeenk Willink \& Zoon, 1923.

P. Fr. C. Kops, O.F.M. [1929, 1930]

- Dantés Goddelike Komedie, vertaald door P. Fr. C. Kops, O.F.M., Amsterdam, N.V. Uitgeverij Joost van den Vondel, 3 vols. [1929, 1930] (part of this edition, however, bears the imprint 'Uitgeverij De Torentrans, Utrecht')

Betsy van Oyen-Zeeman [1932]

- Dante Alighieri, De Goddelijke Komedie, Vertaald door Betsy van Oyen-Zeeman, met eene inleiding van B.H. Molkenboer, O.P., Haarlem, H.D. Tjeenk Willink \& Zoon N.V., I932.

\section{Frederica Bremer [194I]}

- Dante Alighieri, De Hel (De Louteringsberg / Het Paradijs), Nederlandsche vertaling door Frederica Bremer, Met inleidende verklaringen naar aanteekeningen van Wilhelmina Kuenen, Haarlem, H.D. Tjeenk Willink \& Zoon N.V., I94I, 3 vols.

Frans van Dooren [1987]

- Dante Alighieri, De goddelijke komedie, vertaald, ingeleid en toegelicht door Frans van Dooren, Baarn - Amsterdam, Uitgeverij Ambo bv - Athenaeum-Polak \& Van Gennep, 1987.

\section{Jacques Janssen [1999]}

- Dante Alighieri, Mijn komedie. Deel I: Hel, Vertaald, ingeleid en geannoteerd door Jacques Janssen, Nijmegen, Sun, 1999.

\section{Ike Cialona and Peter Verstegen [200o]}

- Dante Alighieri, De goddelijke komedie, Met alle prenten van Gustave Doré, Vertaald door Ike Cialona en Peter Verstegen, Amsterdam, Athenaeum-Polak \& Van Gennep, 2000, 2 vols., vol. I (translation), vol. 2 (Italian text and commentary).

Rob Brouwer [2000, 200I, 2002]

- Dante Alighieri, De goddelijke komedie. Deel I: Inferno, Vertaald door Rob Brouwer, Met een inleiding door Ronald de Rooy, Leiden, Primavera Pers, 2000

- Dante Alighieri, De goddelijke komedie. Deel II: Purgatorio, Vertaald door Rob Brouwer, Leiden, Primavera Pers, 200I

- Dante Alighieri, De goddelijke komedie. Deel III: Paradiso, Vertaald door Rob Brouwer, Leiden, Primavera Pers, 2002. 


\section{Index of names}

\section{Divine Comedy, citations from}

Inferno I, illustration I by Monika Beisner I

Inferno I, vV. I-6: 36, 38-4I, 5I, 53

Inferno 2, vv. 33-35: 25

Inferno 2, vv. 3-5: 24

Inferno 5, vv. IO6-I08: 45, 46

Inferno 9, vv. 6I-63: 8I

Inferno IO, vv. 25-27: IIO

Inferno I3, v. II5: 68

Inferno I7, vv. 98-I08: 37-40

Inferno 21, vV. I27-I32: 54

Inferno 22 illustration 2 by Monika Beisner II

Inferno 22, v. $32: 69$

Inferno 24, vv. I-I8: 47, 48

Inferno 24, v. 69: 68

Inferno 25 illustration 3 by Monika Beisner III

Inferno 25, vv. I30-I4I: 65-68

Inferno 25, vv. 58-69: 60-64

Inferno 25: 68-7I

Inferno 26 illustration 4 by Monika Beisner IV

Inferno 26, Vv. II2-I2O: I4-20

Inferno 34, vv. I-3: 108, I09

Purgatorio 22, vv. 67-72: III-II3

Purgatorio 26 illustration 5 by Monika Beisner V

Purgatorio 26, vv. II2-II7: 34

Purgatorio 26, vv. II2-I26: 32, 33

Purgatorio 30, vv. 7-9: 50

Purgatorio 3I illustration 6 by Monika Beisner VI

Purgatorio 31, vv. 98-99: 107

Purgatorio 33, vv. I-3: 107

Purgatorio 33, illustration 7 by Monika Beisner VII

Paradiso I, vv. I-4: 30, $3 \mathrm{I}$

Paradiso I4 illustration 8 by Monika Beisner VIII

Paradiso I4, vv. 37-60: 26, 27, 29

\section{Convivio, citations from}

Convivio I, VII, I4 55, IO2

Convivio I, X, IO III
Ahern, John 43, II9

Ardizzone, Maria Luisa II7

Arnold, Bas I23

Asser, Jan I23

Auden, W.H. 7

Barolini, Teodolinda II7

Beisner, Monika 133

Berg, J. I23, I25, I26

Bergin, Thomas Goddard 30, 44, II8, I37

Bertran de Born 54

Bickersteth, Geoffrey 44, I37

Binyon, Laurence I8, I9, 44, II6, II7, I36

Blake, William 43

Boccaccio, Giovanni 75, IOI, I23, I29

Boeken, Hein 77, 78, 82, 86-87, 9I-93, 95, I27, I39

Bohl, Joan 76, 77, 79, 85-86, 9I-94, I26, I39

Bosco, Umberto 122

Boyd, Henry 43, II9, I35

Bremer, Frederica 77-79, 89, 9I-93, 96, I27, I28, I40

Brouwer, Rob 8, I2, I3, I5, I6, 77-80, 83, 89, 9I-93, 97, IOI, IO5-IIO, II2, II3, II6, I23, I29, I3O, I4O

Cachey, Theodore J. I9, 57, II7, I2I, I22

Carlyle, John 43, I35

Cary, Henry Francis 7, 43, II5, II9, I35

Cherchi, Paolo 9, Io, I33

Chiamenti, Massimiliano I06-IO9, III-II3, I3O

Chiavacci Leonardi, Anna Maria III, I22, I3O

Cialona, Ike 8, I2, I3, I7, I9, 20, 77-80, 82, 89, 9I-93, 97, IOI, IO4, IO5, IO7-IIO, II2, II3, II6, II7, I23, I28-I3O, I4O

Ciardi, John 9, 3I-34, 44, 45, II8, I37

Cohen, J.L. I23, I24

Conrad, Joseph 7

Contini, Gianfranco II2

Cotter, James Finn 8, 44, I2I, I38

Crespo, Angel I2I

Cummins, Patrick 30, 3I, II8, I36

Cunningham, Gilbert F. 23

D'Haen, Christine II7

Dale, Peter 8, 9, II, I3, 44, 56, 58, 6I, 63, 67, 69-72, II8, I2O-I22, I38

Dartmouth Dante Project I34 
De Glas, F. 124

De Meijer, Pieter I2, II6, I34

De Regt, Evelyn I24

De Rooy, Ronald 80, I05, II6, II7, I29, I34

De Sua, William 23, 34, II5, II7, II8, I2I, I35

De Villena, Enrique I23

Denissen, Frans II7

Doré, Gustave 76, 82, I04, I24

Du Toit, Delamaine A.H. I24

Durling, Robert 8, I2-I5, 4I, 43, 58, II5, II6, II9, I2I, I38

Eliot, T.S. 7, 9, 30, 33, 55, 57, 58, I2I

Ellis, Steve 8, 44, I2O, I2I, I38

Esolen, Anthony 8, 43, 44, II9-I2I, I39

Esposito, Enzo I23

Eyck, Charles 82

Febrer, Andreu I23

Fens, Kees II7

Flaccus Illyricus, Mathias I26

Fletcher, Jefferson Butler 30, 33, 34, 39, II8, I36

Francesca da Rimini (Inferno 5) 45, 54

Francescato, Giuseppe I23

Frost, Robert I22

Fubini, Mario II2

Fumagalli, Maria Cristina II5

Geryon (Inferno I7) 37-40

Giotto 82

Gmelin, Hermann 83

Gozzano, Guido Gustavo 64

Grandgent, Charles 7

Hacke van Mijnden, Jan Conrad 76, 77, 79, 8I, $82,84,85,9 \mathrm{I}-94, \mathrm{I} 24-\mathrm{I} 26, \mathrm{I} 39$

Haghebaert, P.B. 76, 78, 86, 88, 9I-93, 95, I26, I39

Halpern, Daniel 56, II9-I2I

Hauvette, Henri 83

Havely, Nick IIS

Hawkins, Peter S. II5, II6, I2O, I3O

Heaney, Seamus 7, 55, 56, 59, I2I, I22

Hirsch, Edward 122

Hollander, Jean 8, IO, II, I3, I5-I7, 4I, 44, 46, 56, 58, II5, II6, II9-I22, I33, I38

Hollander, Robert 7, 8, IO, II, I3, I5-17, 4I, 44, 56, 69, II5, II6, II9-I22, I33, I38

How, Louis 30, 34, II8, I36

Hudig, Judy I23
Jacoff, Rachel II5, II6, I20, I30

Janssen, Jacques 8, I2-I5, 77, 8I, 83, 89, 9I-93, 97, IOI-IO5, IO8-IIO, II6, I28, I29, I4O

Johnson, Henry 29, II8, I36

Joyce, James 7

Keats, John 43, 52

Keuls, H.W.J.M. 123

Kilmer, Nicholas 8, 44, I2I, I38

Kloos, Willem 86

Kok, Abraham 78, 79, 8I, 83-84, 9I-94, I25, I39

Kops, Christinus 76-78, 82, 87-89, 9I-93, 96, 98-99, I27, I28, I4O

Kruseman, A.C. I24-I26

Kuenen, Wilhelmina I28

La Piana, Angelina 23, II5, II7

Langdon, Courtney 30, II 8, 136

Lansing, Richard H. I2O, I29, I3O

Leek, Robert H. I25

Lo Cascio, Vincenzo I23

Logister, Wiel IoI, I29

Loman, M.C.L. 77, 78, 91-93, 95, I24, I40

Longfellow, Henry Wadsworth 7, 9, 24, 25-30, 43, 53-54, II5, I2O, I26, I35

Lowell, James Russell 7

Lowell, Robert 7

Lowry, Malcolm 7

Lucan 60, 7I

MacLeish, Archibald 122

Mandelbaum, Allen 8, 38, 39, 44, II9, I2I, I37

Mandelstam, Osip 55, I03, I30

Martinez, Ronald L. 4I, II5, II6, II9, I2I

Meijer, Jaap I27

Melville, Herman 43

Merrill, James I2O, I2I

Merwin, W.S. 7, 8, I3, 44, 56, 58, II6, I2O-I22, I38

Milton (Miltonian pentameter) 38

Molière 45, 60

Molkenboer, B.H. I25

Montale, Eugenio 55

Morraye, M.R. I23

Musa, Mark 8, 9, 35-39, 44, 53, II8-I2I, I37

Nauta, Lodi I23, I29

Newmark, Peter I06, I30

Nord, Max I27

Norton, Charles Eliot 7, 9, 24, 25, 28-30, I35 
Okey, Thomas 43, I35

Oldcorn, Anthony I22

Osherow, Jacqueline 120

Ovid 6o, 7I

Palma, Michael 8, II, I3, I7, I9, 43, 44, 56, 58, 59, 6I, 64, 67-72, II6, II7, II9, I20, I22, I39

Parsons, Thomas William 7, 9, 24, 25, 28, II5, I35

Pasolini, Pier Paolo I2I

Pearl, Matthew II5, I20

Perna, Michael I2I

Peternolli, E. 123

Petrocchi, Giorgio 44, 68, 80, I05, II9, I30

Pézard, André 83

Phillips, Tom 8, 44, I2I, I38

Pinsky, Robert 8, 9, II, I3, I7-I9, 39-4I, 44, 46, 5I, $52,56,58,59,62-64,66,68-73$, II 6, II 7, II 9 , I2O, I22, I38

Pound, Ezra 7, 9, I8, 30, 33, 55, II7

Princeton Dante Project 46, I34

Racine, Jean 45, 60

Reggio, Giovanni 122

Rensburg, Jacques Karel 77, 82, 86, 9I-93, 95, I26, I39

Reynolds, Barbara 44

Rijser, David II7

Roddwig, M. I26

Rogers, Charles 43, II9, I35

Santayana, George 7

Sapegno, Natalino 80, I25

Sayers, Dorothy 44, 57, 58, 62, I21, I22, I36

Shelley, Percy Bysshe 52, 56

Sinclair, John D. IO, II, 43, 46, 48, II5-II6, I36

Singleton, Charles 9, I2, I3, I5, 34, 35, 4I, 43, 46, 58, 7I, 83, II5-II6, II8, I2I, I37

Sisson, C.H. 8, 44, I2I, I22, I38

Slade, Carole Ann IIs

Statius III

Sterenborg, J. I23

Tate, Allen I22

Tellegen, Toon IOI, I29

Ten Kate, Jan Jacob Lodewijk 76, 78, 82, 85, 9I-94, I24-I26, I39

Terlingen, Jan H. I23, I25-I27
Thoden van Velzen, Ubbo Wilhelm 76-78, 82, $84-85$, 9I-94, I39

Thomas, Edward 122

Torrens, James 8, 44, I2O, I2I, I38

Ugolino (Inferno 33) 54

Ulisse (Inferno 26) I3-2I, 54, 72, 73, I22

Uyldert, M. I25

Van Deel, Ton II7

Van Delft, Antonius Henricus Josephus 78, 80, $87,9 \mathrm{I}-93,96, \mathrm{I} 23, \mathrm{I} 25, \mathrm{I} 4 \mathrm{O}$

Van Dooren, Frans 8, I2, I3, 77-79, 8I, 83, 89-93, 97, II6, I23-I25, I27-I29, I40

Van Dooren, Kees 123

Van Duinkerken, Anton I25

Van Heck, Paul 9, IO, II6, I23, I33

Van Oyen-Zeeman, Betsy 78, 89-93, 96, I40

Van Suchtelen, Nico I23

Van Tienhoven, G. I25

Vandelli, Giuseppe 80, I25

Vanni Fucci (Inferno 24-25) 59, 68

Verstegen, Peter 8, I2, I3, I7, I9, 20, 77-80, 82, 89-93, 97, IOI, IO4, IO5, IO7-IIO, II2, II3, II6, II7, I29, I3O, I4O

Verwey, Albert I2, 77, 80, 83, 87, 9I-93, 96, I04, II5, I25, I3O, I4O

Vincent, Marvin Richardson 29, 136

Virgil 54, 8I, III, II2

Voorvelt, C.P. 88, I27

Vossler, Karl 83

Walcott, Derek 7, I2I

Wallace, David IIs

White, Lawrence Grant 30, II8, I36

Wicksteed, Philip 43, I28, I35

Wijdeveld, Gerard 87-89, 99, I27, I28

Wilbur, Richard II, 20, 45, 52, 56, 58-64, 66, 6873, II9, I22

Wilmer, Clive I20

Witte, Karl 80, 83

Wlassics, Tibor 68, I22

Yeats, William Butler 39

Zappulla, Elio 8, 44, I2O, I2I, I38

Zimmerman, Seth I2I 



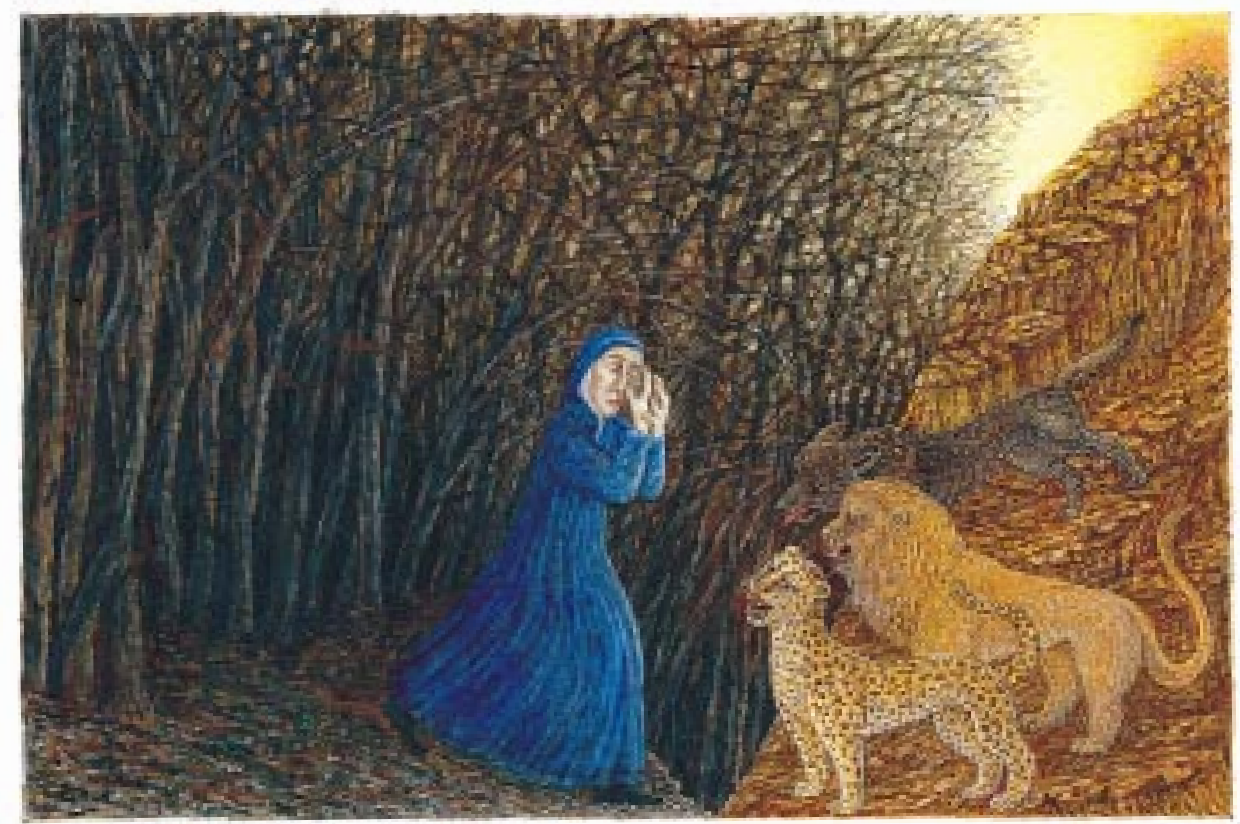

\section{INFERNO I $(\mathrm{I} 5 \times$ IO $\mathrm{cm})$}

Dante, having lost his way, tries to escape from the dark wood. While climbing a hill, he encounters a leopard, a lion and a she-wolf. 


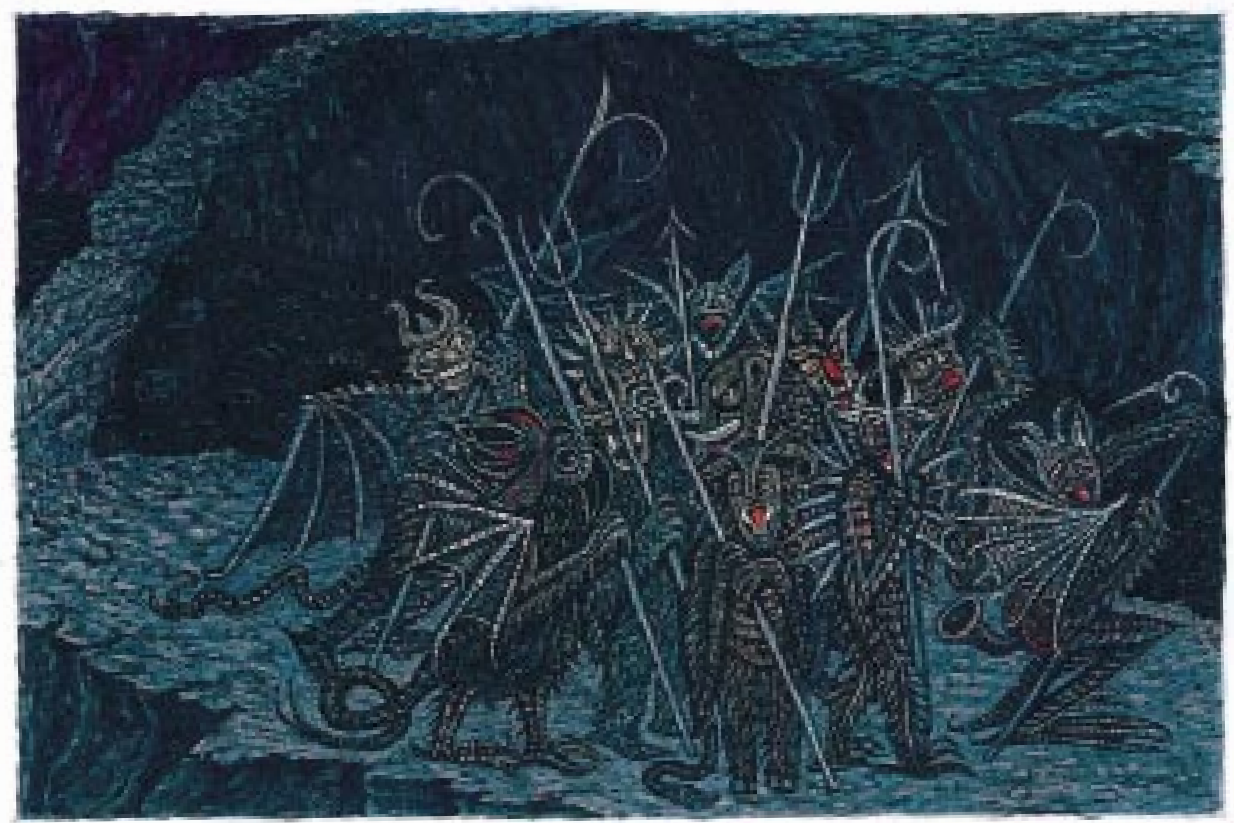

2. INFERNO $22(\mathrm{I} 5 \times$ IO $\mathrm{cm})$

The real protagonists of the bolgia of the barrators are the guardians, a bunch of frightening, sadistic and stupid devils. Dante calls them Malebranche ('Evil Claws') and links their representation closely to popular medieval culture. 


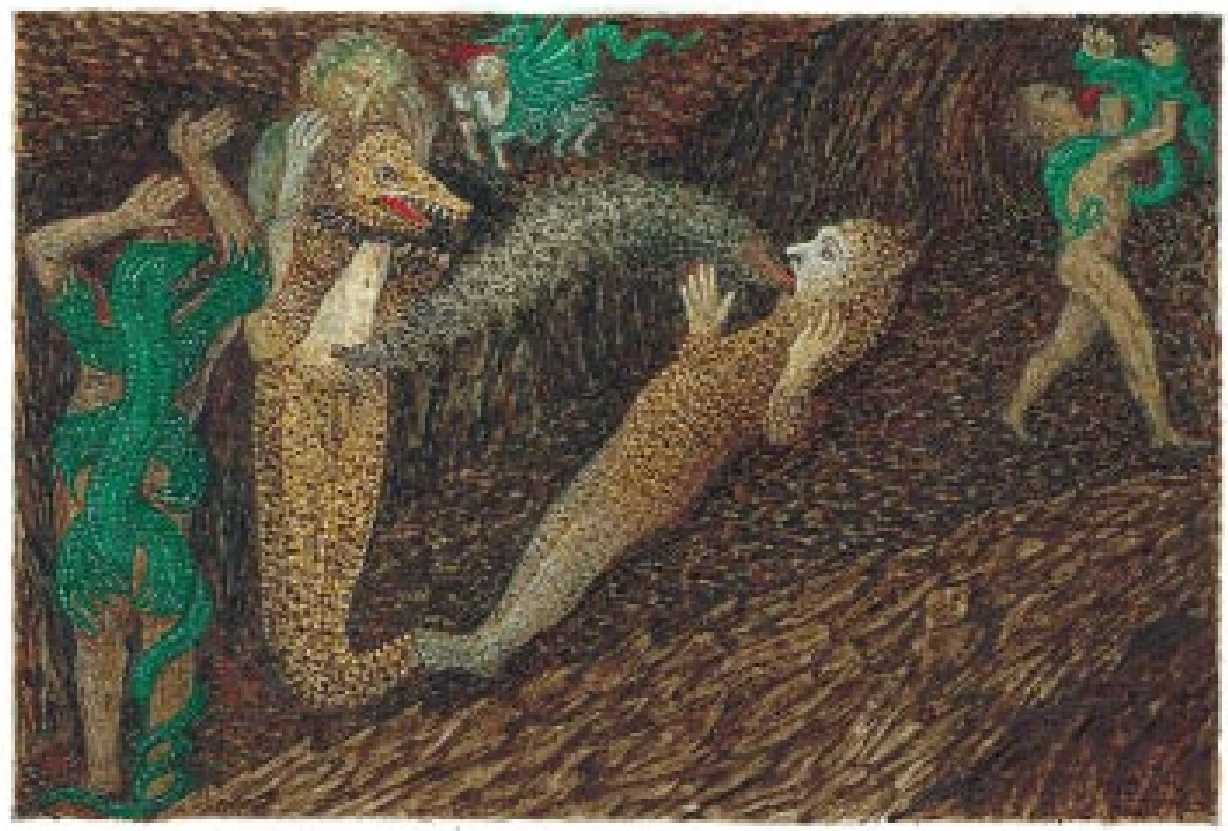

3. INFERNO $25(15 \times 10 \mathrm{~cm})$

In the bolgia of the thieves, Dante tries to emulate Ovid's and Lucan's metamorphoses.

In the image, from left to right, we see four scenes: I) Agnello turns into a hybrid creature after a horrible embrace with a serpent (Cianfa), 2) the transmutation of a serpent (Francesco) and a man (Buoso), 3) the centaur Cacus with a dragon and snakes on his shoulders, and 4) Vanni Fucci, who makes an obscene gesture to God while serpents are already tying his hands. 


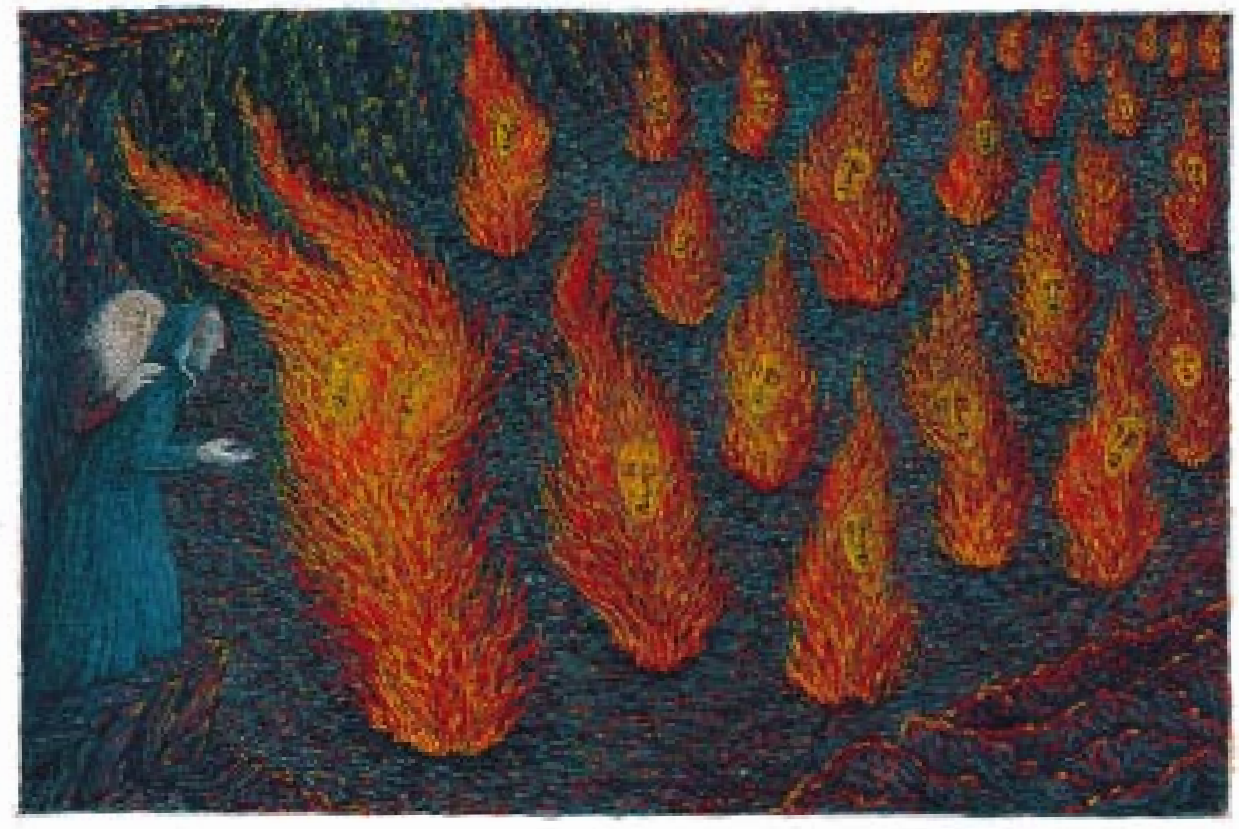

4. INFERNO 26 ( $15 \times$ IO cm)

The false counselors of the eighth bolgia are engulfed in flames. In the double flame are two inseparable Homeric heroes, Ulysses and Diomedes. Dante is eager to hear about Ulysses' death. 


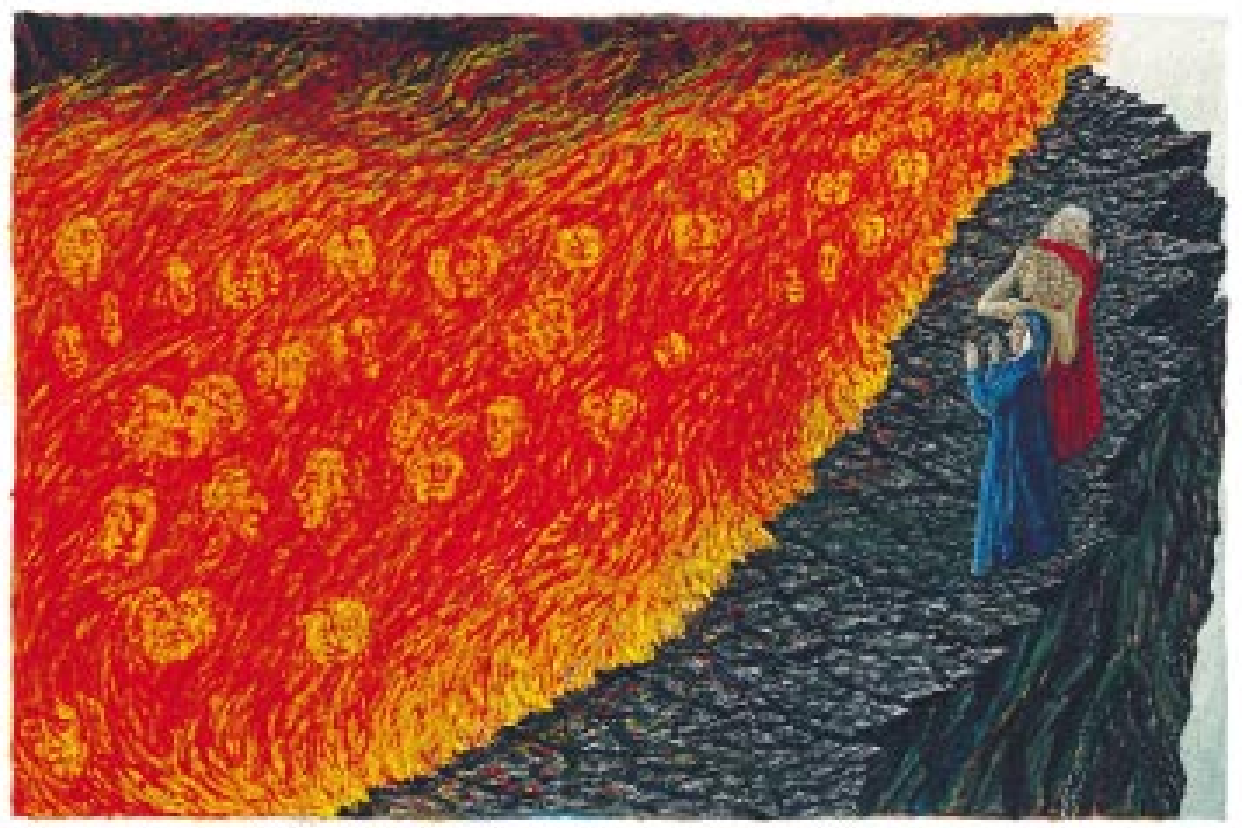

5. PURGatorio 26 ( $15 \times$ IO $\mathrm{cm})$

On the seventh and last terrace of Purgatory, Dante meets the lustful, who are purified inside a fire. Among these lustful are several poets. Dante talks about poetry with his 'father' in poetry, Guido Guinizzelli. The Provençal poet Arnaut Daniel speaks the last tercets of the canto in his mother tongue. 


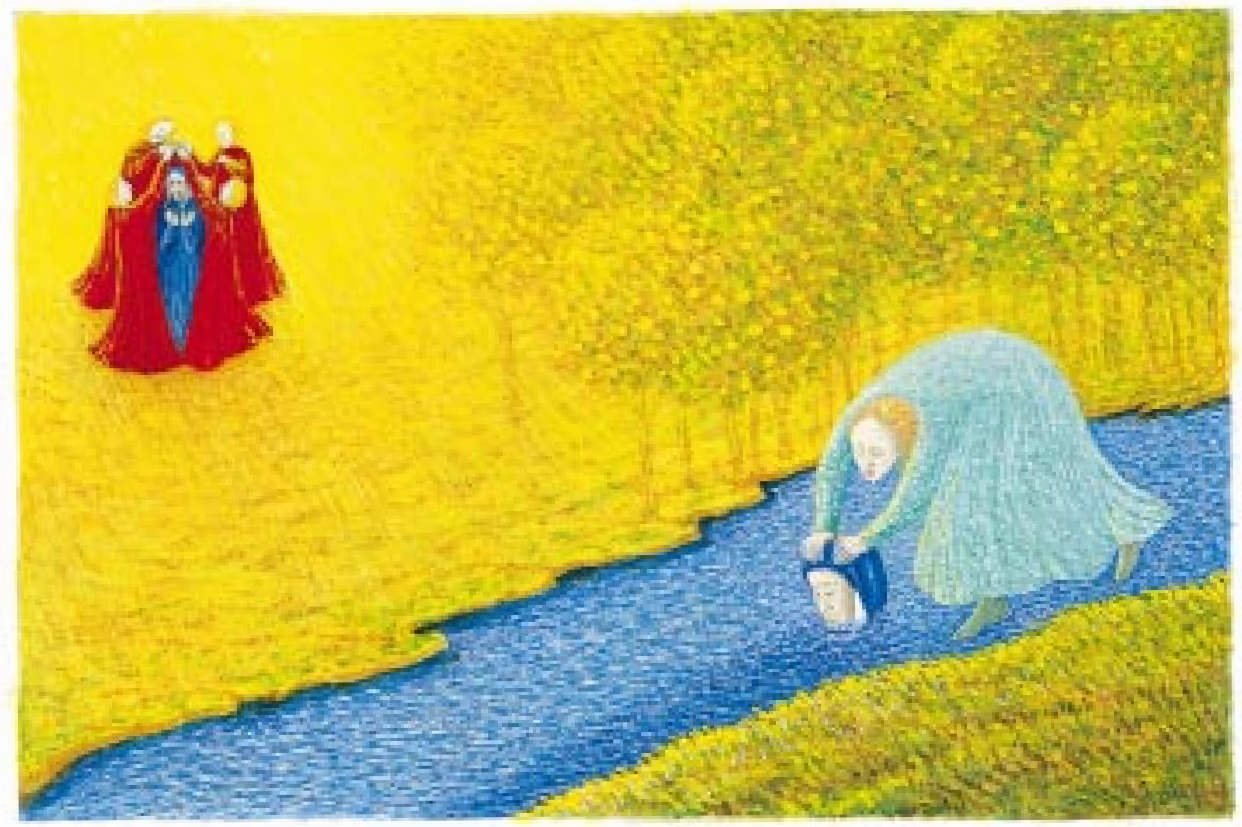

6. PURGATORIO 3 I ( $15 \times$ IO $\mathrm{cm})$

Dante has reached the Garden of Eden, situated on top of Mount Purgatory. Sighing and weeping, Dante confesses his disloyalty to Beatrice. Having shown remorse, Matelda submerges Dante in the river Lethe and he drinks its water. Matelda pulls Dante on to the riverbank, where he dances with four nymphs, personifications of the four cardinal virtues and stars in heaven. 


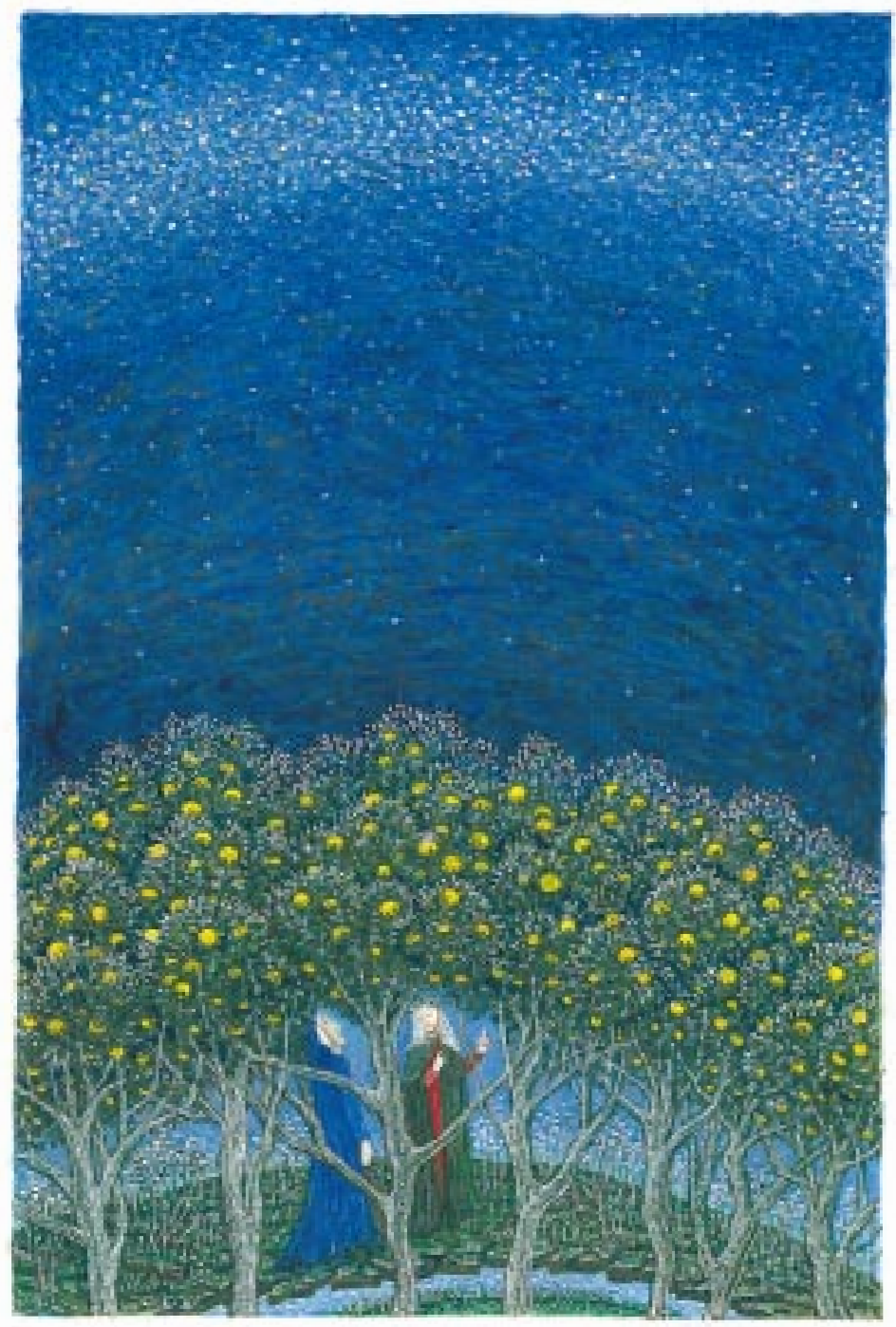

\section{PURGATORIO $33($ IO $\times 15 \mathrm{~cm})$}

Totally renewed and purified, Dante is ready to mount up to the stars together with Beatrice. 


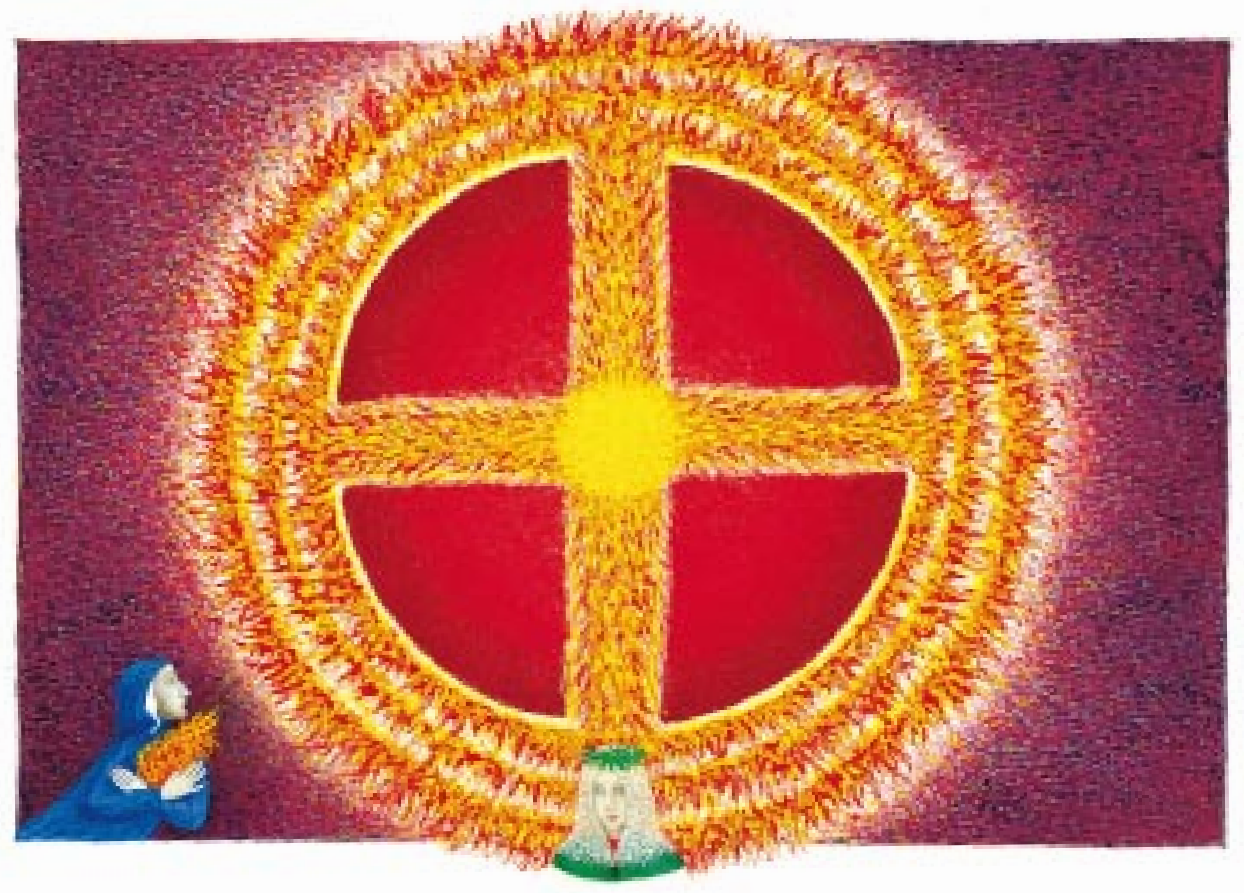

\section{PARADISO I4 ( $15 \times$ IO $\mathrm{cm})$}

Entering the Heaven of Mars, Dante sees a circle and a Greek cross of moving lights, the spirits of warriors and martyrs of the faith. Among these blessed spirits, Dante will meet his own great-great-grandfather, the crusader Cacciaguida. 